\title{
The role of New Zealand endemic lizards in Salmonella transmission in the takahē translocation network
}

Shanna Patricia Rose

A thesis submitted in partial fulfilment of the requirements for the degree of Master of Science

Victoria University of Wellington

Te Whare Wānanga o te Ūpoko o te Ika Māui

2015 


\section{Abstract}

The dynamics of disease in wildlife populations often involve a complex relationship between physiological, environmental and ecological variables. Defining the pattern of pathogen infection between primary hosts, sympatric species and their environments is crucial in the understanding of potential impacts a pathogen may have on its host species. Very little is known about pathogens of native, New Zealand wildlife. Understanding the role pathogens play in structuring communities is crucial in the conservation of threatened New Zealand wildlife species. Salmonella is an important pathogen of reptiles, birds and mammals, and Salmonellosis has caused significant mortality in wildlife around the world. Recently, Salmonella has been isolated from takahē from a private island in the takahē translocation network. Reptiles have been implicated as asymptomatic carriers and transmitters of Salmonella, and lizards from a private (undisclosed) island have been implicated in the transmission of Salmonella to takahē. To investigate the capacity for lizards to act as a Salmonella reservoir in the takahē translocation network, I examined the distribution, abundance and Salmonella prevalence of lizards within takahē territories on the private island and on Maud Island where takahē also reside. Additionally, I investigated the presence of Salmonella in soil and water samples from takahē territories on the private island, Maud Island and at the Burwood Bush takahe rearing facility. Lizard densities on the private island were estimated to be between 466-6020 lizards/ha, and 118-1528 lizards/ha on Maud Island. Salmonella serovars concurrent with those isolated from takahē were isolated from $2 \%$ of lizards, $25 \%$ of water and $50 \%$ of soil samples on the private island, indicating that lizards and the environment play an important role in transmission and maintenance of Salmonella to takahē. Salmonella was not isolated from lizards or environmental samples on Maud Island or at Burwood Bush, indicating prevalence too low to detect in this study or a Salmonella reservoir unique to the private island. Further investigation of Salmonella sources; serovars and seasonal patterns of Salmonella infection is needed to better inform takahē translocation actions on the private island. Additionally, further examination of Salmonella in lizards and the environment is necessary to assess the risk of Salmonella infection to takahē on Maud Island. 


\section{Acknowledgements}

First and foremost, a huge thank you to my primary supervisor, Nicola Nelson. Your support encouragement and advice over the last two years has been amazing. I am so grateful for the opportunity I was given to spend time on beautiful islands with incredible animals.

Thank you of course to my secondary supervisor Zoe Grange for her expert advice and for toiling with me on the private island.

Special thanks are necessary for David Clarke. Without you there would be no thesis.

And thank you to Penny Krafft, without whom I would have been writing this thesis on the streets.

Thank you to my able assistant Thomas Burns who provided much entertainment, hard work and beautiful photographs and thank you to the wonderful ladies of the office, Jo Carpenter, Patty Ramirez, Steph Price, Helen Taylor, Anna Carter and Emma Dent for all your support and advice.

Grateful thanks to Patricia Stein for her wonderful support and advice and thank you to Cathy Dowel for getting me through the last two years relatively unscathed.

Thanks to Nigel French and all the staff who helped me at the Hopkirk Research facility. Anne Midwinter, Angie Reynolds, Rukhshana Akhter, Lynn Rogers; I am forever in your debt.

I thank Ngāti Kuia and Ngāi Tahu for supporting my research and in particular, I would like to thank Sandra Cook and Cathy Onellion for their hospitality.

Sincere thanks to Phil Marsh, Chris and Linda Birmingham, Stuart Burbidge and Neo for your help on Maud Island and to Kira and Gilbert at Burwood Bush.

I am grateful for the financial support I received through the VUW graduate award, Centre for Biodiversity and Restoration scholarship and Allan Wilson Centre internship.

Finally, thank you to my wonderful family- Lea, Rob, Kathy, Sheridan, Krisna, Chelsea, Karl, Savannah, Brya, Charli and Felix- for all their unwavering support.

For Dad. 


\section{Table of contents}

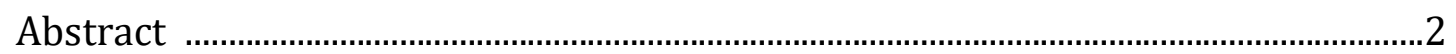

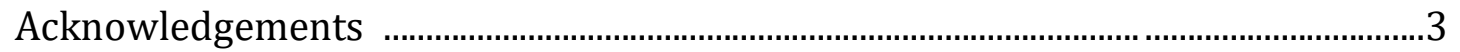

Table of Contents ................................................................................................................

Chapter 1: General Introduction .........................................................................................

Thesis aim and outline ..................................................................................................12

Chapter 2: Are New Zealand lizards abundant enough to support a Salmonella reservoir? .............................................................................................................

2.1 Introduction ........................................................................................................

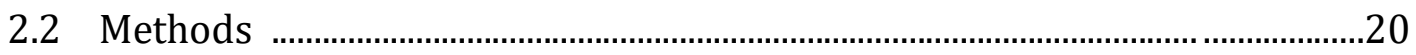

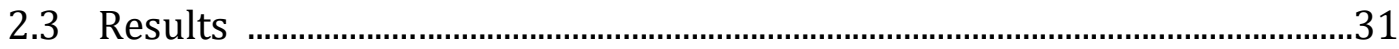

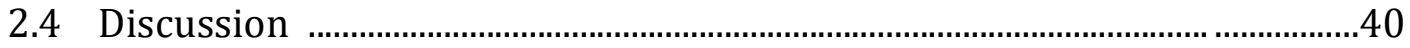

Chapter 3: Are skinks the Salmonella reservoir in the takahē translocation

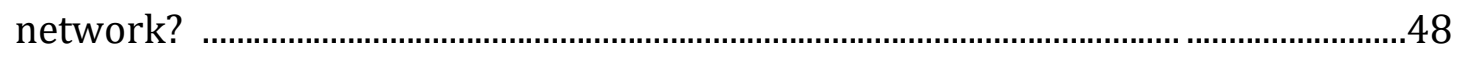

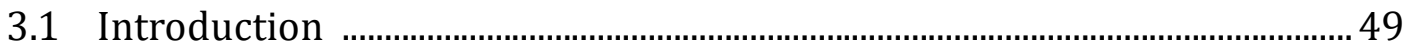

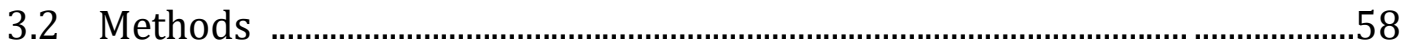

3.3 Results .........................................................................................................64

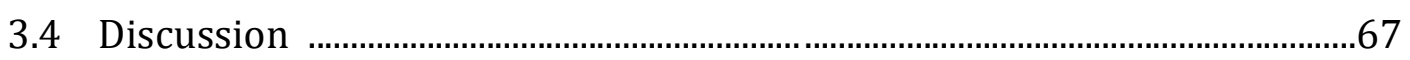

Chapter 4: Lizards play a role in Salmonella persistence and transmission to

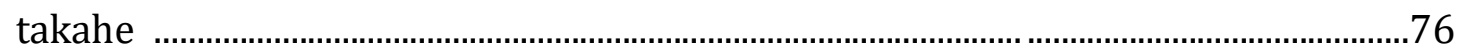

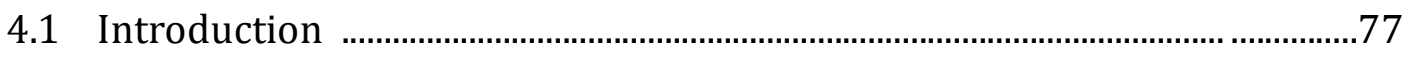

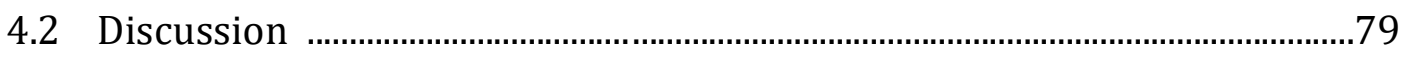

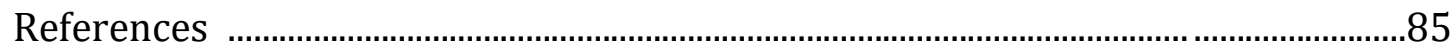


Chapter One: General Introduction 


\section{Wildlife disease ecology}

Infectious disease represents a substantial threat to endangered wildlife and has been implicated in significant declines of many species. For example, avian malaria and avian pox have been cited as one of the main drivers of species declines and extinctions of endemic Hawaiian avifauna (van Riper et al. 2002). Additionally, chitridiomycosis has caused the decline or extinction of over 1800 species of amphibians worldwide (Skerrat et al.2007) and canine distemper has caused the decline of the endangered black-footed ferret in the United States (Williams et al. 1988), African wild dogs in Kenya and the Serengeti (Alexander \& Appel 1994) and Caspian seals in the Caspian Sea (Kennedy et al. 2000). Despite numerous reports of the significant impacts disease can have on animal populations, historical conservation efforts have focused primarily on other drivers of species decline such as habitat loss and invasive species (Woodroffe 1999). However, wildlife disease has received increased attention in recent years, parallel to an apparent increase in disease emergence within threatened wildlife populations (Daszack et al. 2000). With the recognition of the important role infectious disease can play in structuring endangered wildlife communities, the need to develop methods to detect and manage disease threats has become apparent. Wildlife disease dynamics are influenced by complex interactions between host, pathogen and the environment and a combination of ecological and epidemiological perspectives could be key in understanding pathogen dynamics in wild life populations and communities (Holt et al. 2006; Lafferty \& Gerber 2002).

Understanding disease dynamics is particularly crucial for the conservation and management of threatened species. Pathogens can reduce fitness in wild hosts through decreased survival, increased risk of predation and low reproductive output (Johnson et al. 2006; Smith et al. 2008), factors that could have a significant impact on already threatened wildlife populations. Additionally, the development of reintroduction as a conservation management strategy in recent years has increased the connectivity of threatened wild life populations, thus amplifying the risk of disease transmission throughout translocation networks (Hess 1996). Reintroduction is the movement of animals to re-establish 
populations in their former natural range or to augment existing populations (Griffith et al. 1989) and in New Zealand alone there have been over 3000 official translocations of threatened animals for conservation purposes (Sherley et al. 2010). The inadvertent movement of any pathogens that are associated with translocated animals is inevitable and could pose a significant risk to animals already in residence at the site of translocation (Viggers et al. 1993). For example, avian malaria credited with the extinction and decline of endemic bird species in Hawaii is thought to have been co-introduced with domestic birds in the 1800 s (van Riper et al. 2002). Conversely, immunologically naïve animals that are translocated could be exposed to novel pathogens present in their new environment, as evidenced by mortality in three endangered kakapo (Strighops habroptilus) when exposed to the pathogenic bacteria Erysipelas rhusiopathiae during translocation in New Zealand (Gartrell et al. 2005). Additionally, stress associated with translocation could lower a target animal's immune function, potentially allowing any pathogenic organisms to manifest as disease (Teixeira et al. 2007). There is now an understanding of the important role pathogens can play in the success of reintroduction programmes, and disease risk assessment, screening and quarantine procedures are now routinely carried out during animal translocations (McInnes et al. 2004). However, documentation on wildlife disease in New Zealand remains sparse and disease risk assessments largely target known pathogens. Salmonella is one such targeted pathogen. Salmonella is an important bacterial pathogen with over 2500 described serovars (Mermin et al. 2004). Many of these serovars are host generalist and can infect a wide range of birds, reptiles and mammals (McClelland et al. 2001). Salmonellosis has been implicated in the morbidity and mortality in wild animal populations worldwide (McClelland et al. 2001).

\section{Salmonella in takahē}

In 2012 Salmonella houtenae and S. mississippi were isolated from the flightless, New Zealand endemic rail, the takahē (Porphyrio hochstetteri) from a privately owned island (this island can not be identified for security reasons) (Grange pers. Comm. 2015). These serovars had not previously been isolated from 
takahē despite routine disease screening for Salmonella species, indicating that the private island may harbour an environmental Salmonella reservoir. Additionally, one of the birds that had tested positive for Salmonella mississippi was moved to the Burwood Bush takahē rearing facility in Te Anau where it also tested positive for S. Saintpaul a week later. The isolation of S. Saintpaul from this bird could provide an indication that the takahē was infected with multiple Salmonella serovars from the private island; alternatively, it could indicate another source of infection at the Burwood Bush facility.

Takahē (Porphyrio hochstetteri) (Fig. 1) are endangered, flightless rails, endemic to New Zealand. Classified as Nationally Critical under the New Zealand Threat Classification System, the current population estimate stands at approximately 227 adult birds (Wickes et al. 2009). Due to habitat loss and pressure from introduced predators, small populations are now restricted to several offshore New Zealand islands, main land sanctuaries and one free-ranging population in Fiordland (Fig. 2).

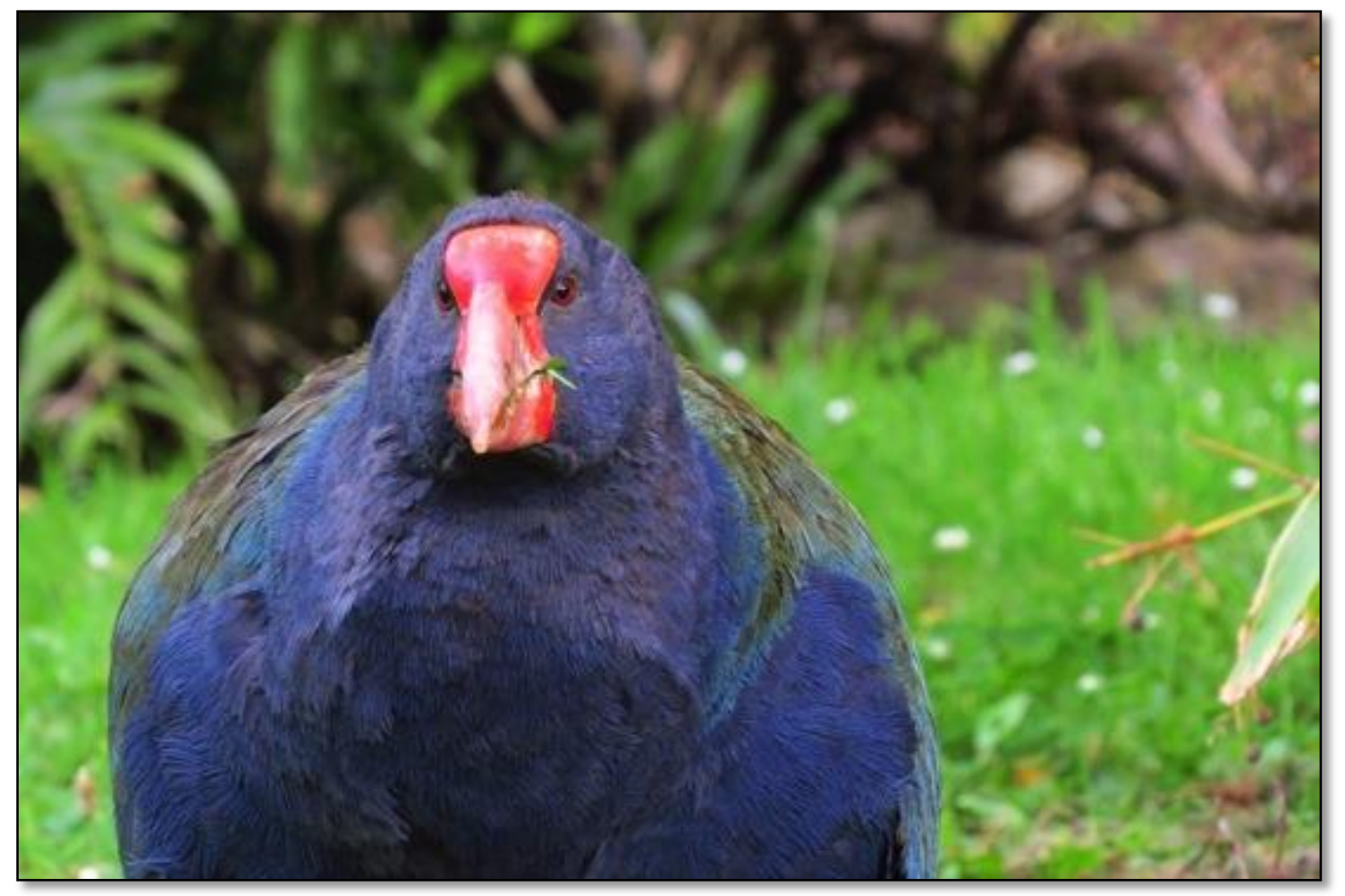

Figure 1: Adult takahē, Maud Island, Pelorus Sound (Photo S.Rose). 


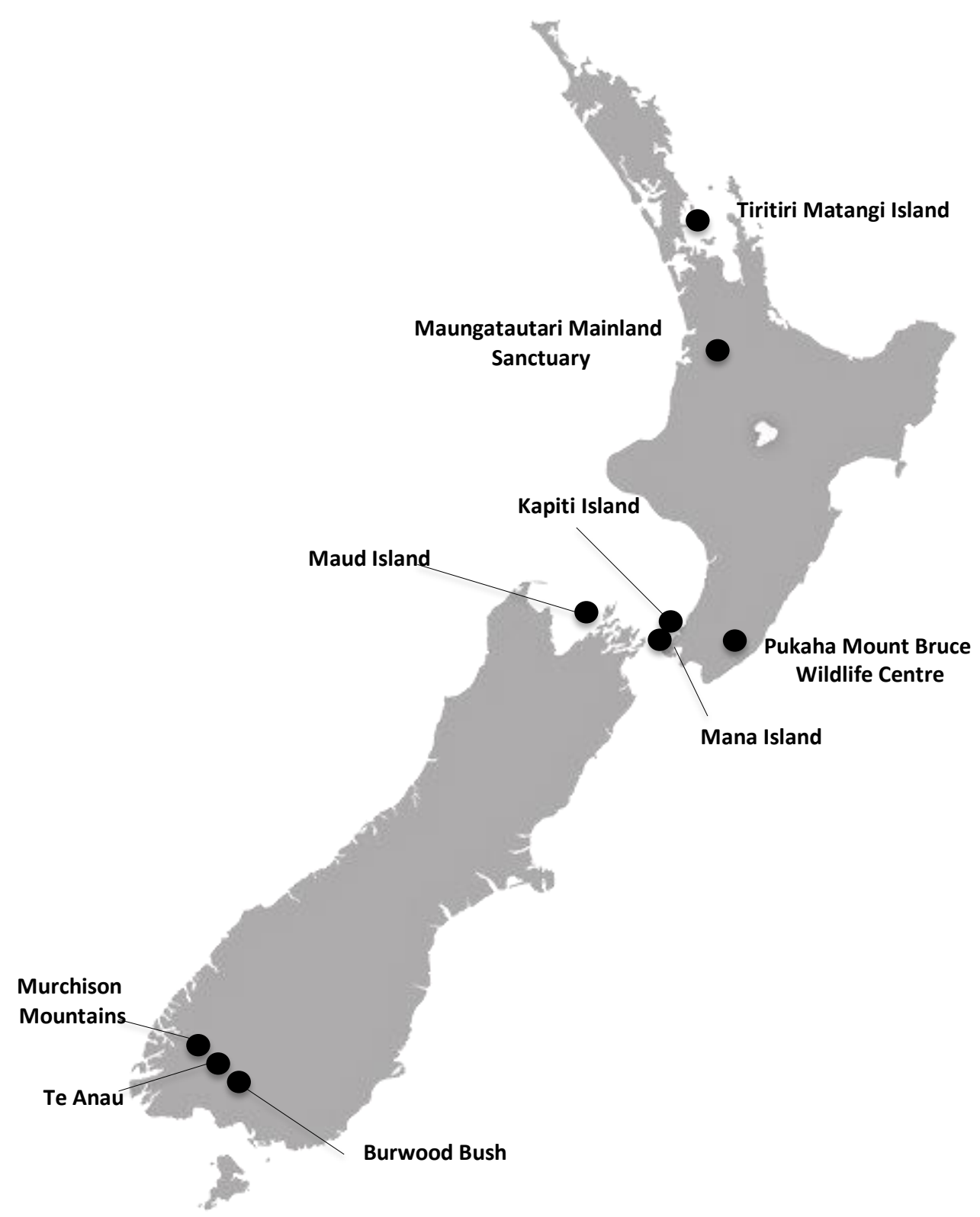

Figure 2: Map of New Zealand showing free-ranging populations of takahē (Murchison Mountains, five offshore islands and one mainland sanctuary) and captive populations of takahē (Te Anau, Burwood and Pukahaha Mount Bruce) (Wickes et al. 2009). Location of the privately owned Southland Island not disclosed for security reasons.

The remaining takahē population is intensively managed and individuals are regularly moved between these sites to retain as much genetic diversity as possible in the larger population and ensure breeding success (Jamieson \& Briskie 2006; Wickes et al. 2009). Birds are routinely screened for disease during the translocation process in order to mitigate disease outbreaks (McInnes et al. 2004), although disease detection is often limited due to inexact tests or difficult to detect diseases (Johnson-Delaney 1996). Birds selected for translocation are 
often quarantined at the Burwood Bush takahē rearing facility in Te Anau before being moved to other sites, making the Burwood Bush site an important hub in the translocation network (Grange et al. 2014).

Although the Salmonella infected takahē did not exhibit signs of clinical disease, Salmonella infection can remain asymptomatic in a healthy host, only presenting symptoms at times of stress (Pocock et al. 2001). It is not known how this infection might affect the birds in future, or what effect it might have on takahē and other species present at other sites within the takahē translocation network. Salmonella species are particularly prevalent in wild avian populations and Salmonellosis been associated with serious illness and mortality in several bird species including wild turkeys in Texas (Rocke and Yuill 1987), free-living passerine birds (Passeriformes) in the United States (Brittingham and Temple 1986; Hall and Saito 2004), England and Wales (Lawson et al. 2010) and New Zealand (Ewen et al. 2007). Despite a high number of documented Salmonella outbreaks in avian populations, the transmission and impact of this bacterium on wild avian hosts is poorly understood (Ewen et al. 2012). Many Salmonella serovars do not display host specificity, resulting in interspecies transmission and communities containing a complex web of multiple host species and environmental sources (Pocock et al. 2001). Additionally, asymptomatic carriage of Salmonella by some hosts can result in the maintenance of Salmonella reservoirs in an ecological system (Pocock et al. 2001), further confounding interpretation of disease transmission pathways. Very little is known about the animal community and species interactions on the private island making identification of potential Salmonella reservoirs difficult. However, takahē on the private island have been observed consuming lizards, presenting a possible source of Salmonella infection (Grange pers. comm. 2015).

Salmonella in lizards and the environment

Salmonella is often considered a commensal component of lizard gut fauna (Scheelings et al. 2011) and the ability of lizards to carry Salmonella infection whilst remaining asymptomatic is well documented (Hall \& Saito 2008; Onderka 
\& Finlayson 1985). Additionally, Salmonella mississippi and S. houtenae have recently been isolated from New Zealand endemic skinks and geckos (Baling et al. 2013; Middleton et al. 2011; Middleton et al. 2014), and lizards have been implicated as a possible reservoir for S. Saintpaul in sheep in New Zealand (McInnes 1971). However, a lack of fundamental ecological knowledge about lizard communities on the private island makes it difficult to understand the role they might play in Salmonella persistence and transmission of Salmonella to sympatric takahē. Furthermore, little is known about the ecology of lizards at other takahē translocation sites. For example, Maud Island in the Pelorus Sound is also host to a diverse community of skinks and geckos, and also hosts a population of takahē that are routinely moved throughout the takahē translocation network. Although Salmonella has not previously been isolated from lizards on Maud Island (Middleton et al. 2010), very little is known about lizard ecology at this site. Without basic ecological knowledge about the lizard communities within the takahē translocation network, it is difficult to assess the risk they might pose as Salmonella reservoirs to takahē. In addition to animal hosts, Salmonella has the capacity to survive for extended periods of time in the environment.

For example, Salmonella has been reported to maintain viability in soil for over 300 days (Holley et al. 2006), in fresh water for 115 days and in animal faeces for 30 months (Johnson \& Delaney 1996). The capacity for Salmonella to survive independently of a host allows infectious species of Salmonella to further exploit transmission strategies by increasing the likelihood of contact with potential hosts whilst still viable (Holley et al. 2006). Artificial water feeders are provided for takahē on the private island, Maud Island and the Burwood bush takahē rearing facility. These water feeders are congregation sites for takahē and sympatric species, increasing opportunities for Salmonella transmission via inter and intraspecific contact. Additionally, build-up of faecal material from Salmonella infected animals in and around these water sources could potentially result in environmental Salmonella reservoirs in the soil and water. 
The aim of this thesis was to investigate the ecology of lizard populations within the takahē translocation network and assess their role as potential Salmonella reservoirs for takahē. To do this, I investigated the ecology and Salmonella carriage of lizards living sympatrically with takahē on the private island, Maud Island and the Burwood Bush takahē rearing facility in Te Anau. In addition, I examined the prevalence of Salmonella in environmental sources within takahē territories at these three sites. The findings reported in this thesis will help to advance the understanding of disease processes occurring within the takahē translocation network and better inform takahē disease management strategies.

Chapters two and three are written as stand-alone manuscripts and as such, some repetition is inevitable. Chapter two describes the ecology of lizards within takahē territories on the private island and Maud Island with reference to the potential impacts these lizard populations could have on sympatric takahē. Chapter three describes Salmonella ecology in lizard populations and the environment within takahē territories on the private island, Maud Island and Burwood Bush takahē rearing facility.

Chapter four provides a synthesis of the main findings of this thesis and describes implications for the future management and conservation of lizards and takahē in addition to directions for future research. 
Chapter two: Are New Zealand endemic lizards abundant enough to support a Salmonella reservoir? 


\subsection{Introduction}

New Zealand is host to an extensive endemic reptile fauna comprised of over 100 lizard species from the families Gekkonidae and Scincidae, 60 of which are described, and the tuatara (Sphenodon) (Tingley et al. 2013). Due to habitat loss and pressure from introduced mammalian predators many New Zealand reptile populations have undergone significant decline in numbers and geographical range (Towns et al. 2001). Over one half of endemic New Zealand reptile species are now restricted entirely to predator free offshore islands (Towns \& Daugherty 1994 ) and nearly $75 \%$ of all species are considered threatened (Hitchmough et al. 2013). New Zealand reptiles are largely considered cryptic species making detection and monitoring of these animals problematic (Hoare et al. 2001; Towns \& Ferreira 2001), and monitoring lizard populations on remote offshore islands can prove logistically challenging to conservationists. As a result, there is dearth of knowledge regarding the demography, distribution, abundance and density of many New Zealand endemic reptile species.

Basic understanding of ecology is essential for the conservation of endemic New Zealand lizards and understanding distribution, habitat occupancy, activity periods and disease ecology, for example, are fundamental in informing conservation management and habitat restoration strategies (Neilson et al. 2006). For example, investigation of habitat use of the nationally threatened chevron skink (Oligosoma homalonotum) on Great Barrier Island, New Zealand found that stream habitats were of particular importance to this species (Nielson et al. 2006). This basic understanding of the chevron skink's resource use will ultimately inform management decisions such as suitable sites for translocation and habitat restoration of sites where the skinks occur. In addition, knowledge of the preferred habitat of the chevron skink enables targeted searching for this species in its known range (Nielson et al. 2006).

Baseline information of New Zealand lizard ecology can provide an indication of how introduced predators affect lizard populations, and how these lizard populations respond to subsequent management actions such as predator 
eradication. For example, a study of the effects of the pacific rat, kiore (Rattus exulans) on an island population of Duvaucel's gecko (Hoplodactylus duvaucelii) prior to and after kiore eradication, provides empirical evidence of the importance of baseline ecological knowledge of lizard populations in $\mathrm{New}$ Zealand (Hoare et al 2007). The kiore is a known predator and resource competitor of lizards (McCallum 1986; Towns 1996), and its introduction to New Zealand resulted in widespread changes to survival and distribution of native fauna (Worthy \& Holdaway 2002). Prior to kiore eradication, the population of $H$. duvaucelii on Ohinau Island was skewed towards larger individuals, and habitat use was largely restricted to coastal areas and high rocky outcrops (Hoare et al 2007). A survey of the $H$. duvaucelii population six months following kiore eradication found a change in habitat use, a significant increase in the number of smaller individuals captured and an increase in captures overall. The change in numbers, demographic structure and habitat use of $H$. duvaucelii subsequent to kiore eradication provide evidence that kiore were limiting juvenile recruitment to the population through predation, and changing the distribution of the geckos through a combination of predation and resource competition (Hoare et al. 2007).

Lizards and kiore coexisted on a privately owned island in Southland, New Zealand for many years until kiore were eradicated from the island in 1999 (this island is unable to be identified for security reasons and will be referred to as the "private island" for the purpose of this paper). However, without an existing inventory of lizard species on the private island and their demographic and geographic distributions prior to kiore eradication, it is impossible to know what effect kiore invasion and eradication has had on lizard populations. Comparison with other New Zealand islands where kiore have never been present suggests lizard diversity and abundance on the private island are likely to have suffered declines. Surveys of the lizard population on Lizard Island in the Hauraki Gulf found lizard detection rates were over 20 times lower after a kiore invasion of only one year (McCallum 1986). Middle and Green Islands in the Mercury island group avoided the introduction of mammalian predators and although they are comparatively small (13ha and 6ha respectively), the reptile fauna is comprised 
of 10 and seven species of lizard respectively and the tuatara (Towns et al. 1990). Similarly, a mouse (Mus musculus) incursion was detected in 2013 on Maud Island in Pelorus Sound, New Zealand, and attempted eradication of the mice by aerial poison drop was carried out in 2014 (Phil Marsh pers. comm. 2014). Maud Island is an important refuge for many endangered species including six species of lizard. However, no official inventory of lizard species and their distribution had previously been carried out on Maud Island, and so effects of the mouse incursion and subsequent eradication on resident lizard populations remain unknown.

Understanding New Zealand lizard ecology is not only important for the conservation of lizards but may be essential to the conservation of entire ecosystems. For example, the decline of Daphne rodriguezii, a perennial shrub endemic to the Balearic Islands in the Mediterranean, was attributed to the introduction of mammalian predators and subsequent extirpation of the frugivorous lizard Podarcis lilfordi (Traveset \& Riera 2005). The lizard was the only disperser of Daphne rodriguezii seeds and in its absence; the threatened shrub is facing extinction (Traveset \& Riera 2005). Fruit also constitutes an important dietary component for many New Zealand lizard species (Whitaker 1987). Analysis of gut content of W. maculatus at Turakirae Head in Wellington found up to $65 \%$ of animals had consumed fruit from Coprosma and Muehlenbeckia species while $86 \%$ of 0 . grande sampled in Macraes Flat, Otago contained seeds from Muehlenbeckia and Hymenanthera species, indicating that New Zealand lizards may play an important role in seed dispersal (Whitaker 1987). Additionally, Dactylocnemis pacificus have been observed feeding on the nectar from flowers of the New Zealand endemic pohutukawa tree (Metrosideros excelsa) in congregations as large as seven lizards per $\mathrm{m}^{2}$ (Whitaker 1987). The geckos were also observed covered in pollen over 50 metres from the nearest pohutukawa tree, providing an indication of the important role geckos might play in pollinating endemic New Zealand plant species (Whitaker 1987). This evidence suggests that New Zealand lizards might play a key role in the reproductive strategies of New Zealand endemic plant species. Lizard communities on islands free of rats can have extremely high species diversity 
(Towns 1990) and can attain densities of as many as 13 individuals $/ \mathrm{m}^{2}$ (Towns 1975). As a substantial component of island ecosystem biomass, lizards could have a significant impact on ecosystem functions.

In addition to providing ecosystem services, New Zealand lizards have been implicated in disease persistence and transmission in ecological systems. For example, Salmonella has been isolated from New Zealand endemic skinks and geckos on several offshore islands including Mana, Cuvier, Korapuki, Matiu and Stephens Islands (Middleton et al. 2010; Middleton et al; 2014). The potential for lizards to act as disease reservoirs on New Zealand's offshore islands may pose a threat to sympatric species.

A 2012 study revealed a potential connection between Salmonella infection in the endemic rail, the takahē (Porphyrio hochstetteri) from the private island, and contact with Salmonella infected lizards living sympatrically with these birds (Grange pers. comm. 2015). In addition to the private island, there are three mainland sites and four islands (Maud, Mana, Kapiti and Tiritirmatangi) throughout New Zealand that host takahē populations (Fig. 1). Considering the broad distribution of lizards throughout New Zealand (Tingley et al. 2013), it is extremely likely that takahē co-exist with lizard populations at all of these sites. Takahē are routinely moved throughout this translocation network (Grange et al. 2014) and any concomitant organisms are inevitably moved with them. If lizards at these sites represent a potential Salmonella reservoir, takahē who come into contact with them and become infected could pose a significant risk to the entire takahē population.

The private island is not managed by the Department of Conservation and has limited access. As a result, no scientific studies have been implemented to investigate lizard species, distribution and potential interactions with other species present there. Additionally, little is known about the lizard ecology on other islands in the takahē translocation network. This provides a clear example of an important gap in the knowledge concerning New Zealand endemic reptile species. Gaining fundamental ecological knowledge is critical to the conservation of any threatened species (Jenkins 1998), and information regarding health, 
distribution and density of lizards species on the private island and other sites within the takahē translocation network may be crucial to decisions regarding the urgency and course of conservation management for sympatric takahē.

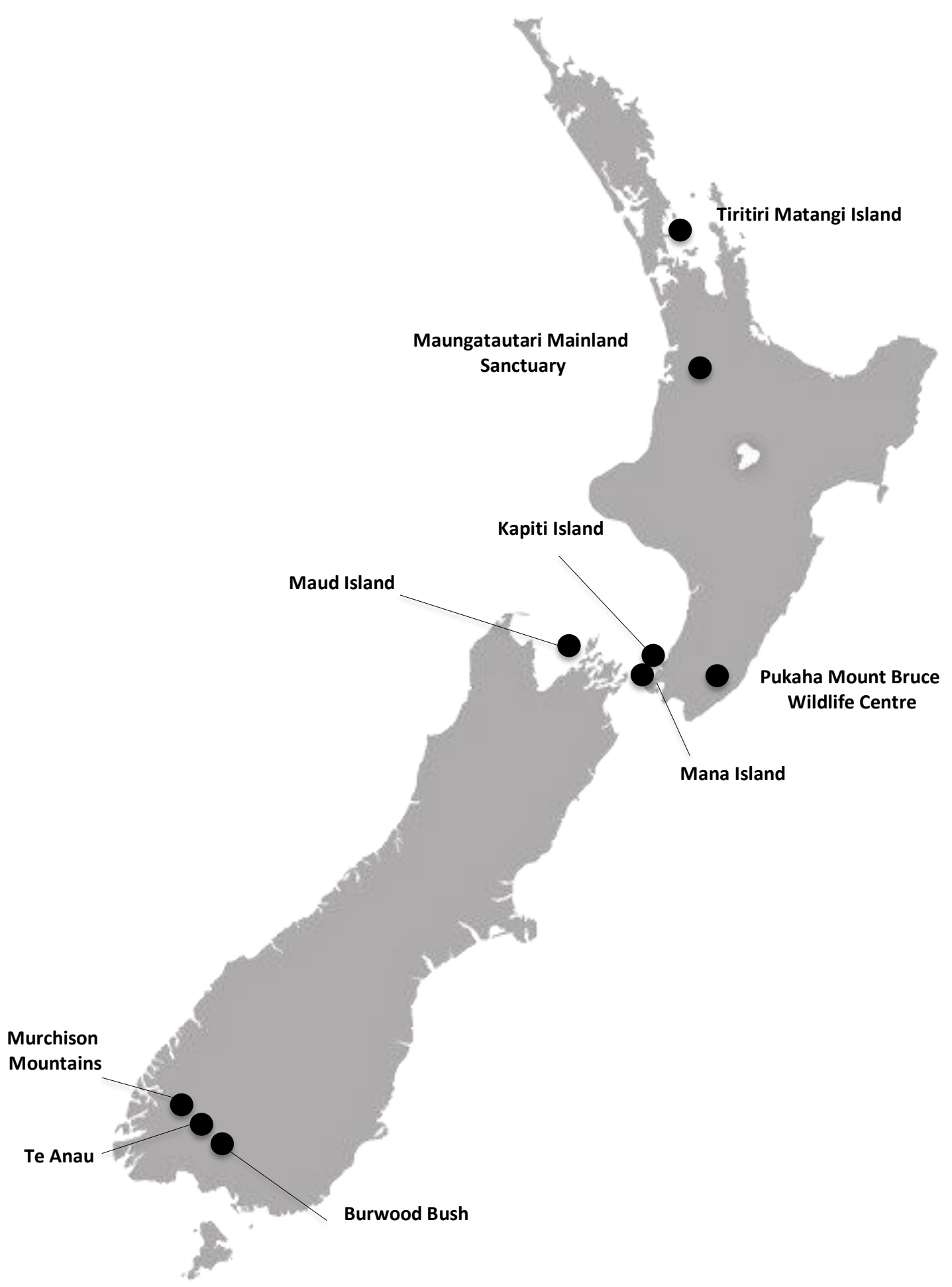


Figure 1: Map of takahē populations sites within New Zealand. Location of the private island not disclosed for security reasons.

The aim of this chapter is to provide basic information on the ecology of lizards within takahē territories on the private island and Maud Island by meeting the following objectives:

1. Investigate species composition of lizard communities within takahē territories on the private island and Maud Island.

2. Describe aspects of demography, morphology and distribution of lizards within takahē territories on the private island and Maud Island. 


\subsection{Methods}

Study Sites

Private Island

The private island is an approximately 100-hectare landmass in Foveaux Strait, New Zealand). It has a history of more than 100 years of intensive grazing by sheep and remained inhabited by humans up until 1989. It was returned to Te Rūnanga o Ngāi Tahu as Māori freehold land in 1998 (Ngai Tahu Claims Settlement Act 1998, Deed of Settlement Section 13) and is now free of both permanent human residents and livestock. Historic grazing and land clearing has resulted in vegetation cover dominated by native and exotic grass pastures and low growing shrubs including Hebe, bracken fern (Pteridium aquilinum var esculentum), flax (phormium tenax) and gorse (Ulex europlaeus). Restoration of island vegetation is ongoing, with gorse removal and native planting regularly carried out.

The Pacific rat Kiore (Rattus exulans) was eradicated from the island between 1997 and 1998 by Maori stakeholders and the Department of Conservation (McClelland 2002) and it has subsequently remained free of mammalian predators. The island now supports numerous endemic species including takahē (Porphyrio hochstetteri), tokoeka kiwi (Apteryx australis) and Hooker's sea lions (Phocarctos hookeri), in addition to several transient sea bird colonies including little blue penguins (Eudyptula minor), yellow eyed penguins (Megadyptes antipodes) and Southern black back gulls (Larus dominicanus). Introduced passerines such as dunnocks (Prunella modularis), starlings (Sturnus vulgaris) and sparrows (Passer domesticus) also inhabit the island. No surveys of the lizard population on the private island have been undertaken outside of this study and so little is known about the existing lizard assemblage. However, lizards distributed throughout the Stewart Island archipelago might be expected to occur on the private island. 
Species description of lizards in the Stewart Island Archipelago

Oligosoma notosaurus ("Southern Skink") is a diurnal, viviparous skink, endemic to New Zealand (Patterson \& Daugherty 1990). This species is distributed throughout the Stewart Island archipelago in Foveaux Strait, New Zealand including Stewart, Codfish and Betsy Islands and is found in sand dunes, grasslands, scrub and rocky areas at these sites (Patterson \& Daugherty 1990; IUCN Red List 2014). Its current New Zealand conservation status is "not threatened" (Hitchmough et al. 2013).

Oligosoma nigriplantare polychroma ("Common Skink") is a diurnal, viviparous skink, endemic to New Zealand. This species is distributed widely throughout both the North and South Island of New Zealand and several offshore islands and is commonly found in tussock and grasslands, scrub and rocky areas (Patterson \& Daugherty 1990). Its current conservation status is "at risk/declining" (Hitchmough et al. 2013).

Oligosoma stenotis ("Small-eared Skink") is a diurnal, viviparous skink, endemic to New Zealand. This species is only known to occur on Stewart Island and very little is known about its ecology (Towns \& Elliot 1996). Its current conservation status is "naturally uncommon" (Hitchmough et al. 2013).

Oligosoma inconspicuum ("cryptic skink") is a diurnal viviparous skink endemic to New Zealand. This species occurs throughout Otago and Southland and is commonly found in grass and tussockland, and rocky coastal sites (Whitaker et al. 2002). Its current conservation status is "at risk" (Hitchmough et al. 2013).

Oligosoma chloronoton ("green skink") is a diurnal viviparous skink endemic to New Zealand. This species occurs from the south of Canterbury to the Stewart Island archipelago and is found in coastal and inland grass and tussocklands. Its current conservation status is "at risk" (Hitchmough et al. 2013). 


\section{Maud Island}

Te Hoiere/Maud Island is a 309-hectare scientific reserve located in Pelorus Sound in Malborough Sounds New Zealand ( $41^{\circ} 01^{\prime} \mathrm{S}, 173^{\circ} 52^{\prime} \mathrm{E}$ ). The island has a long history of human modification including land clearing and intensive livestock grazing up until 1972. Only a small number of sheep are now retained in fenced areas on the island in order to provide grazing pasture for resident takahē. Re-vegetation efforts have resulted in a gradual reversion to young regenerating forest and shrubland dominated by whauwhaupaku (Pseudopanax arboreus), hebe, mahoe (Melicytus ramiflorus), tauhinu (Ozothamnus leptophylla), karamu (Coprosma robusta), bracken (Pteridium spp.), exotic pasture and approximately 25 hectares of native and pine remnant forest (Le Roux 2008).

Maud Island maintains a diverse, endemic avian fauna comprised of both land and sea birds. Takahē were first moved to the island in 1984 and a small population of up to 16 birds has been maintained there since (Department of Conservation, 2015). In addition to takahē, bell birds (Anthornis melanura), tui (Prosthemadera novaeseelandiae), the New Zealand falcon (Falco novaseelandiae), morepork (Ninox novaseelandiae), little blue penguins, black back (Larus Marinus) and red billed gulls (Larus novaehollandiae) and several species of cormorant maintain stable populations on the island. The island also supports its own species of frog, the Maud Island frog (Leiopelma pakeka) (Department of Conservation, 2015). The lizard community on Maud Island is comprised of the Stephen's island striped gecko (Toropuku stephensi), common gecko (Woodworthia maculatus), forest gecko (Mokopirirakau granulatus), brown skink (Oligosoma zealandicum), speckled skink (Oligosoma infrapunctatum) and common skink (Oligosoma nigriplantare polychroma) (Department of Conservation, 2015).

\section{Species descriptions of lizard species on Maud Island}

Toropuku stephensi ("Stephens Island gecko"; "striped gecko") is a nocturnal viviparous gecko endemic to New Zealand. It is found on Stephens Island, Maud 
Island and the Marlborough Sounds area and the Coromandel Peninsula in habitats such as lowland and coastal shrub and forest (Whitaker et al. 1999). Its current conservation status is "nationally vulnerable" (Hitchmough et al. 2013).

Mokopirirakau granulatus ("forest gecko") is a nocturnal viviparous gecko endemic to New Zealand. It is found in the northern half of the North Island and the Marlborough Sounds and Nelson in forest and shrubland. Its current conservation status is "at risk" (Hitchmough et al. 2013).

Oligosoma infrapunctatum ("speckled skink") is a diurnal viviparous skink endemic to New Zealand. It has a patchy distribution throughout the North Island and occurs in Nelson and the Marlborough Sounds and is found in grass and tussocklands, and open forest (Whitaker \& Lyall 2004). Its current conservation status is "at risk" (Hitchmough et al. 2013).

Oligosoma zelandicum (common name "Brown Skink") is a diurnal, viviparous skink, endemic to New Zealand. This species is distributed over the south of the North Island from Wellington to Taranaki, and the north of the South Island in Marlborough, Nelson and Westland and is commonly found in shady, moist habitats with abundant vegetation cover (Towns \& Elliot 1996). Its current conservation status is "at risk/declining" (Hitchmough et al. 2013).

Woodworthia maculatus (common name "Common Gecko") is a nocturnal, viviparous gecko, endemic to New Zealand. This species is distributed widely over North and South Islands and is commonly found in low forest shrub and rocky coastal areas (Towns \& Elliot 1996). Its current conservation status is "not threatened" (Hitchmough et al. 2013).

Oligosoma nigriplantare polychroma: See above for species description.

While Maud Island was previously classified as a predator free reserve, a mouse infestation was detected in late 2013 and efforts to control the outbreak are ongoing (Phil Marsh, pers. comm. 2014). Additionally, there are occasional 
incursions of the omnivorous weka (Gallirallus australis) and carnivorous stoat (Mustela erminea) from the mainland, and trapping is routinely carried out to control these incursions.

\section{Lizard survey}

I carried out mark-recapture surveys of the lizard populations within accessible takahē territories on the private island and Maud Island. Each survey was carried out over five consecutive days during January 2014 on the private island and February 2014 on Maud Island. Accurate delineation of takahē territories is difficult as little is known about how far the takahē range on both the private island and Maud Island. However, staff at each of the islands determined the approximate extent of each territory using sightings of individual birds as a guide. The private island takahē population consists of approximately 20 birds at any one time (Phil Marsh pers. comm. 2014) and eight accessible takahe territories suitable for lizard pitfall placement were identified (Fig. 1). Six takahē territories suitable for lizard pitfall grid placement were identified on Maud Island (Fig. 3), as there are a comparatively small number of takahē with numbers ranging from eight to 16 birds at any one time (Phil Marsh pers. comm. 2014).

I used a random stratified design for the placement of pitfall traps within each territory. A random compass direction and distance of ten metres from each territory's water source were assigned for the starting points of transects. Three transect lines consisting of four pitfall traps each were allocated to each takahē territory (12 traps total) and traps were placed four metres apart to account for the naturally small home range size of New Zealand lizards (Towns \& Elliot 1996; Coddington \& Cree 1997). In cases where selected pit fall placement sites were inaccessible, traps were placed in the nearest suitable area. Additionally, because surveys were undertaken during the takahē breeding season, areas of undergrowth with potential takahē tracks were avoided to minimise disturbance to the birds and their chicks and reduce the likelihood of birds tampering with the traps. In the case of the private island, three traps from transect $\mathrm{E}$ were 
flooded due to the high water table in this area. As a result, these traps and area directly surrounding them were excluded from all analyses.

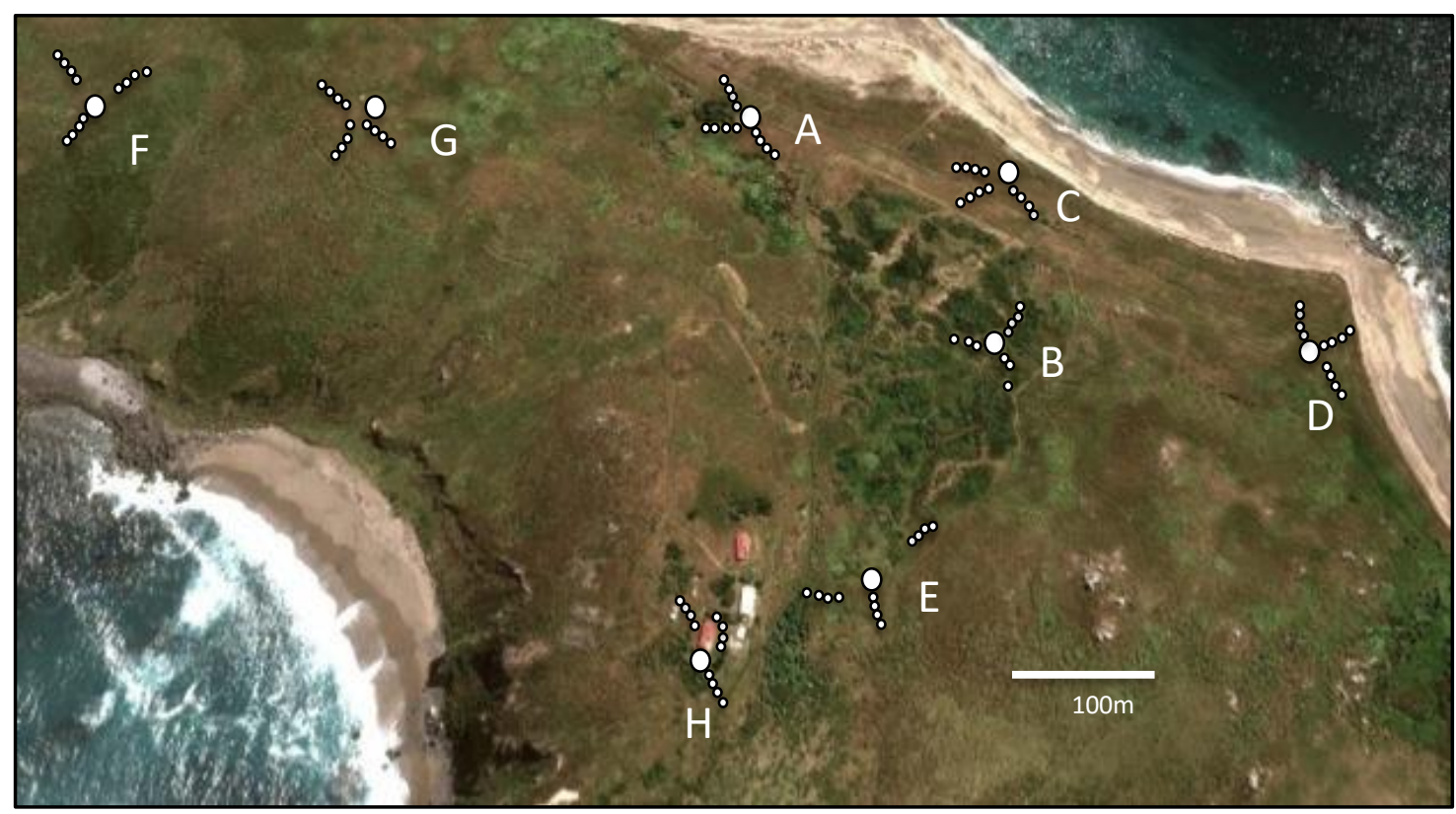

Figure 2: Map of pitfall transects on the private island. Large circles indicate takahē water sources within pitfall transects and small circles indicate pitfall trap placement. Large-scale map of the private island not provided to protect its location. Image from Google Earth ,2014.

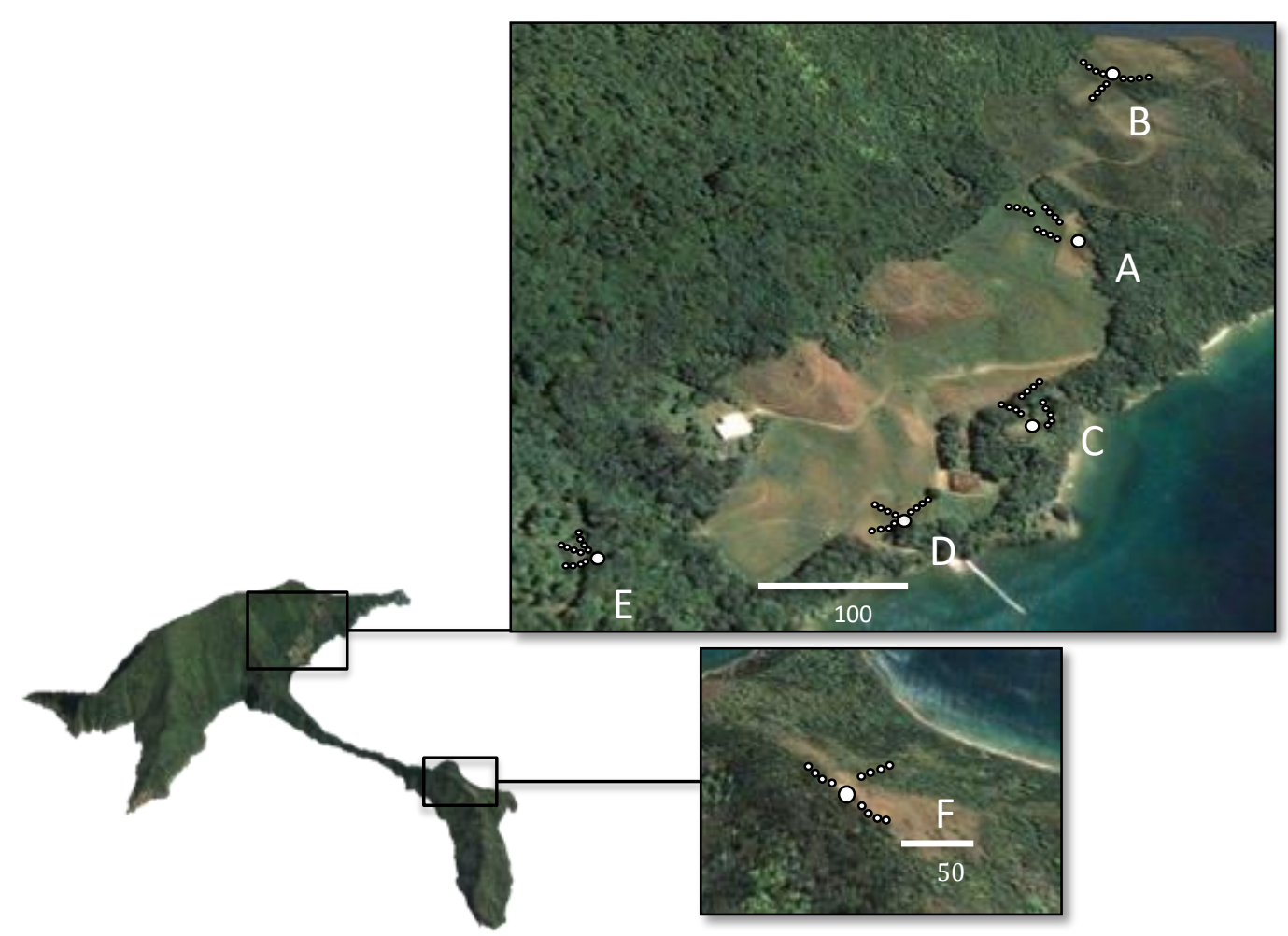

Figure 3: Map of Maud Island with pitfall grid areas enlarged. Large circles indicate takahē water sources within pitfall grids and small circles indicate pitfall trap placement. Images from Google Earth, 2015. 
Pit fall traps used in this study conform to the guidelines outlined in the Department of Conservation document Herpetofauna: pitfall-trapping v 1.0. I used four litre, straight sided, white plastic buckets with drainage holes drilled in the bases (Fig. 4). Traps were dug in flush with the ground and edges packed with substrate to allow easy access for lizards. Bucket lids were secured in place over each trap using steel garden pegs to prevent flooding and reduce the risk of trapped lizards becoming desiccated at higher temperatures. Moistened sponges were placed in the bottom of each trap and checked daily to further reduce the risk of heat stress to lizards. A gap of two centimetres was left between the bucket and lid to allow access for lizards while excluding potential lizard predators such as takahē, kiwi and weka.

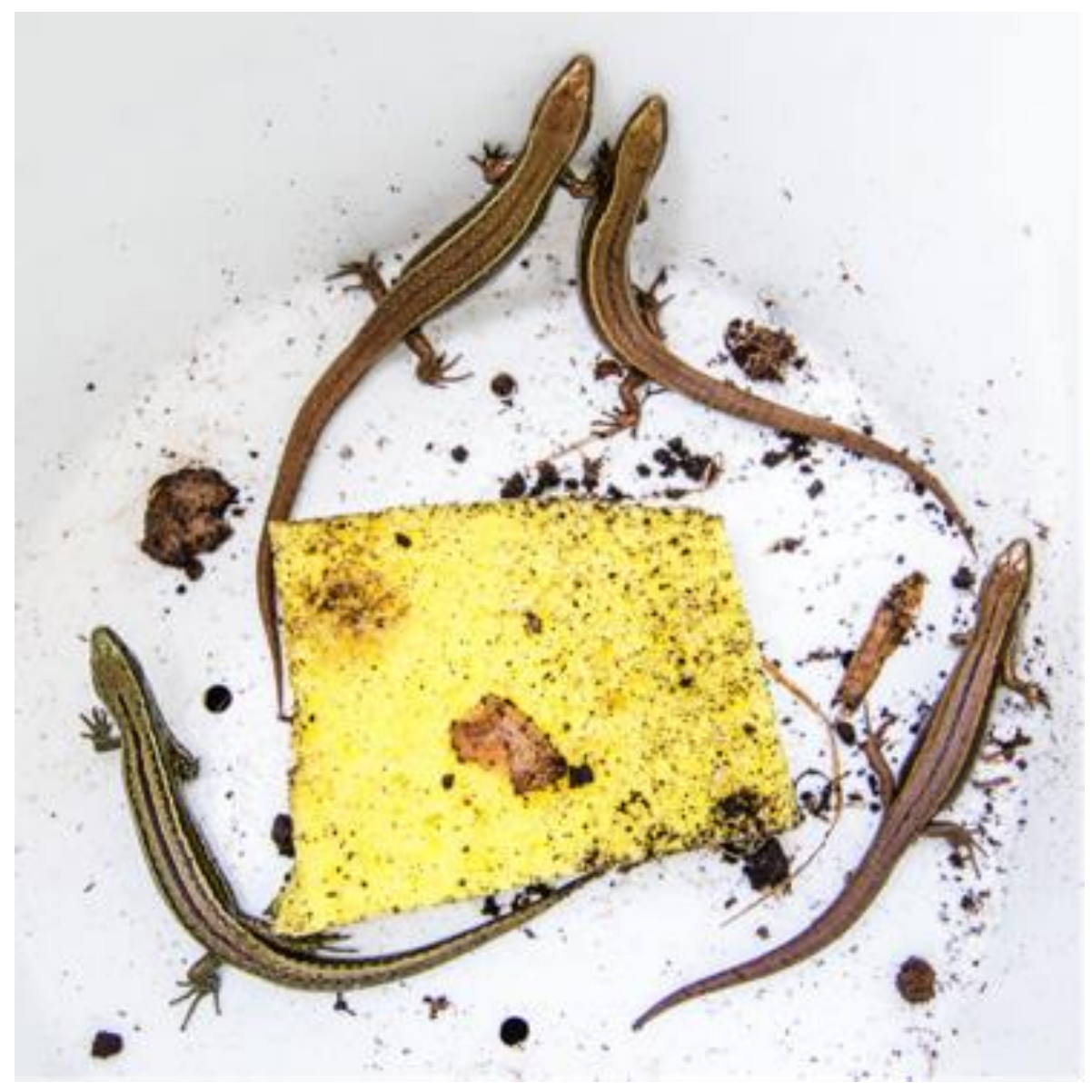

Figure 4: Lizard pitfall trap on the private island. Photo courtesy of Thomas Burns. 
I recorded features of trap locations including GPS coordinates, vegetation type and height, and each trap was issued individual identification including territory and trap number. Pitfall traps were baited with pear and checked in the same sequence each day to ensure that a full 24-hour period passed between checks.

Lizards caught were held in gauze bags prior to processing to minimize handling and stress to the animals. Trap identity, species, sex, age group (juvenile, subadult, adult), snout-vent length (SVL), vent-tail length (VTL) and weight were recorded for each individual and the reproductive status of female lizards was determined via abdominal palpation. A unique identifying number was applied to the ventral surface of each individual using a non-toxic, xylene free $\operatorname{artline}{ }^{\circledR}$ pen and unknown species were photographed for later identification. Lizards were then released adjacent to their capture trap location.

\section{Statistical Analyses}

\section{Population number estimates}

I used a weighted mean model to estimate population numbers of lizards on both the private and Maud Island (Begon 1979). This model is a modification of the simple Petersen estimate that allows for low numbers of captures and the use of data collected over several days.

\section{Weighted mean model}

$$
\widehat{N}=\frac{\sum m_{i} n_{i}}{\left(\sum M_{i}\right)+1}
$$

Where $\widehat{N}=$ estimation of the population mean, $m_{i}=$ the number of individuals caught on day $i$, $M_{i}=$ the number of marks at risk on day $i$ and $n_{i}=$ the number of individuals caught on day $i$. 


$$
S E_{\widehat{N}}=\widehat{N} \sqrt{\frac{1}{\sum m_{i}+1}+\frac{2}{\left(\sum m_{i}+1\right)^{2}}+\frac{6}{\left(\sum m_{i}+1\right)^{3}}}
$$

The validity of the weighted mean model relies on the same set of assumptions as the Petersen estimate:

1. The population is closed and population size is constant over the sampling period. This means there are no births or deaths and no immigration or emigration in the population over the course of the study.

2. All identifying marks attributed to animals are permanent for the course of the study.

3. Identifying marks are not misread on subsequent captures.

4. Capture and marking of animals has no effect on catchability of individual animals or on the individual animal's chances of dying or emigrating.

5. Each individual animal in the population has an equal probability of being caught.

The majority of the above assumptions were met on both the private island and Maud Island. Both sampling periods were carried out over the relatively short period of five days, limiting the number of gains and losses to the population. Both islands are also geographically isolated, restricting immigration and emigration but some degree of lizard movement between traps is inevitable. However, the pitfall traps were placed four metres apart reflecting the home range size of many New Zealand lizard species (Towns \& Elliot 1996), thus limiting movement of lizards outside of pitfall transects. Individual marks were deemed permanent for the course of the survey as indicated by lizards originally marked on the first day of the sampling period on the private island retaining their marks until recapture on the last day of the sampling period. All field team members were involved in the marking of captured lizards and interpretation of recaptured lizard's marks, reducing the probability of misidentification of marks. For the purpose of these analyses, I assumed that capture and marking of lizards did not affect their subsequent catchability as handling times were minimised 
and the marking technique was non-invasive. However, there is the possibility that some individuals became "trap shy" after initial handling, making future recaptures less likely. Additionally, the assumption of equal catchabillity of individuals in a population is difficult to assess and may not have been met in this case. Patterns of lizard catchabillity may have been discernible if sufficient numbers were caught to analyse data in a sophisticated mark recapture program such as MARK. MARK has the capacity to include factors such as variable individual capture probabilities in the estimation of population sizes while simple models such as the weighted mean are not able to account for such variation.

Minimum numbers alive

$$
M N A=\text { Captures }_{\text {total }}-\text { Recaptures }_{\text {total }}
$$

MNA is a model commonly used to provide a rough indication of animal abundance and relies on the same assumptions as the weighted mean model (Hare 2012).

\section{Sex ratios}

I used chi square goodness of fit tests to examine whether sex ratios of lizard species captured differed from 1:1.

\section{Density estimates}

I estimated lizard density for the private island and Maud Island using both the population estimates obtained from the weighted mean model and those from MNA. Areas for density estimates were extrapolated out from the total area covered by pitfall transects, including an area of four metres radiating out from transect lines to account for spill over between lizard territories. Three pitfall traps in transect B were flooded at the beginning of the survey and so the area surrounding these traps was excluded from density estimates. I excluded the 25 hectares of forest from analysis of Maud Island densities due to the dissimilarity of this habitat to the habitats I was able to sample on the island. In contrast, the private island is dominated by pasture and low shrub, and as I was able to 
sample in both these habitats, I included the entire island area in density analysis.

\section{Effects of temperature and humidity on lizard capture rates}

I used a linear regression to assess the effect that temperature had on lizard capture rates on the private island. Relative humidity data were not available for the private island or Maud Island during the relevant capture period and so the effects of temperature only on capture rates was assessed. Temperature data for the private island were obtained from the Stewart Island weather station and Maud Island data were obtained from the closest available weather station in Crail Bay, Pelorus Sound. Temperature data were obtained from the NIWA National Climate Database.

\section{Effects of habitat on lizard capture rates}

I conducted $F$ tests to compare capture rates of lizards over habitat types. Different habitats were defined by the dominant height and structure of vegetation surrounding each pit fall trap and standardised to fit into three groups for ease of analysis. Pasture and native grasses over 10 centimetres in height were grouped together as "grass", low-lying bush less than 1.5 metres in height including bracken, Coprosma spp., gorse and flax were grouped together as "shrub". The remaining habitat grouping was defined as leaf litter and only occurred on Maud Island. I used chi square goodness of fit tests to assess whether habitat type had any effect on capture rate of males, females or juveniles. 


\subsection{Results}

\section{Capture Summaries and lizard morphological measurements}

Private island: Three species of skink were captured on the private island. These were the Southern skink (Oligosoma notosaurus, Fig. 4) 91.5\% of total captures, common skink (Oligosoma nigriplantare polychroma)) 7.5\% of total captures, and small-eared skink (Oligosoma stenotis, Fig. 5, identified by James Reardon DOC) $1.1 \%$ of total captures.

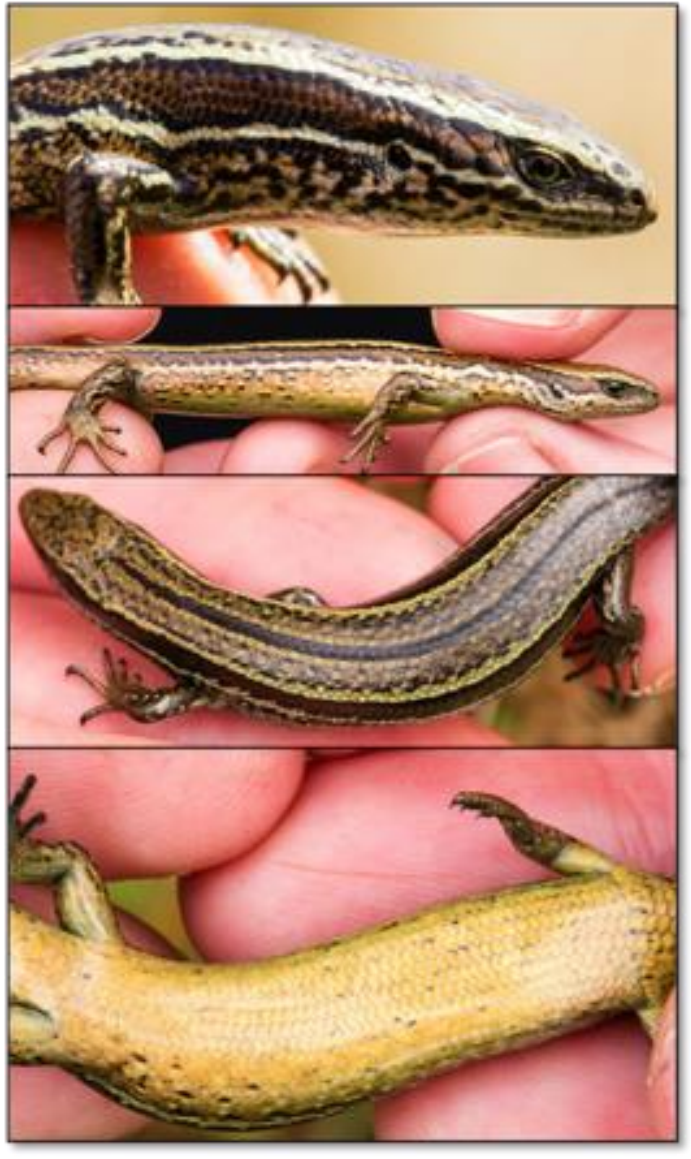

Figure 4: Oligosoma notosaurus captured on private island. From the top, lateral, dorsal and ventral views. Photos courtesy of Thomas Burns.

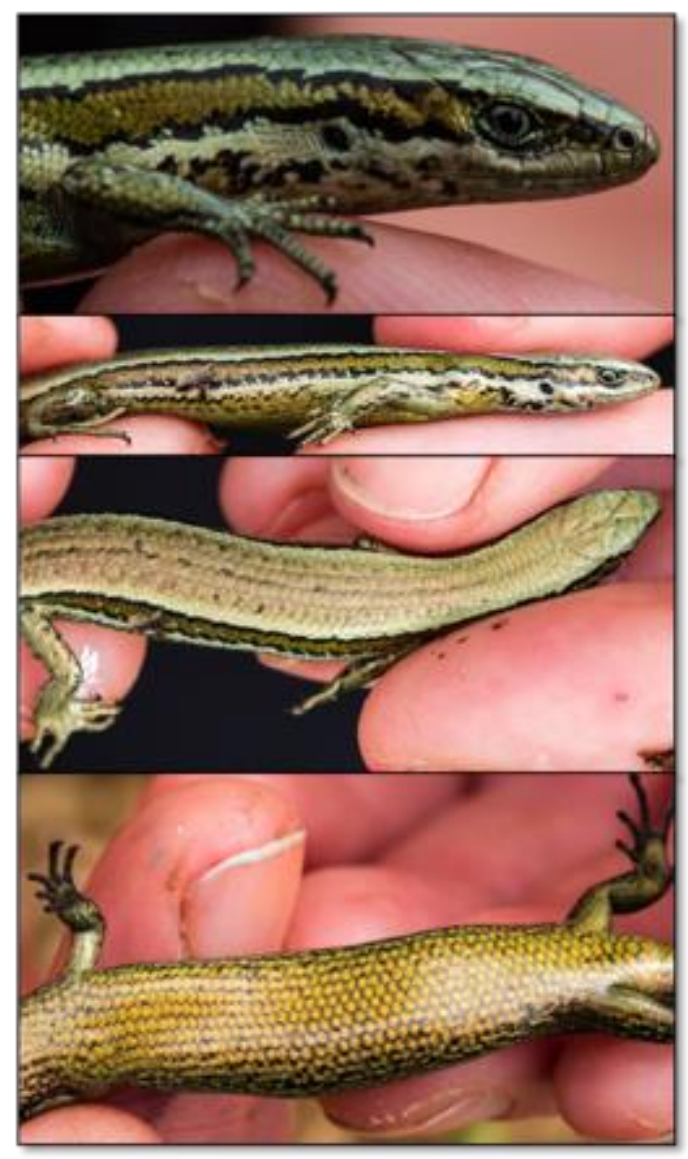

Figure 5: Oligosoma stenotis captured on private island. From the top, lateral, dorsal and ventral views. Photos courtesy of Thomas Burns.

A total of 176 skinks were captured with four recaptures. Of the adult and subadult 0 . notosaurus captures, males accounted for 33\% and females $67 \%$, while juveniles accounted for $14 \%$ of total 0 . notosaurus captures (Table 1 ). 


\begin{tabular}{ccccc}
\hline Species & Male & Female & $\begin{array}{c}\text { Juvenile (sex } \\
\text { unknown) }\end{array}$ & Total captured \\
\hline $\begin{array}{c}\text { Oligosoma notosaurus } \\
\text { Oligosoma stenotis }\end{array}$ & 45 & 91 & 25 & 161 \\
$\begin{array}{c}\text { Oligosoma nigriplantare } \\
\text { polychroma }\end{array}$ & 1 & 1 & 0 & 2 \\
Total captures & 50 & 98 & 28 & 13 \\
\hline
\end{tabular}

Table 1: Summary of lizard captures from the private island.

A Chi square goodness of fit test found the sex ratio of adult and sub-adult $O$. notosaurus (49:100, male to female) was significantly different from the expected 1:1 ratio $\left(X^{2}(1, \mathrm{~N}=136)=15.559, p<0.0001\right)$. Of the adult and sub-adult O. nigriplantare polychroma captures, $40 \%$ were male and $60 \%$ female, while juveniles made up 23\% of captures. The sex ratio in adult and sub-adult $O$. nigriplantare polychroma was not significantly different from the expected 1:1 ratio $\left(X^{2}(1, \mathrm{~N}=10)=0.400, p=0.5271\right)$. Two adult 0 . stenotis were captured, one male and one female. A summary of morphology and sex proportions of lizards captured on the private island is reported in Table 2.

\begin{tabular}{|c|c|c|c|c|c|c|}
\hline Species & Sex & $\begin{array}{c}\text { Proportion } \\
\text { pregnant }\end{array}$ & $\begin{array}{c}\text { Proportion of } \\
\text { sex }\end{array}$ & $\begin{array}{c}\text { Average SVL } \\
(\mathrm{mm})(\mathrm{SD})\end{array}$ & $\begin{array}{l}\text { Weight (g) } \\
\text { (SD) }\end{array}$ & $\begin{array}{c}\text { Total proportion } \\
\text { of captures }\end{array}$ \\
\hline \multirow{2}{*}{$\begin{array}{c}\text { Oligosoma } \\
\text { nigriplantare } \\
\text { polychroma }\end{array}$} & $M$ & & 0.4 & $55.5(3.32)$ & $2.98(0.84)$ & \\
\hline & $\mathrm{F}$ & 0.67 & 0.6 & $60.2(7.05)$ & $3.58(1.43)$ & \\
\hline \multirow{2}{*}{$\begin{array}{l}\text { Oligosoma } \\
\text { notosaurus }\end{array}$} & $M$ & & 0.33 & $54.62(4.76)$ & $2.82(0.74)$ & 0.92 \\
\hline & $\mathrm{F}$ & 0.4 & 0.67 & $57.83(5.08)$ & 3.56 (1.09) & \\
\hline \multirow{2}{*}{$\begin{array}{l}\text { Oligosoma } \\
\text { stenotis }\end{array}$} & M & & 0.5 & 64 & 3.3 & 0.01 \\
\hline & $\mathrm{F}$ & 0 & 0.5 & 52 & 2.2 & \\
\hline
\end{tabular}

Table 2: Summary of morphology, reproductive status and proportions of lizards captured on the private island.

Maud Island: Three species of lizard were captured on Maud Island, the brown skink (Oligosoma zelandicum) (Fig. 6) 47.5\% of total captures, the common skink 
(Oligosoma nigriplantare polychroma) (Fig. 6) 5\%, and the common gecko (Woodworthia maculatus) (Fig. 7) 47.5\% of total captures.

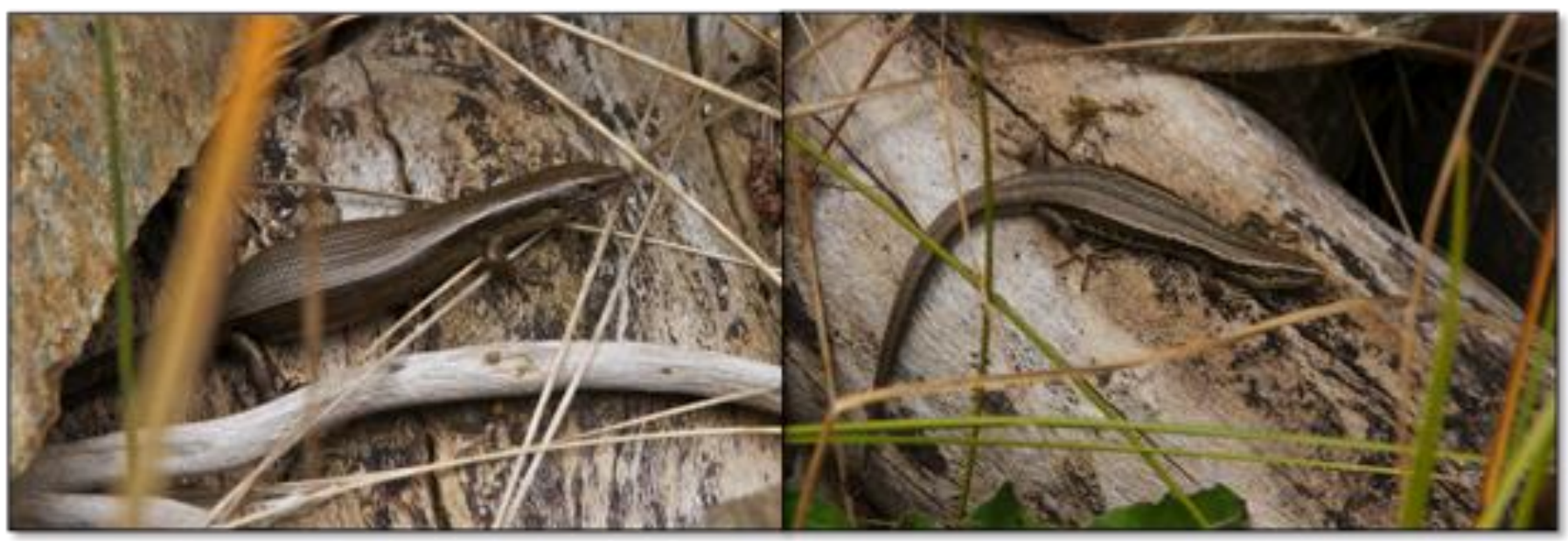

Figure 6: Left: Oligosoma zelandicum, right: Oligosoma nigriplantare polychroma. Photos courtesy of Steve Attwood, Auldwood Photography.

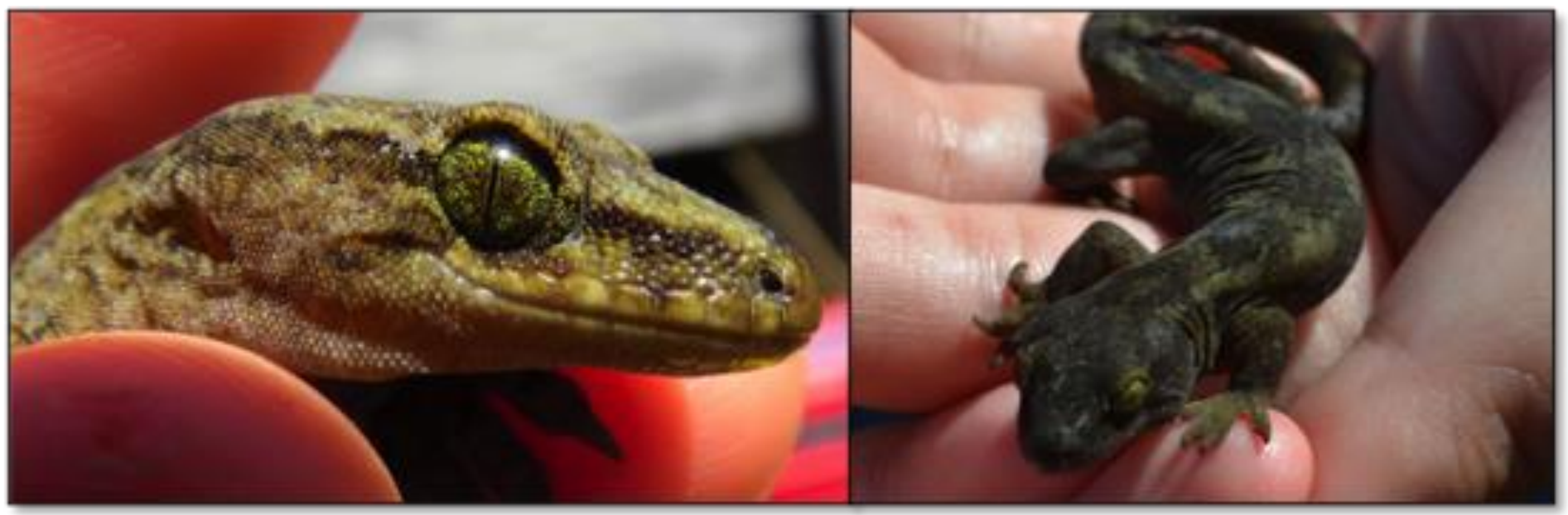

Figure 7: Woodworthia maculatus. Left photo courtesy of Thomas Burns, right photo S. Rose.

A total of 34 lizards were captured in pitfall traps. Ten lizards were captured by hand inside takahē territories but outside of pitfall transects and were therefore excluded from density estimates. There were no recaptures. A summary of hand captured lizards in reported in Table 3 and a summary of morphology and sex proportions of lizards captured is reported in Table 4.

\begin{tabular}{|c|c|c|c|c|}
\hline Species & Male & Female & $\begin{array}{c}\text { Juvenile (sex } \\
\text { unknown) }\end{array}$ & Total captured \\
\hline
\end{tabular}




\begin{tabular}{ccccc}
\hline $\begin{array}{c}\text { Oligosoma zelandicum } \\
\text { Woodworthia maculatus }\end{array}$ & 3 & 9 & 2 & 14 \\
$\quad 10$ & 10 & 0 & 20 \\
$\quad$ Total captures & 13 & 19 & 2 & 34 \\
$\quad \begin{array}{c}\text { Total proportion of } \\
\quad \text { captures }\end{array}$ & 0.38 & 0.56 & 0.06 & \\
\hline
\end{tabular}

Table 3: Summary of lizards captured in pitfall traps on Maud Island.

\begin{tabular}{ccccc}
\hline Species & Male & Female & $\begin{array}{c}\text { Juvenile (sex } \\
\text { unknown) }\end{array}$ & Total captured \\
\hline $\begin{array}{c}\text { Oligosoma zelandicum } \\
\text { Woodworthia maculatus }\end{array}$ & 0 & 7 & 0 & 7 \\
$\begin{array}{c}\text { Oligosoma nigriplantare } \\
\text { polychroma }\end{array}$ & 0 & 1 & 0 & 1 \\
\end{tabular}

Table 4: Summary of lizards caught by hand on Maud Island.

Of the adult 0 . zealandicum, males accounted for $13 \%$ of adult captures and females $87 \%$, while juveniles accounted for $9.5 \%$ of total 0 . zelandicum captures. The sex ratio of adult and sub-adult 0 . zelandicum (18:100, male to female) was significantly different from the expected $1: 1$ ratio $\left(X^{2} \quad(1, N=19)=8.895\right.$, $p=0.0029$ ). Of the adult and sub-adult $H$. maculatus captures, $48 \%$ were male and $52 \%$ female. The sex ratio in adult and sub-adult $H$. maculatus was not significantly different from the expected $1: 1$ ratio $\left(X^{2}(1, N=21)=0.048\right.$, $p=0.8273$ ). Two sub-adult $O$. nigriplantare polychroma were captured, both female. A summary of morphology and sex proportions of lizards captured in pitfall traps on Maud Island is reported in Table 5.

\begin{tabular}{ccccccc}
\hline Species & Sex & $\begin{array}{c}\text { Proportion } \\
\text { pregnant }\end{array}$ & $\begin{array}{c}\text { Proportion of } \\
\text { sex }\end{array}$ & $\begin{array}{c}\text { Average SVL } \\
\text { (mm) (SD) }\end{array}$ & $\begin{array}{c}\text { Weight (g) } \\
\text { (SD) }\end{array}$ & $\begin{array}{c}\text { Total proportion of } \\
\text { captures }\end{array}$ \\
\hline & & & & & & \\
Oligosoma & $\mathrm{M}$ & & 0.13 & $55.5(6.36)$ & $3.85(0.07)$ & 0.41 \\
zelandicum & & & & & & \\
& $\mathrm{F}$ & 0.63 & 0.87 & $62.38(5.17)$ & $6.18(1.63)$ & $9.28(2.19)$ \\
& $\mathrm{M}$ & & 0.5 & $68.6(3.75)$ & 9.59
\end{tabular}



$\mathrm{F}$
0.8
0.5
67.9 (5.19)
$8.67(1.33)$

Table 5: Summary of morphology, reproductive status and proportions of lizards captured on Maud Island.

Population and density estimates

\begin{tabular}{cccccc}
\hline Study site & $\begin{array}{c}\text { Total area of } \\
\text { all pitfall } \\
\text { transects }\left(\mathbf{m}^{2}\right)\end{array}$ & $\begin{array}{c}\text { Weighted mean } \\
\text { population estimate } \\
\text { for all pitfall } \\
\text { transects }\end{array}$ & $\begin{array}{c}\text { MNA over all } \\
\text { pitfall } \\
\text { transects }\end{array}$ & $\begin{array}{c}\text { Weighted mean } \\
\text { density estimate } \\
\text { per hectare }\end{array}$ & $\begin{array}{c}\text { MNA density } \\
\text { estimate per } \\
\text { hectare }\end{array}$ \\
\hline Private island & 3776 & 2273 (SE 6819) & 176 & 6020 & 466 (SD 230) \\
Maud Island & 2880 & 440 (SE 7163) & 34 & 1528 & 118 (SD 164) \\
\hline
\end{tabular}

Table 6: lizard population number and density estimates from weighted mean model and MNA for the private island and Maud Island.

\begin{tabular}{cccc}
\hline Site & Pitfall transect area $\left(\mathbf{m}^{2}\right)$ & Lizards captured & Density (lizards/ha) \\
\hline A & 480 & 17 & 354 \\
B & 416 & 18 & 433 \\
C & 480 & 17 & 354 \\
D & 480 & 38 & 792 \\
E & 480 & 41 & 854 \\
F & 480 & 20 & 417 \\
G & 480 & 12 & 250 \\
H & 480 & 13 & 271 \\
Mean & & $\mathbf{2 2}$ & $\mathbf{4 6 6}$ \\
\hline
\end{tabular}

Table 7: Private island lizard densities per pitfall site based on MNA. Mean density per pitfall grid 446 (S.E. 3). Three pitfall traps were removed from site B due to flooding and the area of this transect reflects this.

\begin{tabular}{cccc}
\hline Site & Pitfall transect area $\left(\mathbf{m}^{\mathbf{2}}\right)$ & Lizards captured & Density (lizards/ha) \\
\hline A & 480 & 0 & 0 \\
B & 480 & 0 & 0 \\
C & 480 & 6 & 125 \\
D & 480 & 3 & 63 \\
E & 480 & 4 & 83
\end{tabular}


Table 8: Maud Island lizard densities per pitfall site based on MNA. Mean density per pitfall grid 118 (S.E. 67).

\section{Effect of temperature on capture rates}

There was a strong positive correlation between maximum daily air temperature on the day of sampling and lizard capture rates on the private island $\left(\mathrm{R}^{2}=0.9, F\right.$ $(1,3)=27.15, p=0.014)$, (Fig. 8). No significant association was found between maximum daily air temperature on the day of sampling and lizard capture rates on Maud Island $\left(\mathrm{R}^{2}=0.570, F(1,3)=3.98, p=0.14\right)$, (Fig. 9).

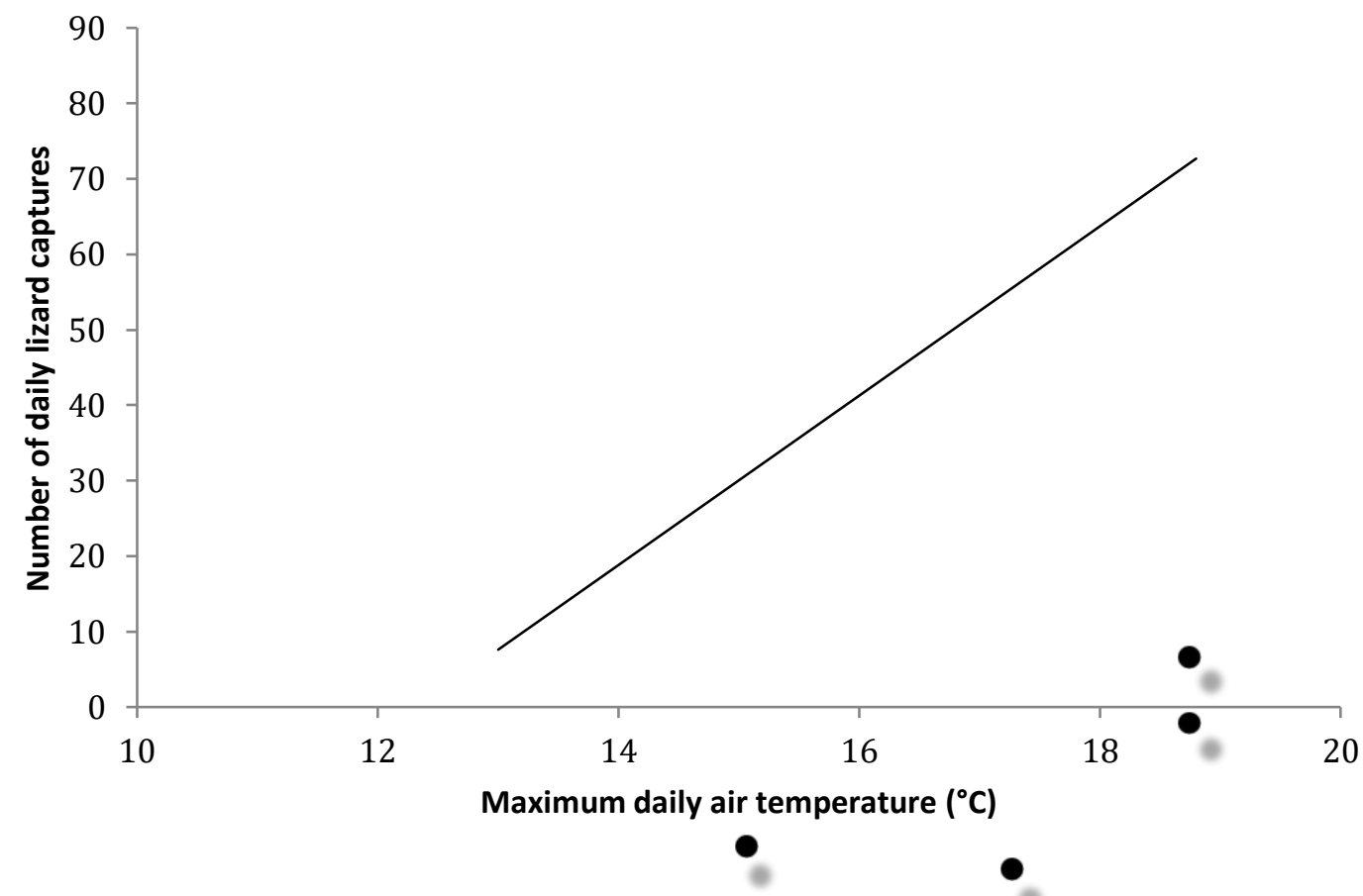

Figure 8: Linear regression showing the positive relationship between maximum daily air temperature and total number of daily lizard captures on the private island $\left(R^{2} 0.9\right)$. Maximum air temperatures obtained from the Stewart Island weather station, NIWA National Climate Database. 


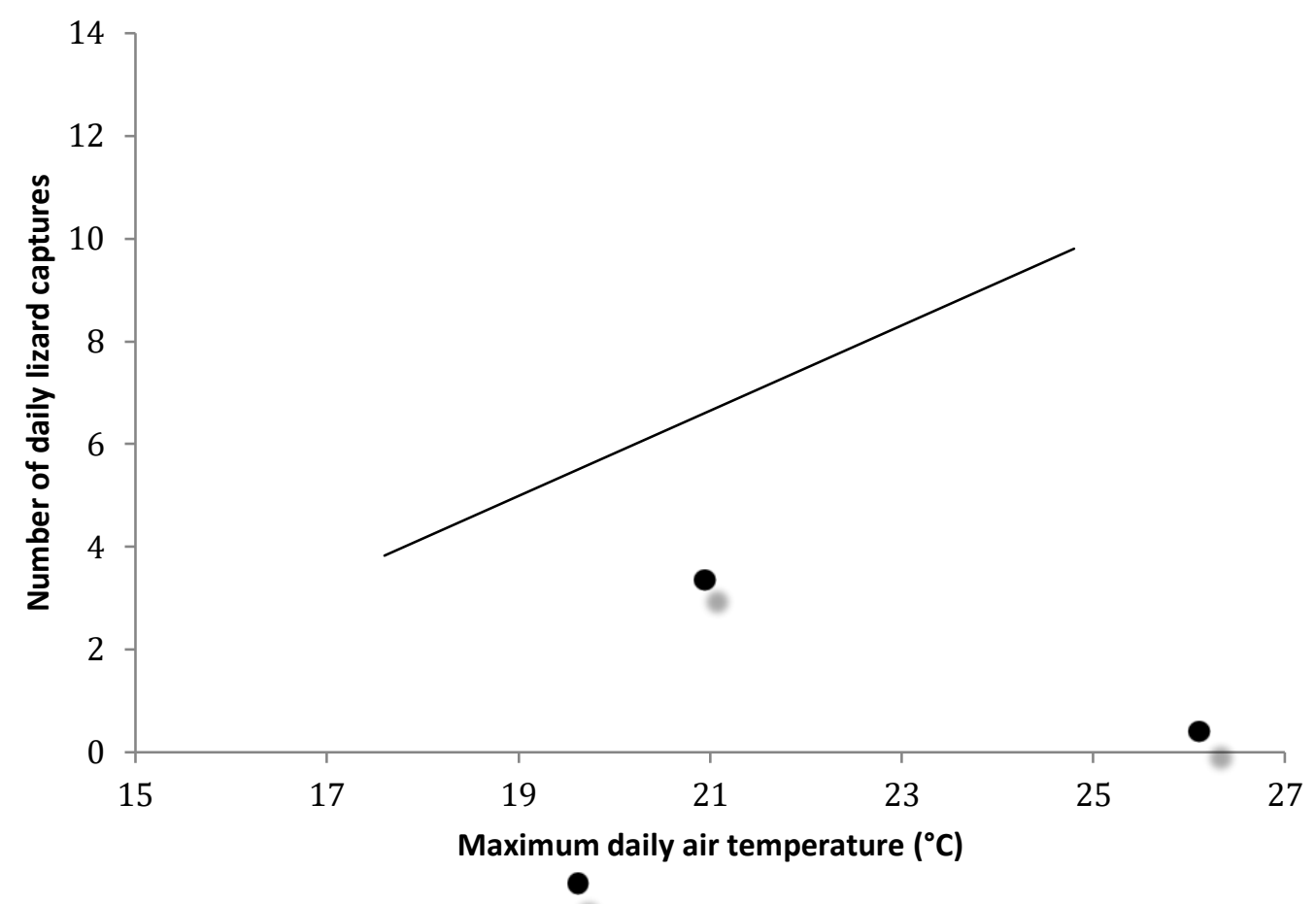

Figure 9: Linear regression showing a weakly positive relationship between maximum daily air temperature and total number of daily lizard captures on the Maud Island ( $\left.R^{2} 0.570\right)$. Maximum air temperatures obtained from the Crail Bay weather station, NIWA National Climate Database.

Effect of vegetation type on lizard capture rates

Private island: There was no significant effect of vegetation type on total capture rates for the private island $F(1,91)=1.596, p=0.210$ (Fig. 10). Chi square goodness of fit tests showed no significant difference in female lizard catches according to vegetation type $\left(X^{2}(1, N=98)=0.163, p=0.6862\right)$, male lizard captures according to vegetation type $\left(X^{2}(1, N=50)=0.320, p=0.5716\right)$, or juvenile lizard captures according to vegetation type $\left(X^{2}(1, \mathrm{~N}=28)=0.143\right.$, $p=0.7055)$ (Fig. 11). 


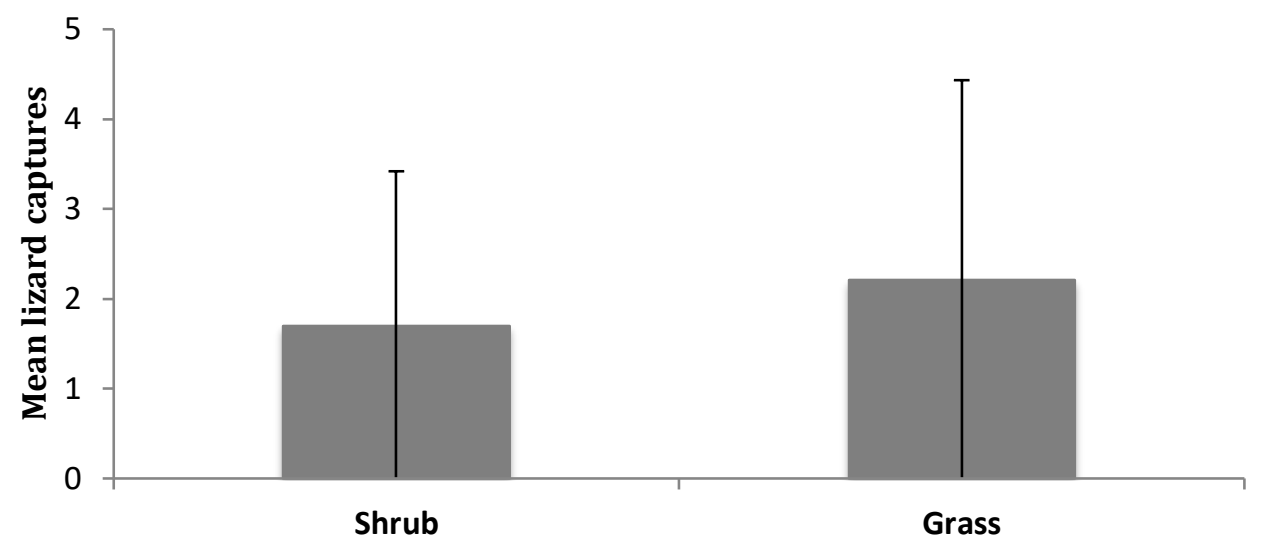

Figure 10: Mean lizard captures by vegetation type surrounding pitfall traps on the private island. Shrub N=85, Grass N=91 (+/- 1 SD). No significant difference in total lizard capture rates between habitats was found.

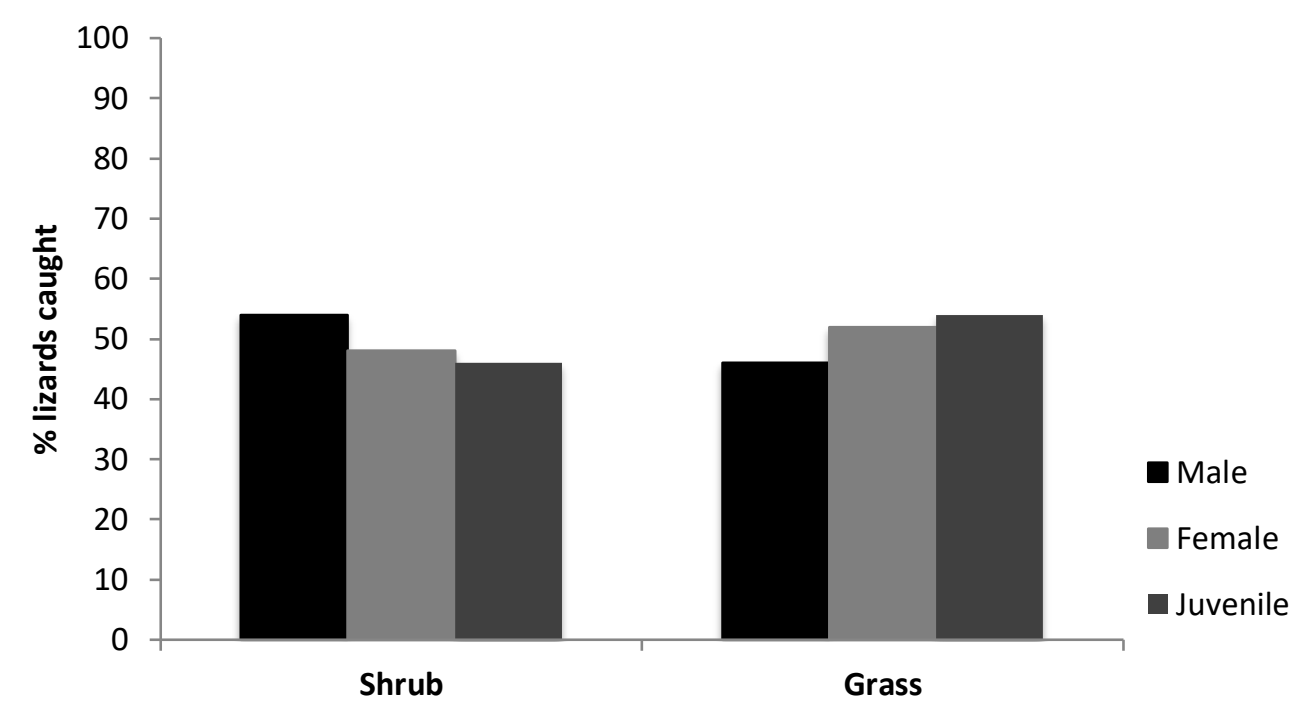

Figure 11: Percentage of male, female and juvenile captures in pitfall traps surrounded by each vegetation type on the private Island. Male $N=50$, Female $N=98$, Juvenile $N=28$. There was no significant effect of vegetation type surrounding pitfall trap on age group trapped.

Maud Island: There was no significant effect of vegetation type on total capture rates for Maud Island $F(2,69)=0.704, p=0.498$ (Fig. 12). Chi square goodness of fit tests showed no significant difference in female lizard catches according to vegetation type $\left(X^{2}(1, N=17)=2.882, p=0.0896\right)$ or male lizard captures according to vegetation type $\left(X^{2}(1, \mathrm{~N}=12)=3.000, p=0.0833\right)$ (Fig. 13). Juveniles and leaf litter were excluded from Chi square analysis due to low values. 


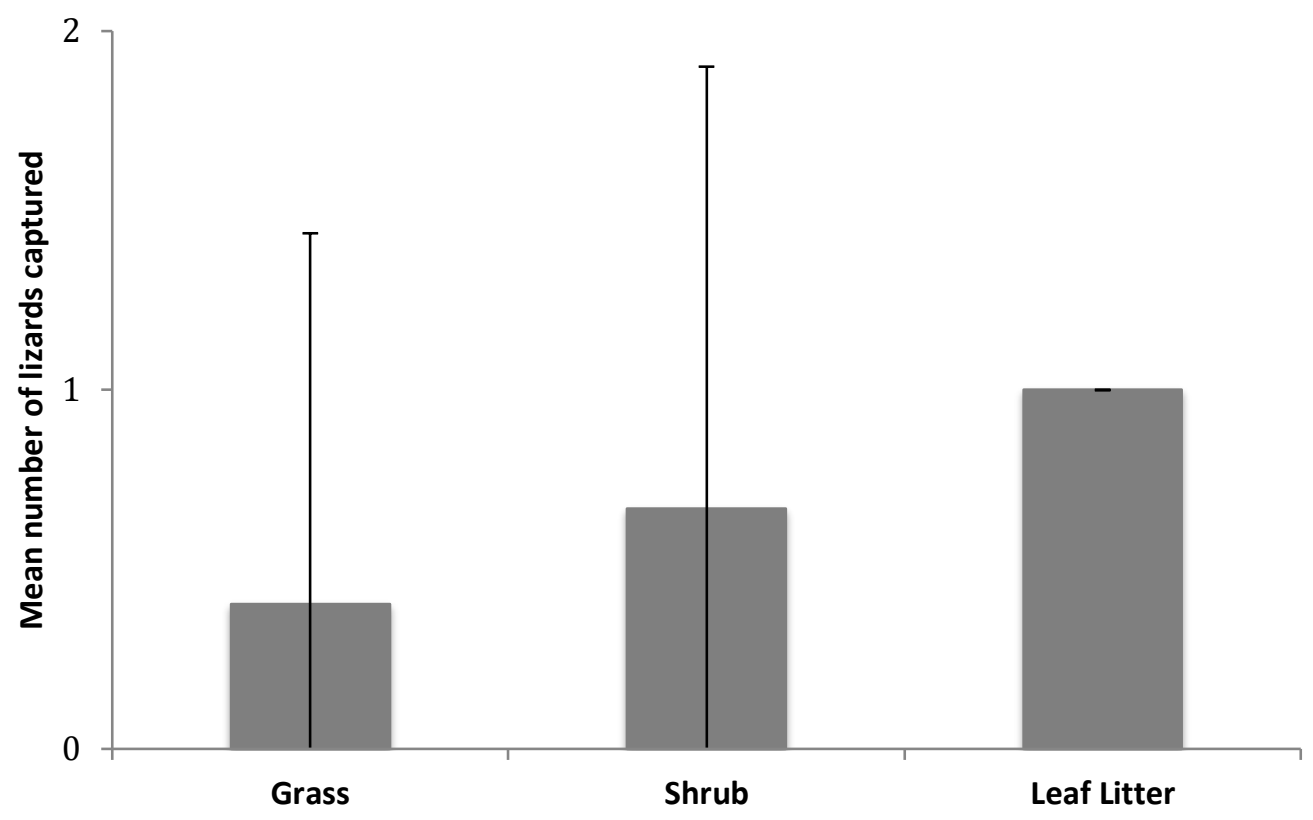

Figure 12: Mean lizard captures by vegetation type surrounding pitfall traps on Maud Island. Leaf litter $\mathrm{N}=3$, Shrub $\mathrm{N}=8$, Grass $\mathrm{N}=3$ (+/- $1 \mathrm{SD})$. No significant difference in total lizard captures between habitats was found.

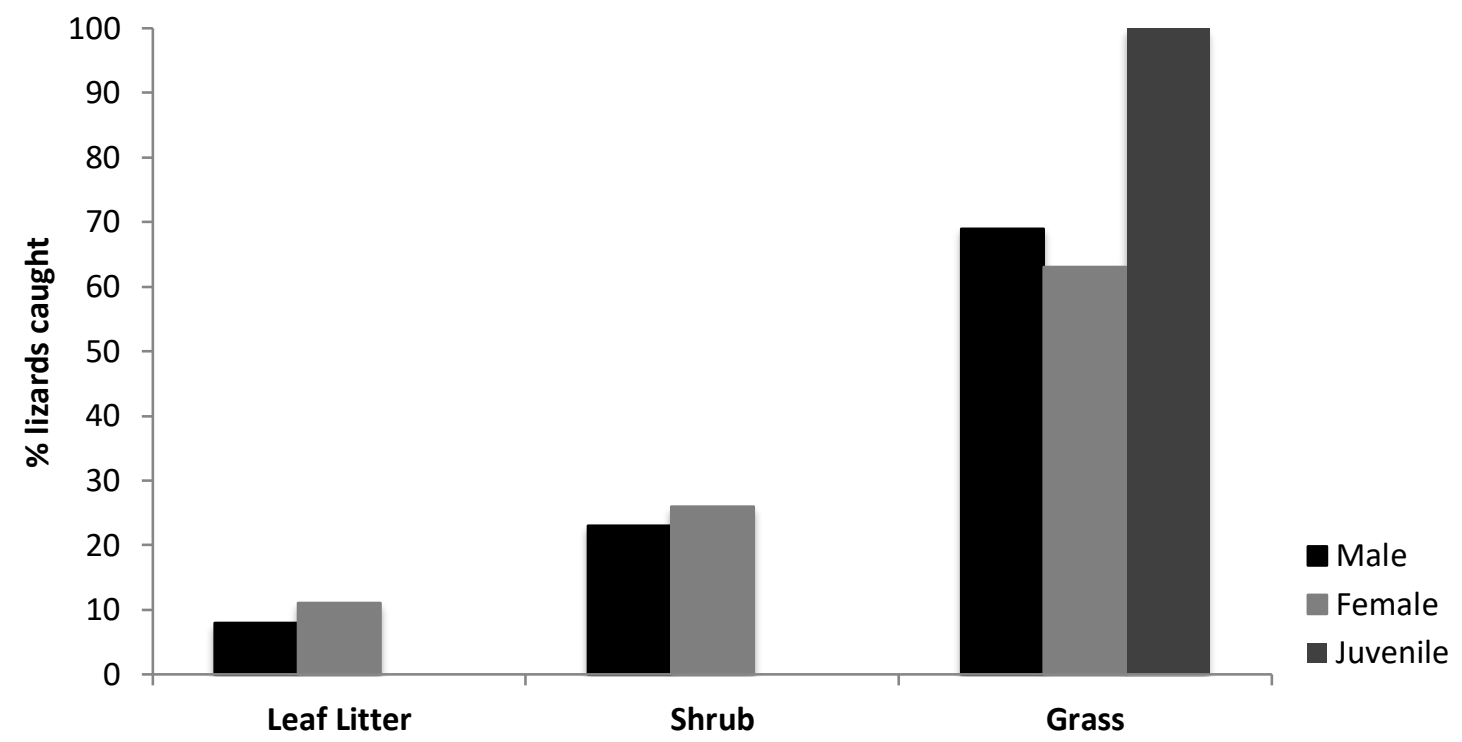

Figure 13: Percentage of male, female and juvenile captures in pitfall traps surrounded by each vegetation type on Maud Island. Male $N=13$, Female $N=19$, Juvenile $N=2$. There was no significant effect of vegetation type surrounding pitfall trap on age group trapped. 


\subsection{Discussion}

\section{Population estimates}

The weighted mean model estimated lizard densities to occur at as many as 6,020 individuals/ha and 1,528 individuals/ha on the private island and Maud Island respectively, while the MNA model produced much lower density estimates of 466/ha (SD 230) and 118/ha (SD 164). However, the potential violation of the assumption of equal catchability and the limitations of simple mark-recapture based models imply that the population numbers estimated in this study should be interpreted cautiously. Conservation objectives for the management of threatened animal species are often articulated in terms of population size (Lancia et al. 1994). However, population estimates for New Zealand lizard species are notoriously difficult due to their cryptic nature, unequal capture probabilities between individuals and territorial behaviour (Towns 1975). This individual heterogeneity within lizard communities can cause negative bias in commonly used estimators. For instance, estimates of gecko abundance can be severely underestimated due to their ability to escape pitfall traps. Additionally, small lizards may avoid traps (Towns \& Elliot 1996), resulting in underestimation of juvenile and small species abundances.

Furthermore, the MNA model can produce biased population estimates with counts disproportionate to actual population size, as it is sensitive to the low catchability of unmarked individuals (Efford 1992). As a result, population numbers attained using this method are commonly an underestimation of actual numbers (Efford 1992). Conversely, population estimators that utilise markrecapture, such as the weighted mean model, have a tendency to overestimate population numbers when recaptures are very low (Roff 1973), and standard errors for mark recapture models are strongly correlated with population estimates, resulting in often inaccurate and unreliable estimation of the true mean of a population (Begon 1979). More sophisticated models such as those available in mark-recapture software packages should be employed wherever possible to account for such variability. However, in cases where data are too deficient to employ more sophisticated methods of population estimation, a 
choice must be made as to whether insufficient data should be discarded entirely or if less accurate results are better than no results (Begon 1975).

Taking these limitations into account, there are clear differences in lizard population estimates and community structure between the private island and Maud Island. The private island maintains a considerably higher density of lizards than Maud Island (Tables 7; 8). The discrepancy in lizard densities could be due to differences in habitat between the islands; the private island vegetation consists largely of exotic pasture and low scrub, while Maud Island has a comparatively high proportion of regenerating forest. Many Oligosoma species are diurnal and display basking behaviour and therefore, are most often associated with comparatively open habitats such as those present on the private island (Gill 1976; Patterson 1992; Newman 1994). The gradual reforestation of Maud Island may have resulted in range contractions of diurnal skinks, ultimately reducing the population size. Similarly, reforestation efforts on Mana Island, New Zealand (East et al. 1995) and at the mainland New Zealand site, Pukerua Bay (Towns \& Elliot 1996) are predicted to significantly reduce range and abundance of $O$. nigriplantare polychroma.

Additionally, the recent mouse incursion on Maud Island could have the potential to reduce lizard numbers. Mice are known predators of New Zealand lizards (Tocher 2009) in addition to competing for the same resources (Reardon et al. 2012). For example, surveys of the McGregor's skink (O. macgregori) and W. maculatus populations on Mana Island demonstrated a significant increase in pitfall capture rates after mouse eradication (Newman 1994). However a survey of $O$. aeneum and $O$. nigriplantare polychroma populations post mouse eradication on Mana Island found no significant increase in these species (Newman 1994) It is unclear what effect the mice have had on the Maud Island lizard populations, as there is limited knowledge on lizard abundance and diversity prior to the incursion.

Although the private island appears to host a higher density of lizards, Maud Island has higher species diversity including three species of gecko. Notably, 
gecko species were absent from the private island, or occurred at numbers too low to detect in this study, although geckos are able to escape from pit fall traps so may not have been detected using this method. There is anecdotal evidence that geckos existed on the private island historically but were extirpated when kiore reached high densities (Sandra Cooke, pers. comm. 2014). Kiore are more active at night and so nocturnal or crepuscular ground dwelling species of lizard such as W. maculatus are most at risk from predation (Whitaker 1973). There have been sightings of a "green gecko" in a stand of trees on the northwest side of the private island (Sandra Cooke pers. comms.) but a search of this area during the day and spot light search during the night revealed no sign of any geckos. However, a more extensive survey of the private island is needed to better assess the species present.

Additionally, bias can be present in simple density indices as they are unable to account for variation in individual detectability and variable density over different habitats (Hare 2012). Although the private island vegetation is relatively homogeneous, Maud Island consists of a patchwork of different habitats, making extrapolation of density estimates to large areas difficult. However, despite this potential for bias, lizard densities for both the private island and Maud Island are similar to density estimates of other New Zealand sites. For example, a survey of the 0 . nigriplantare polychroma population at Birdlings Flat, Canterbury, estimated a density of 200-400 lizards/ha (Freeman 1997). In addition, a survey of lizard species present at Pukerua Bay estimated Oligosoma species densities of between 656 and 4919 lizards/ha, regardless of lizard predators present at this site (Towns \& Elliot 1996). Similar lizard density estimates at other New Zealand sites suggest that lizard densities estimated in this study are possible and even likely.

Species, sex ratios and age group proportions

Three species of skink were detected on the private island in this study, Oligosoma notosaurus, O. nigriplantare polychroma and O. stenotis. Oligosoma nigriplantare polychroma is distributed throughout New Zealand and $O$. 
notosaurus is common in Stewart Island archipelago. However, identification of Oligosoma stenotis on the private island is significant. Oligosoma stenotis is previously known only from Stewart Island, where they were originally mistaken for Leiolopisma nigriplantare polychroma (now Oligosoma) due to their similar morphology (Patterson \& Daugherty 1994). The discovery of this range extension emphasises the paucity of knowledge of New Zealand lizard species and their range and distribution.

Oligosoma notosaurus captured on the private island and O. zelandicum captured on Maud Island exhibited female biased sex ratios. These sex ratios may represent a real bias in 0 . notosaurus and 0 . zelandicum populations. Stochastic processes acting on small populations can cause sex bias (Flannagan 2000), but this is not uncommon in New Zealand lizard populations with female biased sex ratios found in natural populations of Woodworthia chrysosireticus (Flannagan 2000), Oligosoma nigriplantare polychroma (Freeman 1997), O. whitakeri and $O$. alani (Towns \& Ferreira 2001). Female biased sex ratios in lizards are not always detrimental to population persistence. For example, selection of female biased groups of lizards for translocation is a common management technique in New Zealand as it increases the probability of reproductive success in introduced populations (Towns \& Ferreira 2001). Alternatively, the sex bias encountered in this study may be an artefact of female specific behaviours such as the increase in basking behaviour associated with pregnancy in skinks (Schwarzkopf \& Shine 1991). A high proportion of females sampled in this study were pregnant and if pitfall grids were situated near basking areas it is likely that a higher proportion of females would encounter traps due to their increased basking activity.

In addition to biased sex ratios, both the private island and Maud Island had disproportionately low captures of juvenile lizards to adult lizards ( 0.16 and 0.06 of total captures respectively). This may suggest a real age group bias in the populations due to low survivorship of juveniles but could also be explained by trap avoidance by smaller lizards, a higher proportion of basking females in trapping areas or a combination of these factors. 


\section{Site fidelity}

Three of the 0 . notosaurus recaptured on the private island were found in the traps they had originally been caught in. This result may be indicative of strong site fidelity. Site fidelity is common in New Zealand lizard species. For example, a mark recapture survey at Pukerua Bay found that 0 . zelandicum, O. nigriplantare and $W$. maculatus were rarely recaptured more than four metres from their original capture site (Towns \& Elliot 1996), and a survey of $O$. grande and $O$. otagenese individuals in Otago found strong site fidelity with the majority of individuals moving less than 9 metres from where they were originally sighted (Coddington \& Cree 1997). In contrast, one adult male on the private island travelled 142 metres from the original trapping site in one day but it is not uncommon for lizard species that typically display strong site fidelity to travel long distances. For example, an O. aenea individual was observed 64 metres from its original capture site at Pukerua Bay (Towns \& Elliot 1996) and an O.grande was recorded $139 \mathrm{~m}$ from where it was original sighted (Coddington \& Cree 1997). The recapture data from the private island might suggest that lizard species at this site do display strong site fidelity but will move out of their home range, perhaps in search of mating or resource opportunities. Alternatively, handling during sample could result in trap aversion and influence dispersal behaviour. Lizard movement over long distances has implications for the transmission of disease between lizard populations and sympatric species. Strong site fidelity might restrict the spread of infectious disease such as Salmonella to lizard populations and other species within a small area. However, if infected lizards commonly travel long distances in search of new territory or mating opportunities, the risk of disease transmission to lizards, other sympatric species and environmental sources may extend to neighbouring areas. The risk of disease transmission by infected lizards over large areas may be highest during summer when mate-searching behaviour occurs most frequently. Further investigation of lizard site fidelity on the private island is necessary to determine if a seasonal pattern of long distance movement exists. 


\section{Morphology}

Average SVL measurements of skink species found on both the private island and Maud Island are roughly comparable to previously recorded measurements from other predator-free island sites within New Zealand and marginally larger than the same species found at mainland sites (Table 6).

\begin{tabular}{|c|c|c|c|c|}
\hline Species & Study site & $\begin{array}{l}\min -\max \\
\mathrm{SVL} / \mathrm{mm}\end{array}$ & Island SVL comparison & Mainland comparison \\
\hline $\begin{array}{l}\text { O. nigriplantare } \\
\text { polychroma }\end{array}$ & private island & $51-70$ & $\begin{array}{l}\text { 77mm maximum, Stewart Island } \\
\text { (Patterson \& Daugherty 1990) }\end{array}$ & $\begin{array}{l}\text { 58mm ave, Birdlings Flat (Freeman } \\
\text { 1997) }\end{array}$ \\
\hline O. notosaurus & private island & $42-70$ & $\begin{array}{c}\text { 75.5mm maximum, Stewart and } \\
\text { Codfish Islands (Patterson \& } \\
\text { Daugherty 1990) }\end{array}$ & Not known on the mainland \\
\hline O. stenotis & private island & $52-64$ & $\begin{array}{l}\text { 74.5mm maximum, Stewart Island } \\
\text { (Patterson \& Daugherty 1994) }\end{array}$ & Not known on the mainland \\
\hline O. zelandicum & Maud Island & $51-72$ & data unavailable & $\begin{array}{l}\text { 54.1mm maximum SVL, Manawatu (Gill } \\
1976 \text { ) }\end{array}$ \\
\hline W. maculatus & Maud Island & $58-74$ & $\begin{array}{l}66.2 \mathrm{~mm} \text { average, Mana Island } \\
\text { (Monks \& Rose unpub. data 2013) }\end{array}$ & $\begin{array}{c}\text { 51.1mm ave SVL, Pukerua Bay (Monks } \\
\text { \& Rose unpub. data 2013) }\end{array}$ \\
\hline
\end{tabular}

Table 6: Comparison of lizard SVL from other island and mainland sites.

\section{Effect of temperature on capture rates}

Lizard capture rates on the private island were positively correlated with the maximum air temperature on the day of capture. In contrast, there was not a strong correlation between lizard capture rates and air temperature on the day of capture on Maud Island. Emergence behaviour of diurnal skinks is extremely weather dependent due to their heliothermic physiology (Roughton \& Seddon 2006; Coddington \& Cree1992). Higher air temperatures provide better basking opportunities and hence, skinks are more active, and more likely to be captured under these conditions. Lizards may be more responsive to temperature fluctuations on the private island due to its generally cooler climate and may exploit warmer weather more quickly than lizards on Maud Island where 
temperatures are higher. Conversely, the capture rates of nocturnal lizard species such as W. maculatus can be negatively associated with air temperature (Hare 2012). As a result of this temperature associated capture variability, variation in temperature over lizard sampling periods can greatly influence population estimates and this variation should be accounted for when estimating lizard population numbers. However, lizard recapture rates were too low in this study to apply more sophisticated population models to account for temperature variability and as a result, population estimates reported should be interpreted cautiously.

\section{Effect of vegetation type on lizard capture rates}

There was no significant effect of vegetation type on lizard capture rates on either the private island or Maud Island. Analyses of capture numbers according to vegetation type were averaged over all lizard species in this study as accurate, species-specific analyses of lizard habitat preference were not feasible for most species due to low sample sizes and recapture rates. However, Oligosoma notosaurus was found in approximately equal numbers in grass (81 lizards) and shrub (80 lizards) habitats. Habitat type plays a large role in lizard species densities and distribution as many species have very different ecological requirements (See species descriptions section). However, variation in density and distribution of different lizard species may also be attributed to factors such as resource competition, moisture and territoriality (Freeman 1996). Therefore, it is likely that habitat preference does have an effect on lizard density and distribution on the private island and Maud Island but the sample size in this study was too low to detect any trends.

The information gained from this study provides valuable insights in the distribution, density and diversity of lizard population occurring within takahē territories on the private island and Maud Island. Lizard population and density estimates reported here provide an indication of how lizards might play an important role in island ecosystem functions. Investigation of habitat occupancy provides a starting point for informing decisions regarding the effects of 
vegetation restoration on lizard populations on the private island and Maud Island. Additionally, this study constitutes the first lizard inventory for the private island and the discovery of a range extension of Oligosoma stenotis will help to inform future management decisions regarding this naturally uncommon species (Hitchmough et al. 2013). Finally, the density of skinks discovered in this study provide a clear indication that lizards are abundant on the private island and Maud Island and have the potential to act as a Salmonella reservoir at these sites. Although Salmonella has not yet been detected on Maud Island, the translocation of Salmonella infected takahē to this site is a very real threat both to resident takahē and lizard populations. 
Chapter 3: Are skinks the Salmonella reservoir in the takahe translocation network? 


\subsection{Introduction}

Pathogens play an important role in the ecology of their wild host species, potentially affecting health, reproductive output and even survival of infected organisms (Holt et al. 2003). However, the role that pathogens play in structuring wildlife populations and communities is sporadically documented (Griffith et al. 1993). The dynamics of disease in wildlife populations often involve a complex relationship between physiological, environmental and ecological variables (Holt et al. 2003), rendering elucidation of pathogen transmission pathways problematic. Not only do pathogens affect primary host species, non-specific pathogens can spill over to sympatric species, creating the potential for increased host availability (Anderson et al. 1986; Smith et al. 2009). Additionally, many pathogens are able to survive outside of a living host for extended periods of time (Flint 1987; Holley et al. 2006), increasing the likelihood of contact with new hosts and thus increasing pathogen persistence in wildlife communities. Defining the pattern of pathogen infection between primary hosts, sympatric species and their environments is crucial in the understanding of potential impacts a pathogen may have on its host species (Cunningham 1996). In the current climate where species are increasingly threatened by decline, understanding the role pathogens play in structuring wildlife communities is imperative to conservation and management efforts.

The translocation of animals has become a common technique in conservation management (Woodford 1993). Groups of animals are commonly moved to predator free offshore or mainland islands in an effort to conserve wildlife threatened by habitat loss and introduced predators (Hitchmough et al. 2010). For example, in New Zealand alone, over 3,000 official translocations of native terrestrial species have been carried out for conservation purposes since 1894 (Sherley et al. 2010). However, the movement of any concomitant organisms with species targeted for translocation is inevitable and co-introduced pathogens have the potential to negatively impact both the managed species and sympatric species at the translocation site (Cunningham 1996). A translocated animal may carry a pathogen with no apparent negative effects but transmission of the pathogen to immunologically naïve hosts at the site of translocation may result 
in disease (Viggers et al. 1993). For example, the introduction of domestic avian stock infected with avian pox to Hawaii in the 1800s caused widespread disease and extinction in the endemic avifauna already present at the site of translocation (van Riper et al. 2002).

Conversely, translocated animals may be exposed to foreign pathogens in their new environment (Viggers et al. 1993). For example 19 kakapo (Strigops habroptilus), an endangered flightless parrot endemic to New Zealand, were translocated to Chalky Island from Codfish Island in 2004, all birds having undergone routine disease screening for Salmonella, Yersinia and Campylobacter prior to translocation (Gartrell et al. 2005). Three of the birds died within 72 hours of transfer from Erysipelothrix rhusiopathiae, an infection potentially transmitted to the kakapo from sea birds in residence at the site of translocation. Additionally, the physiological stress associated with capture and translocation of animals may diminish immune competence and hence resistance to disease, potentially allowing pathogens to cause disease in infected animals involved in the translocation process (Teixeira et al. 2007). Very little is known about pathogens of native species, or sources of infection in New Zealand wildlife populations. I investigated environmental factors that may influence the transmission and prevalence of Salmonella in the New Zealand endemic bird, the takahē.

\section{Takahē (Porphyrio hochstetteri)}

The takahē is a critically threatened species with only 227 adult birds remaining. Small, geographically isolated populations of takahē now persist solely on predator free offshore islands and mainland sanctuaries (Fig. 1) and as a result, translocation is routinely employed to maintain genetic diversity and ensure breeding success (Jamieson \& Briskie 2006). 


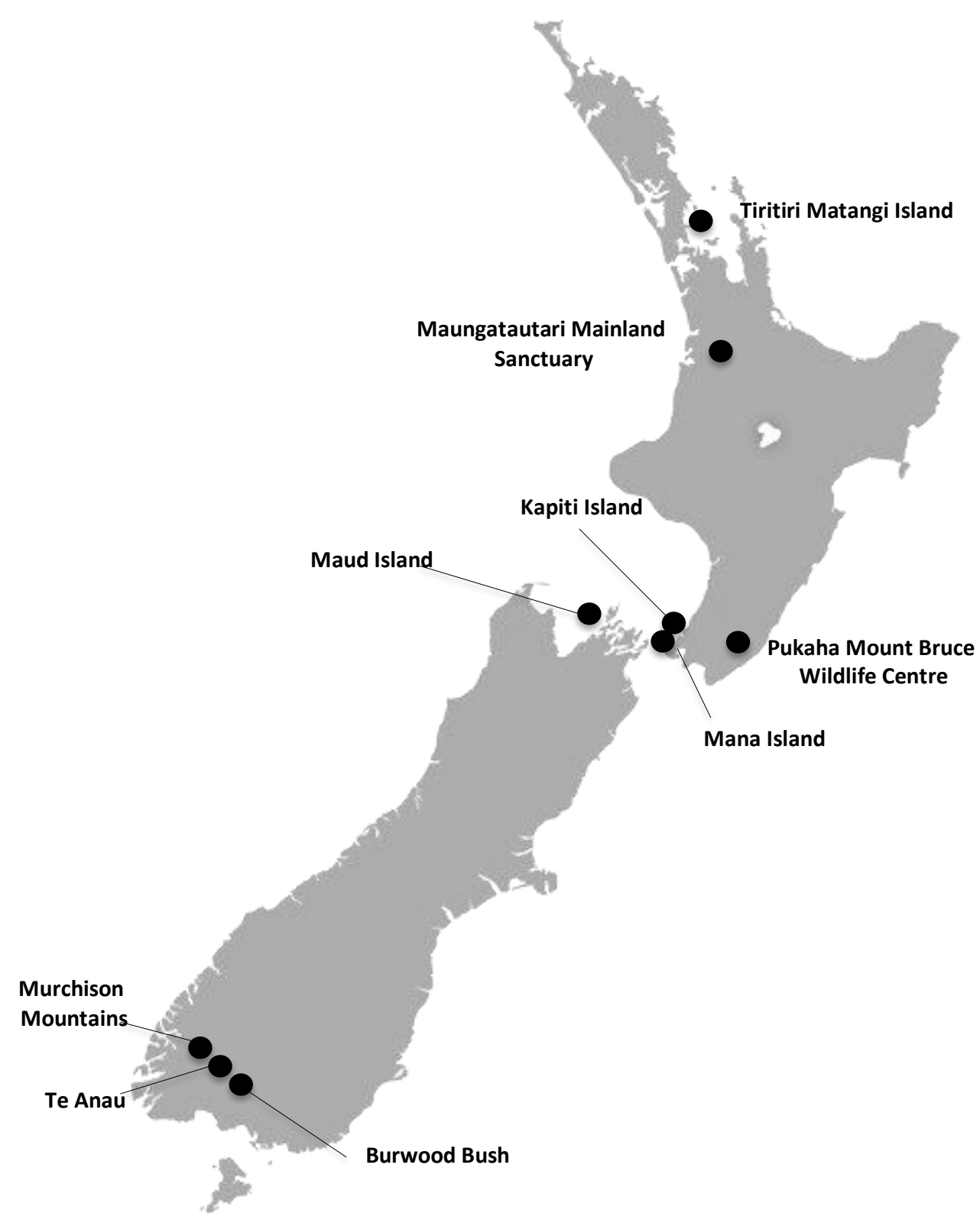

Figure 1: Map of New Zealand showing free-ranging populations of takahē (Murchison Mountains, five offshore islands and one mainland sanctuary) and captive populations of takahē (Te Anau, Burwood and Pukaha Mount Bruce) (Wickes et al. 2009). Location of the privately owned Southland Island not disclosed for security reasons.

Birds are routinely screened for the presence of pathogens during translocation to mitigate disease outbreaks (McInnes et al. 2004). Additionally, takahē selected for translocation are quarantined at the Burwood Bush takahē rearing facility in Te Anau before being moved to other sites, making the Burwood Bush site an important hub in the translocation network (Grange et al. 2014). 
In an investigation of disease in the takahē translocation network, Salmonella mississippi and Salmonella houtenae were isolated for the first time from the takahē population on a privately owned southland Island during disease screening (this island is unable to be identified for security reasons) (Grange pers. comm. 2015). An infected bird was moved from the private island to the Burwood Bush takahē rearing facility for quarantine prior to translocation. Subsequently, Salmonella Saintpaul was isolated from this bird, which had tested positive for S. mississippi a week earlier. Salmonella Saintpaul, S. mississippi and S. houtenae had not been isolated previously from takahē during routine disease screening for translocation. The isolation of novel Salmonella serovars from the private island takahē population is indicative of the presence of a Salmonella reservoir on the private island. Additionally, the isolation of Salmonella Saintpaul from the bird after having been moved to Burwood Bush could indicate another source of Salmonella at the rearing facility.

\section{Salmonella}

Comprised of two species (Salmonella enterica and S. bongori), Salmonella bacteria currently have over 2500 described serovars (Mermin et al. 2004). While some serovars such as $S$. typhi display host specificity, infecting only humans, others are host generalists and are capable of infecting a wide range of species (McClelland et al. 2001). Therefore, Salmonella are considered important pathogens for both humans and animals (Woodward et al. 1997; Mermin et al. 2004), with many serovars possessing the propensity for interspecies transmission.

Salmonella transmission most often occurs through the faecal-oral route entering the host via the gastrointestinal tract (Gopinath et al., 2012). Once the gut has been colonized, the bacterium then translocates to the host's systemic tissues and can be shed either persistently or intermittently via the faeces (Gopinath et al. 2012). Salmonellosis is defined by symptoms ranging from gastroenteritis, bacteremia and even death (Acheson \& Hohmann, 2001). However, infected hosts may or may not develop clinical disease, with 
pathogenesis often reliant on host immunosuppression (Acheson \& Hohmann, 2001; Tizard, 2004). Because Salmonella does not always eventuate in clinical symptoms, healthy carriers can act as Salmonella reservoirs, playing an important role in the transmission of this bacterium (Giovannini et al., 2013).

One of the serovars isolated from takahe on the private island (Salmonella mississippi) had previously been isolated from reptiles in New Zealand (Middleton et al. 2014) and Salmonella Saintpaul is also commonly a reptileassociated serovar (De Hamel \& McInnes 1971). Additionally, takahē on the private island had been observed hunting and consuming skinks. Direct contact with infected lizards through consumption or indirect contact with lizard faeces could result in transmission of Salmonella to takahē, further indicating that the lizard population on the private island may provide a potential Salmonella reservoir.

Salmonella is now known to be a common component of reptile intestinal gut flora (Kingsley et al. 2000; Warwick et al. 2001) with at least $40 \%$ of all Salmonella serovars cultured predominantly from reptiles (Mermin et al. 2004). Many lizards carrying Salmonella remain asymptomatic (Kingsley et al. 2000; Onderka \& Finlayson 1985), as Salmonella is commonly restricted to the gastrointestinal tract of reptiles with no extraintestinal spread (Sheelings et al. 2011). However, conditions of physiological stress can cause the bacterium to manifest as clinical disease (Sheelings et al.2011).

Little is known about the pathogenicity of Salmonella in free-living New Zealand lizards (Middleton et al. 2010). However, surveys of Salmonella prevalence in New Zealand lizard populations (Middleton et al. 2010; 2014) found no loss of individual body condition associated with Salmonella carriage, indicative of an asymptomatic carrier state. The persistence of virulent pathogens in an environment is often attributed to the presence of asymptomatic carriers such as reptiles (McCallum 2012). If a pathogen causes mortality in its target host, it will eventually extinguish itself when the host population falls below a certain level (McCallum 2012). However, a pathogen can persist in an animal community by 
utilising healthy carriers as vectors (McCallum 2012; Viggers et al. 1993). The capacity for reptiles to harbour Salmonella as part of their intestinal flora without showing signs of clinical disease could increase the likelihood of endemic lizards acting as a competent Salmonella reservoir on the private island.

There is limited literature available on the prevalence of Salmonella in the wild reptiles of New Zealand, but routine disease screening of lizards for translocation within the Hauraki Gulf, New Zealand revealed faecal excretion of Salmonella enterica subspecies IV 40:g,t:- in three skink species (Oligosoma smithi, 0 . moco and $O$. aeneum) and one common gecko (Hoplodactylus maculatus) (Baling et al. 2013). This was the first record of Salmonella subspecies IV in New Zealand reptiles, emphasising the lack of baseline information available on Salmonella infection in New Zealand lizards. In addition, a survey carried out by Middleton et al. (2010) examined the prevalence of Salmonella in endemic lizards on eight offshore New Zealand islands, finding the mean test prevalence of Salmonella in lizard populations on the islands to be between $0-9.9 \%$. A total of 11 Salmonella serovars were isolated from lizard populations on five of the eight islands including 29 from sub species I (subsp. enterica), and five from subspecies IV (subsp. houtenae). This study found that the majority of Salmonella was isolated from skinks (family Scincidae). Additionally, Salmonella was isolated from $6.5 \%$ of skinks from the Oligosoma genus in a survey of the lizard population on Stephens Island, New Zealand (Middleton et al. 2014). In contrast, two surveys of Salmonella prevalence in a population of the endemic tuatara (Sphenodon punctatus), found a Salmonella prevalence of zero (Gartrell et al. 2007; Middleton et al. 2014).

Similarly to takahē, many endemic New Zealand lizard species are now restricted to predator free offshore islands (Towns \& Daugherty 1994). All five islands where takahē populations are managed (Private, Mana, Tiritiri Matangi, Kapiti and Maud Islands) are also residence to free-living endemic lizard populations (New Zealand Herpetological Society, 2014) potentially acting as Salmonella reservoirs. In the 2010 Middleton study, lizards were surveyed for faecal excretion of Salmonella on two of the islands that are also inhabited by takahē 
populations, Mana Island off the west coast of Wellington and Maud Island in the Pelorus Sound. Salmonella Mana was isolated from one skink (Oligosoma nigriplantare) and one gecko (Hoplodactylus maculatus) on Mana Island. The same serovar had been isolated in takahē on Mana Island for the first time in 1998 (ESR 2010). The isolation of a concurrent Salmonella serovar in the lizard and takahē populations on Mana Island indicates that further investigation of the potential for lizards to act as Salmonella reservoirs in the takahē translocation network is warranted. Conversely, no lizards tested positive for Salmonella serovars on Maud Island. However, a maximum possible Salmonella prevalence of $22.0 \%$ was estimated for Maud Island indicating that Salmonella might still occur at a lower prevalence than detectable by sample sizes used in the study (Middleton et al. 2010).

Although the carrier state remains the principal foundation for Salmonella transmission between species (Gopee et al. 2006), it can persist in the environment for extended periods of time. While Salmonella typically achieves optimal growth at between $35-37^{\circ} \mathrm{C}$, serovars have been reported to grow in temperatures as low as $5.5^{\circ} \mathrm{C}$ (Matches \& Liston 1968) allowing it to survive in range of environments and climates. The capacity for Salmonella to survive independently of a host allows infectious species of Salmonella to further exploit transmission strategies by increasing the likelihood of contact with potential hosts whilst still viable (Holley et al. 2006).

Salmonella has been reported to maintain viability after over 300 days in soil under ideal conditions (Holley et al., 2006) and evidence of Salmonella survival in the New Zealand environment is found in the estimate of Salmonella Saintpaul prevalence of $8.4 \%$ from 50 soil samples taken from Stephens Island (Middleton et al. 2014). Takahē may be particularly vulnerable to contact with environmental sources of Salmonella, as they are primarily grass and tussock grazers. In winter months they often rely on underground rhizomes to supplement their diet (Mills et al. 1980), increasing the probability of coming into contact with Salmonella residing in the soil. 
In addition, long-term survival of Salmonella in water sources is well documented (Bjergbaek \& Roslev, 2005; Jacobsen \& Bech, 2012). Salmonella has been shown to survive in pond water for up to 115 days and in animal faeces for 30 months (Johnson-Delaney 1996). Water sources within takahē territories on the private island are most likely used by sympatric wildlife, and faecal contamination of these water sources could result in transmission of Salmonella to takahē. Although intensive management of takahē means that water sources are provided and replenished within takahē territories, the private island is only accessible by helicopter, limiting opportunities for cleaning and refilling these water sources.

Salmonella infection has been linked with mortality in several bird species worldwide. Over 68,000 wild bird deaths were attributed to Salmonella between 1985 and 2004 in the United States (Hall \& Saito 2004), while a seasonal pattern of mass Salmonella-induced death is seen annually in the finch population throughout Britain (Robinson et al. 2010). More recently, there have been reports of Salmonella related mortality in New Zealand's wild bird community. In 2000 an unusually high number of sparrow (Passer domesticus) mortalities occurred throughout the country (Alley at al. 2002), in addition to sporadic mortality in other passerines including the native silver eye (Zosterops lateralis) (Alley et al. 2002). Additionally, a 2006 outbreak of Salmonella caused mortality in as much as $30 \%$ of an island population of hihi (Notiomystis cincta), a New Zealand endemic passerine (Ewen et al. 2007). Notably, hihi are highly endangered and limited to small sanctuary populations (Ewen et al. 2007), emphasising the potential risk that Salmonella infection poses to threatened bird species such as the takahē.

The infected takahē from the private island exhibited no obvious clinical signs of disease from Salmonella infection. However, because the serovars have not previously been isolated from takahē, the ultimate physiological effects of infection are difficult to predict. Additionally, takahē from the private island represent an important source of birds for contribution to the takahē translocation network. The introduction of Salmonella infected birds to 
immunologically naïve takahē populations through translocation could pose significant health risks to the larger takahē population. Therefore, understanding the dynamics and extent of Salmonella infection and transmission within the takahē translocation network is crucial to the management and conservation of takahē.

The aims of this chapter are to:

1. Investigate the prevalence of Salmonella in the lizard populations, soil and water sources within takahē territories on the private island, Maud Island and the Burwood Bush takahe rearing facility.

2. Assess whether lizard densities or environmental variables can predict Salmonella presence within takahē territories.

3. Determine whether any Salmonella serovars found in this study concur with those isolated from takahē. 


\subsection{Methods}

\section{Collection of samples}

\section{Lizard samples}

All lizards were sampled from within takahē territories on the private island and Maud Island during the Southern hemisphere summer in January 2013 and February 2013 respectively. These territories were delineated with the aid of Department of Conservation staff and island caretakers. I collected cloacal swabs from 50 lizards from the private island and 30 lizards from Maud Island to screen for Salmonella species. No lizards were detected for sampling inside quarantine pens at the Burwood Bush takahē rearing facility (Phil Marsh pers. comm., 2014). I primarily sampled lizards caught in pitfall traps (see Chapter Two), however I also sampled hand-caught lizards on Maud Island where pitfallcaught lizard numbers were low. Cloacal swabs were collected using Minitip swabs and stored for transport in individual tubes containing Aimes agar gel with charcoal (Copan Diagnostics Inc., 2175 Sampson Ave, Suite 124, Corona, CA92879, USA). Cloacal swabs were refrigerated at $4^{\circ} \mathrm{C}$ for a maximum of nine days prior to culture. Lizard density of each site sampled was determined from total captures (Chapter Two) and assigned the value of high (38-41 lizards), medium (17-20 lizards) or low (12-13 lizards).

\section{Environmental samples and variables}

I selected sites for environmental sampling within each takahē territory for both their proximity to water sources and takahē feeders. This was to maximise the likelihood of sampling areas where takahē traffic had recently been high and hence, detection of takahē associated Salmonella would be enhanced. I categorised each water source frequented by takahē within a given territory as either natural or artificial. Artificial water sources on the islands are rainwaterfed tank and trough systems, which are topped up manually by island staff intermittently. Water sources were classified as natural if they consisted of a stream or pond fed by a natural stream. I collected $500 \mathrm{mls}$ of water in sterile 
containers directly from the main water source in each territory to culture for Salmonella species.

Soil samples were collected from areas directly adjacent to takahē water samples by rubbing a sterile swab over the surface of a $50 \mathrm{~cm}^{2}$ patch of soil directly underneath each takahē-feeding hopper. Swabs were then transferred directly to $400 \mathrm{mls}$ of sterile buffered peptone water for storage and transport. Substrate type was divided into the two main groups present in takahē territories on the private island, "hydric" if the predominate soil in a takahē territory had poor drainage and was saturated with water at the time of sampling, or "non-hydric" if well aerated with relatively good drainage. Water and soil samples were collected in this manner from the six quarantine pens and two brood pens at Burwood Bush takahē rearing unit. Environmental samples were collected on the last day of each trip and refrigerated to minimise sample degradation prior to culture.

\section{Culture}

Enteric bacteria typically attain ideal growth when incubated at $37^{\circ} \mathrm{C}$ but there is the possibility that some reptile associated serovars of Salmonella have adapted to the lower body temperature consistent with cold-adapted reptiles (Bronikowski et al. 2001). To allow for the cooler body temperature of lizards, each sample was incubated at $28^{\circ} \mathrm{C}$ and $37^{\circ} \mathrm{C}$.

Cloacal swabs were chopped into $2 \mathrm{ml}$ Phosphate Buffered Saline (PBS) and agitated using a vortex mixer. The PBS solution $(500 \mu \mathrm{L})$, was then inoculated into $20 \mathrm{ml}$ Buffered peptone water (BPW) and incubated at both $28^{\circ} \mathrm{C}$ and $37^{\circ} \mathrm{C}$ for 24 hours. All samples were initially incubated in non-selective pre enrichment media (BPW) to allow revival and proliferation of any bacteria present. Water samples were centrifuged and the resulting pellet re-suspended in $20 \mathrm{ml} \mathrm{BPW}$ for incubation at both temperatures, while soil samples were split into two and incubated in their existing BPW. 
I then used two selective enrichment broths, Rappaport-Vassiliadis soya peptone (RVS) and Tetrathionate/iodine (TET) for all samples, to improve isolation of potential Salmonella species. Pre-enrichment culture was inoculated into the selective enrichment broths and RVS broth samples were then incubated at both $42^{\circ} \mathrm{C}$ and $28^{\circ} \mathrm{C}$ for 24 hours while the TET broth samples were incubated at $37^{\circ}$ $\mathrm{C}$ and $28^{\circ} \mathrm{C}$.

After incubation, the RVS and TET were streaked onto selective growth media Xylose Lysine Deoxycholate (XLD) and Brilliant Green Modified (BGM) agar plates for subcultivation. These samples were incubated at $37^{\circ} \mathrm{C}$ and $28^{\circ} \mathrm{C}$ for 18-24 hours.

Typical Salmonella colonies grow on XLD agar with well-defined black centres from $\mathrm{H}_{2} \mathrm{~S}$ production and a pale yellow or red transparent halo (Fig. 2). Suspect colonies were identified visually for subculture onto MacConkey agar, and then incubated at their respective temperatures for 18-24 hours.

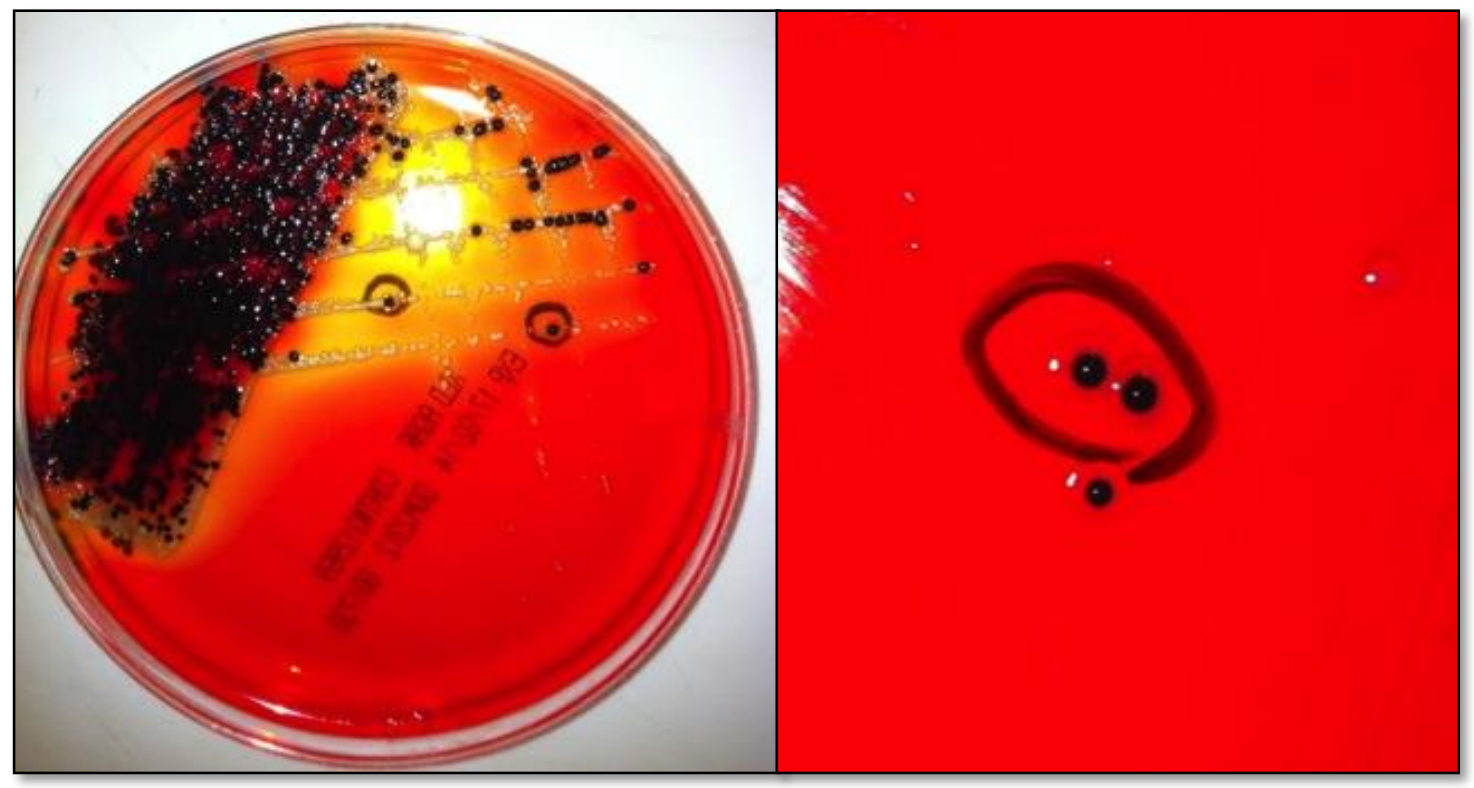

Figure 2: Examples of typical suspected Salmonella colonies selected for subculture. Salmonella colonies on XLD typically present with well-defined black centres with transparent red or yellow halos (Photo S. Rose). 


\section{Confirmation}

Triple Sugar Iron agar (TSI) and Lysine Iron Agar (LIA) slants were inoculated with grey colonies from the MacConkey agar and incubated at their respective temperatures for 18-24 hours. TSI presumptive positive cultures presented with alkaline slopes (red), acid butts (yellow) and with or without $\mathrm{H}_{2} \mathrm{~S}$ production (blackening). LIA presumptive positive cultures presented with alkaline slopes (purple) and alkaline butts (purple). Any LIA cultures with alkaline butts were considered potential Salmonella positive samples regardless of TSI reaction.

An oxidase strip test was then used to establish whether samples were of gramnegative bacteria and hence, likely to be Enterobacteria. A positive control of Salmonella typhimurium culture was used to confirm test efficacy. All oxidase negative samples proceeded to biochemical identification.

All presumptive Salmonella positive cultures were subject to broad scale serotyping using polyvalent flagella (poly-H) and polyvalent somatic (poly-O) slide agglutination tests to determine presence of Salmonella. Distinct clumping or agglutination of either polyvalent antiserum after 60 seconds of the test commencement was considered a positive antigen-antibody interaction. Positive isolates were then subcultured onto blood agar and incubated at their initial culture temperatures for 18-24 hours before further biochemical testing using the RapID ONE ${ }^{\circledR}$ system (Thermo Fisher Scientific, 12076 Santa Fe Drive, Lenexa, KS 14428, USA).

Suspensions were prepared from blood agar colonies and RapID ${ }^{\circledR}$ inoculation fluid and turbidity adjusted to the number two McFarland standard. After inoculation, test strips were incubated at $37^{\circ} \mathrm{C}$ for four hours before interpretation. Salmonella positive samples were subcultured to Dorset egg slopes and incubated at their initial culture temperatures for 18-24 hours. Samples were then sent to Environmental Science and Research in Wallaceville, Upper Hutt for definitive typing. 
Statistical analyses

\section{Prevalence}

True prevalence of Salmonella in the lizard population from the private island was calculated using methods defined in Thrusfield (2005) using values for point and test prevalence. Values for test sensitivity and specificity were obtained from a similar Salmonella isolation technique and assumed to be $50 \%$ and $98 \%$ respectively (Middleton et al. 2010; Bager and Petersen 1991).

Point Prevalence

$$
P=\frac{\text { number of individuals having disease at a particular point in time }}{\text { number of individuals at risk of disease at that point in time }}
$$

True Prevalence

$$
\hat{p}=\frac{p^{t}+\beta-1}{\alpha+\beta-1}
$$

where $\hat{p}=$ true prevalence,

$p^{t}=$ apparent prevalence

$\beta=$ specificity and

$\alpha=$ sensitivity

Values of sensitivity and specificity were obtained from a similar study by Bager \& Petersen (1991) and were assumed to be 50\% and 98\% respectively.

Test prevalence

$$
\rho^{t}=(P \times \alpha)+((1-P) \times(1-\beta))
$$


Variance

$$
\frac{\left(\rho^{t}\left(1-\rho^{t}\right)\right)}{\left(\eta(\alpha+\beta-1)^{2}\right)}
$$

where $\eta=$ population size estimated from chapter two.

95\% Confidence Interval

$$
\hat{\rho} \pm 1.96 \sqrt{\text { variance }}
$$

The Detection of Disease programme of online epidemiology software WinEpi (Working in Epidemiology, Facultad de Veterinaria, Universidad de Zaragoza, Spain) was used to estimate prevalence of Salmonella in the lizard population on Maud Island. This function allows the estimation of maximum possible prevalence of a pathogen in a population where no positive samples are obtained. For this analysis I used population size estimates from the minimum number alive and weighted means models calculated in chapter two of between 44 and 440 individuals per hectare respectively.

\section{Environmental Variables}

Fisher's Exact Test was used to evaluate the relationship between environmental variables and Salmonella positive soil, water and lizard samples taken from each takahē territory on the private island. The test included lizard density, substrate type and water source type at each site as explanatory variables and Salmonella positive or negative results as the dependent variable (Table 1). The analysis was performed in SPSS (SPSS Inc., Chicago IL). 


\subsection{Results}

\section{Salmonella on Southland Island}

Of the 50 cloacal swabs taken from the private island lizards, Salmonella houtenae ser. 40: g,t:- was isolated from one skink (Oligosoma notosaurus) (Fig. 4). Point estimate of the true prevalence of Salmonella carriage in the lizard population was calculated to be $2 \%$ and true prevalence between 2 and $11.8 \%$ (95\% C.I). Salmonella houtenae ser. 40: g,t:- was isolated from $25 \%$ of water samples, one artificial and the other from a natural stream, while Salmonella mississippi was isolated from 50\% of soil samples (Fig. 5). Both Salmonella houtenae and S. mississippi were isolated from takahē territory $\mathrm{F}$ water and soil samples respectively (Fig. 6). Fisher's Exact Test showed no significant association between Salmonella positive lizard samples and lizard density per takahē territory $(\rho=0.500)$, between Salmonella positive soil samples and substrate type within takahē territories $(\rho=0.786)$ or between Salmonella positive water samples and water source type found in the takahē territories $(\rho=0.643)$.

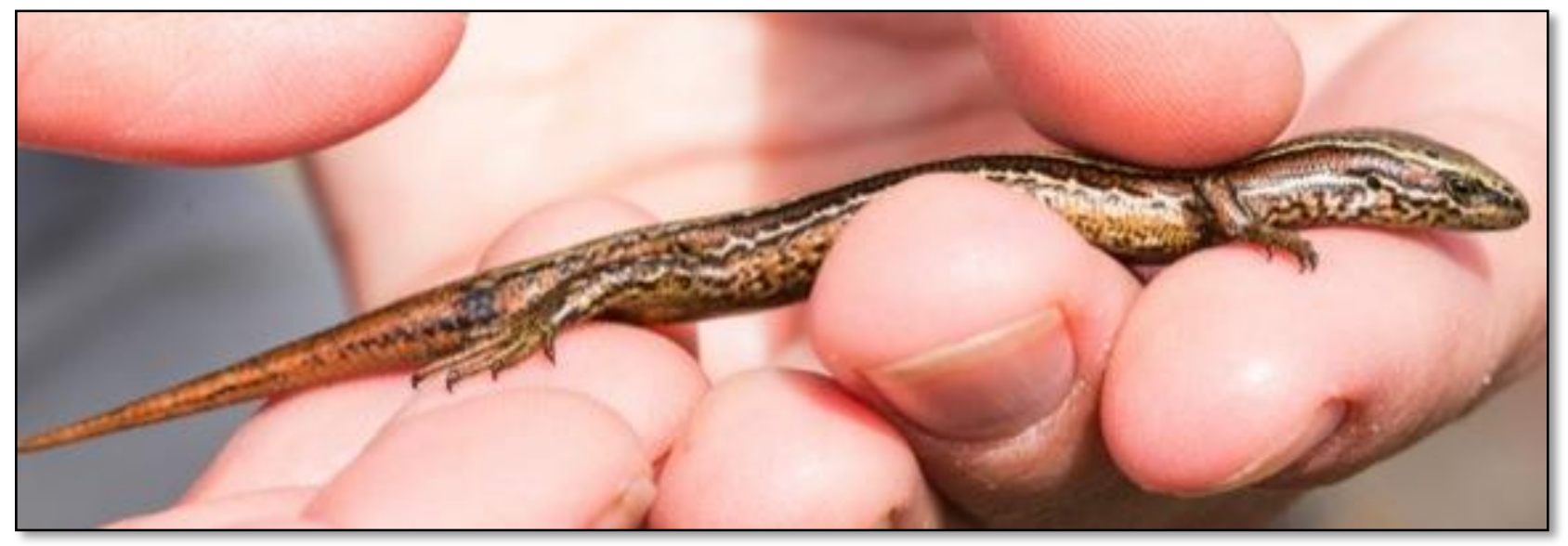

Figure 4: Oligosoma notosaurus (Southland skink) on the private island. Salmonella houtenae was isolated from this species (Photo by Thomas Burns). 


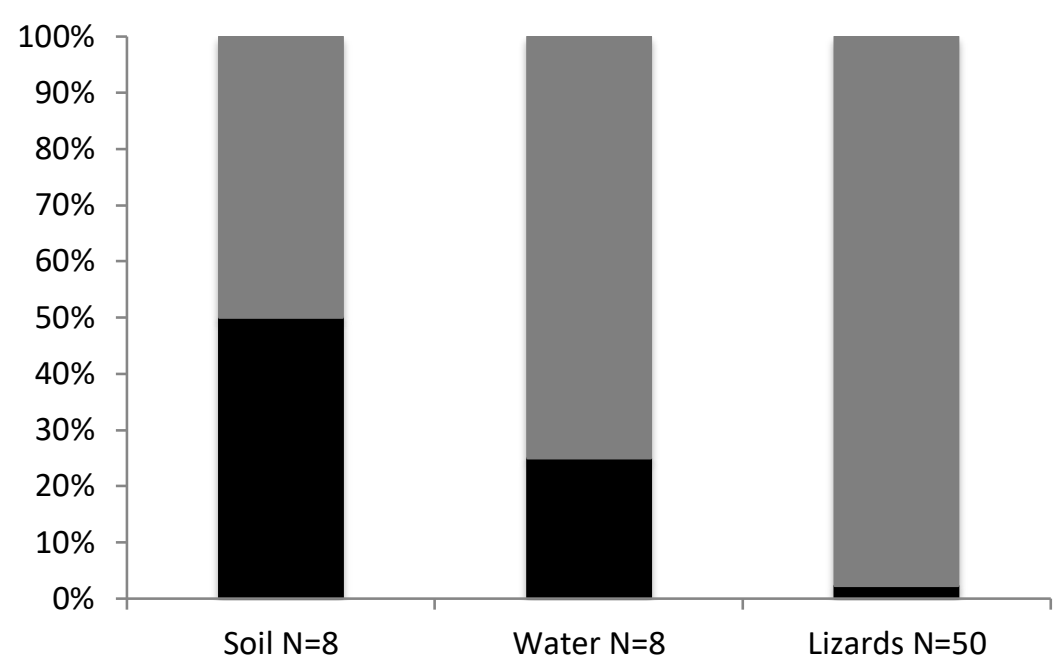

Figure 5: Salmonella positive samples from Southland Island. Percentage of samples positive for Salmonella isolates indicated in black, negative samples in grey. All positive soil samples contained $S$. mississippi, and positive water and lizard samples contained S. houtenae.

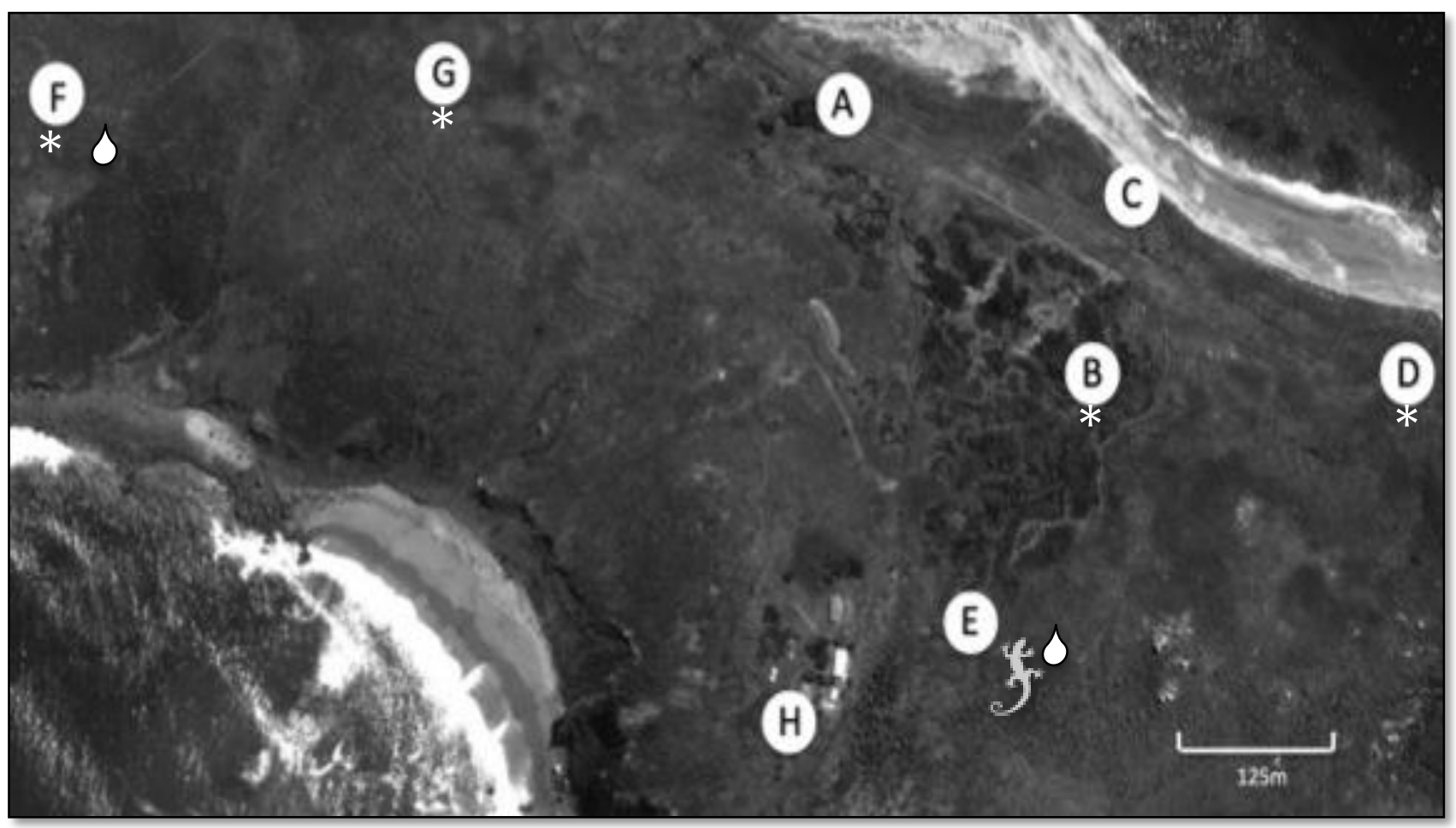

Figure 6: Map of Salmonella positive samples on the private island (Google Maps 2014). Site location not disclosed and partial map presented for security reasons. Letters indicate locations of water sources within each territory in addition to location of water and soil samples taken. An asterisk next to a letter indicates Salmonella was found in the soil in this territory, a water drop indicates Salmonella was found in the water source of the territory and a lizard indicates Salmonella in a lizard sampled in the territory. 


\begin{tabular}{|c|c|c|c|c|}
\hline Site & Substrate & Water Source & Lizard density & Salmonella \\
\hline A & Non-hydric & artificial & medium & none \\
\hline B & Hydric & natural & medium & \\
\hline C & Non-hydric & natural & medium & none \\
\hline D & Non-hydric & artificial & high & \\
\hline $\mathrm{E}$ & Hydric & natural & high & \\
\hline$F$ & Non-hydric & artificial & medium & \\
\hline G & Non-hydric & artificial & low & \\
\hline $\mathrm{H}$ & Non-hydric & artificial & low & none \\
\hline
\end{tabular}

Table 1: Classification of water and soil types sampled, lizard densities and Salmonella found within takahē territories on the private island. An asterisk indicates S. mississippi isolated from soil in the respective territory, a water drop indicates $S$. houtenae isolated from the water and a lizard indicates S. houtenae isolated from a lizard.

\section{Salmonella on Maud Island and Burwood Bush}

The lizard population on Maud Island had a Salmonella prevalence of zero. Additionally, all water and soil samples taken from Maud Island tested negative for Salmonella isolates. Statistical analyses of Maud Island lizard population estimates using WinEpi produced an estimate of maximum possible prevalence of lizard Salmonella carriage of between $6.82 \%$ and $9.5 \%$ at the $95 \%$ confidence level (based on minimum number alive and the highest confidence limit from the weighted means model respectively. Reported in Chapter Two). All environmental samples taken from the Burwood Bush takahē rearing facility tested negative for Salmonella isolates. 


\subsection{Discussion}

\section{Salmonella in lizards}

Salmonella was isolated from the cloacal swab of an adult Oligosoma notosaurus sampled within takahē territory E on the private island. None of the lizards sampled on Maud Island tested positive for Salmonella isolates. A true prevalence of Salmonella carriage of $7-8.2 \%$ was estimated for the lizard population on the private island while a maximum possible prevalence of 5.889.49\% was calculated for the lizard population on Maud Island.

These results correspond to previous findings where Salmonella prevalence of between 0 and $9 \%$ was estimated in wild lizard populations on offshore, New Zealand islands (Middleton et al. 2014; Middleton et al. 2010). However, the intermittent excretion of Salmonella commonly observed in infected reptiles can result in an underestimate of Salmonella prevalence (Scheelings et al. 2011). Intermittent shedding of a bacterium increases the probability of obtaining false negatives and limits the probability of obtaining positive samples from infected animals (Pfleger et al. 2003) suggesting that the Salmonella prevalence in New Zealand lizards may approach the high end of estimates.

In addition, a degree of seasonality to the prevalence of Salmonella in lizards on the private island is likely with greater prevalence occurring in summer. A significant reduction in Salmonella carriage and excretion within free-living reptile populations has been observed in colder months (Kourany \& Telford 1981) and this reduction may be attributed in part to colder temperatures creating sub-optimal growth conditions for bacteria. Enteric bacteria such as Salmonella achieve optimal growth between 35 and $37^{\circ} \mathrm{C}$ (Bronikowski et al. 2001) but the body temperature of ectothermic hosts such as lizards can vary significantly depending on environmental temperatures (Werner \& Whitaker 1978). For example, body temperatures of gravid Oligosoma maccani (McCann's skink) in Otago, New Zealand were found to fluctuate from between $7.2-32.7^{\circ} \mathrm{C}$ depending on environmental temperatures (Hare et al. 2009). 
Previous studies (Baling et al. 2013; Middleton et al. 2014; Middleton et al. 2010) provide a clear indication that endemic lizards have the capacity to harbour Salmonella in New Zealand environments, however each of these studies were carried out at sites off the coast of the North Island of New Zealand or at the northernmost tip of the South Island. The private island is at a significantly more southern latitude than these sites with mean air temperatures as much as $7^{\circ} \mathrm{C}$ cooler in winter months (NIWA National Climate Database). Therefore, temperature-dependent bacteria such as Salmonella may be subject to differential survival in the private island climate.

The highest mean air temperatures on the private island occur from December to March and temperatures during sampling in this study ranged from $11-14^{\circ} \mathrm{C}$ (NIWA Climate Database), indicating that Salmonella prevalence in the lizard population likely reaches a maximum during this time. However, the mean annual air temperature on the Southland Island for 2014 was $7^{\circ} \mathrm{C}$ and fell as low as $1^{\circ} \mathrm{C}$ in winter (NIWA Climate Database). This temperature pattern suggests that lizards on the private island are seldom, if ever able to attain a body temperature high enough for optimal bacterial growth to occur, potentially reducing Salmonella prevalence in the lizard population to an undetectable level in colder weather.

Additionally, as with the Middleton et al (2010) survey, Salmonella was not isolated from the lizard population on Maud Island. Failure to isolate Salmonella serovars from lizards within takahē territories on Maud Island in this study may be indicative of a sample size too small to detect a potentially low Salmonella prevalence. Similarly, the Middleton et al. (2010) study concluded that a larger sample size might be required to identify Salmonella on Maud Island. Furthermore, the microbiological method used to isolate Salmonella is estimated to have a test sensitivity of only 50\% (Middleton et al. 2010; Bager \& Peterson 1991), which suggests that 50\% of individuals carrying Salmonella may not be identified using this method. 
The serovar isolated from the private island skink, Salmonella houtenae (IV) ser. 40: g,t:-, is concurrent with the serovar isolated from two of the eight water sources sampled within takahē territories ( $\mathrm{E}$ and F) in this study in addition to the serovar isolated from a takahē from the same island in 2012 (Grange pers. comm. 2015). Salmonella houtenae is typically a reptile-associated serovar (Schröter et al. 2004; Willis et al. 2002) and so this congruity is suggestive of Salmonella transmission among lizards, water sources and takahē on the island. However, formal identification of Salmonella serovars isolated from takahē, lizards and environmental samples from the Southland Island through whole genome sequencing would confirm sequence similarity of the samples more definitively.

Despite the seemingly low Salmonella prevalence in the lizard population, estimates of lizard population numbers within takahē territories on the private island are indicative of as many as one lizard per square metre (Chapter Two). Fewer than twenty adult takahē reside on the private island at any one time (Phil Marsh pers. comm. 2014) and although Salmonella may not persist in the takahē population alone, a high density of alternative hosts such as lizards may aid in pathogen persistence and interspecific transmission within the system (Begon 2008). In contrast, estimates of the lizard population numbers within takahē territories on Maud Island suggest a much lower density of approximately one lizard per seven-square metres. It is possible that this number is under the required species abundance threshold to enable Salmonella species to persist at a detectable level within the lizard population and hence, the risk of transmission to is takahē negligible.

\section{Salmonella in other sympatric animals}

Each takahē territory on the private island has a central water source in the form of a natural stream or pond as in territories B, C and E or rain fed water feeders as in territories A, D, F, G and $\mathrm{H}$, which are supplemented by island caretakers intermittently (Fig 6). As access to the private island is limited and there are no permanent caretakers in residence, artificial water feeders can evaporate during 
drier months eliminating them as potential water sources. This may put takahē at higher risk of disease transmission due to a higher density of sympatric species utilising common water resources during summer months. Salmonella contamination of water sources has been shown to increase significantly with the number of animals exploiting them. For example, a survey of Salmonella in cattle water troughs found that contamination increased asymptotically as the number of starlings (Sturnus vulgaris) using the troughs increased (Carlson et al. 2011). Subsequent control of the starling population resulted in a substantial decline of Salmonella in the water troughs (Carlson et al. 2011 b). Additionally, high densities of birds at garden feeders have been implicated in outbreaks of Salmonella typhimurium DT40 in the United Kingdom (Carlson et al. 2011). The private island is host to several species of passerines (Passeriformes) including starlings and sparrows (Passer domesticus), both of which have been implicated in Salmonella outbreaks (Carlson et al. 2011; Connolly et al. 2006). It is highly probable that these species also share water sources with takahē, providing another potential source of faecal contamination. Salmonella was isolated from the natural stream in territory $\mathrm{E}$ on the private island. This stream may be one of the only water sources available to takahē during dry months and any animals utilising it may be at higher risk of Salmonella infection. In addition, takahē may be forced to travel through adjacent territories searching for water during drier weather. This behaviour could aid in the intraspecific transmission of Salmonella in the takahē population on private island by increasing contact opportunities between individual birds and contamination of water sources and soil from the faeces of already infected takahē.

The Oligosoma notosaurus that Salmonella was isolated from in this study is from the family Scincidae, which was found to have the highest prevalence of Salmonella serovars in the Middleton 2010 study. In addition, this study found that lizards sampled from coastal zones had a much higher prevalence $\left(\mathrm{P}^{\mathrm{T}}\right.$ $11.5 \%)$ than those caught in bush or open terrain habitats $\left(\mathrm{P}^{\mathrm{T}}\right.$ 2.5-3.3\%) (Middleton 2010). Correspondingly, O. notosaurus is commonly found in coastal habitats (Chapple 2010) suggesting that ecology and habitat choice of lizard populations may play a role in Salmonella prevalence. 
Salmonella carriage in lizards and takahē in coastal environments on the private island could be a result of seabirds and marine mammals living in close proximity (Middleton et al. 2010). A survey of sub Antarctic wildlife found a Salmonella prevalence of $22 \%$ in fur seals (Arctocephalus foresteri) and $7 \%$ in Gentoo penguins (Pygoscelis papua) (Palmgren et al. 2000), and a survey of Antarctic wildlife found Salmonella prevalence as high as 8.9\% in Antarctic seabird species and $5.6 \%$ in Weddel seals (Leptonychotes weddelli) (Vigo et al. 2011). Additionally, large congregations of Herring gulls (Largus argentatus) have been implicated as vectors of Salmonella to sheep and cattle in the United Kingdom (Tizard 2004). Periodic visitation by New Zealand fur seals and seasonal congregations of seabirds are common on the private island and so transmission of Salmonella to takahē and lizards could be occurring through faecal contamination of the environment and food sources by these visiting animals.

Until recently, research has focussed on simple host-parasite systems such as single host-single parasite (Collinge \& Ray 2006; Ostfeld 2010). In reality many host parasite interactions are far more complex (Holt et al. 2003) and the presence of multiple host species within an ecosystem has the potential to greatly increase pathogen persistence (Begon 2008). In order to persist, a pathogen requires a threshold abundance of individual hosts, but if multiple, susceptible hosts are available in a system, then even if the hosts occur under the required abundance threshold the pathogen can persist through interspecific transmission (Begon 2008; Holt et al. 2003). The presence of the same serovar of Salmonella in both takahē and lizards on the private island may be an indication of a complex system involving multiple potential host species including marine mammals, seabirds and passerines, rendering the definitive interpretation of transmission pathways problematic.

Salmonella in soil and water

Salmonella mississippi was isolated from four of the eight soil samples and Salmonella houtenae was isolated from two of the eight water samples taken 
from takahē territories on the Southland island. There was no significant association found between water source type and Salmonella detection in water samples, substrate type and Salmonella detection in soil samples or lizard density and Salmonella detection in environmental (water or soil) samples taken from the private island. However, more intensive sampling from throughout the takahē territories may be necessary to accurately determine environmental predictors of Salmonella occurrence on the private island. Analyses of the correlation between soil type and Salmonella prevalence in broiler chicken farms found that a higher proportion of hydric or "waterlogged" soil increased the probability of Salmonella detection (Volkova et al. 2009). Several sites on the private island are dominated by hydric soils, potentially increasing survival of Salmonella in waterlogged areas.

The presence of Salmonella houtenae in water samples taken from the Southland Island provides an indication that takahē water sources might provide a potential Salmonella reservoir. Fresh water sources have long been implicated in Salmonella transmission and persistence (Baudart et al. 2000). For example, a survey of surface waters in Georgia, United States found that $79 \%$ of all samples contained Salmonella serovars with significantly higher concentrations of Salmonella in addition to significantly higher serovar diversity in summer months (Haley et al. 2009). Additionally, over 40 Salmonella serovars were isolated from natural aquatic systems within a Mediterranean coastal watershed (Baudart et al. 2000). Takahē water troughs on the private island were cleaned and refilled just four days prior to sampling. Salmonella survival is greatly reduced in clean water (Murray 1991) and it is likely that cleaning the water troughs reduced the amount of bacteria present, subsequently reducing the capability of culture methods to detect Salmonella. Artificial water sources on private island are usually cleaned infrequently due to limited access to the island and the subsequent build-up of organic matter may provide a high nutrient content for Salmonella survival and growth in the water troughs under normal conditions (Murray 1991). Cleaning the water troughs may have masked a higher prevalence of Salmonella in the artificial water sources than what was ultimately detected. In addition, time taken to transport soil and water samples 
from the private island, Maud Island and Burwood Bush to the laboratory for culture could have resulted in sample degradation. Transport of soil samples in pre-enrichment media and refrigeration of soil and water samples prior to culture would have helped to negate this effect but it is not known how much, if any, Salmonella was lost during this process.

In contrast to the private island, Salmonella was not isolated from soil or water samples taken from either Maud Island or the Burwood Bush takahē rearing facility. It is particularly interesting that Salmonella was not isolated from environmental samples at Burwood Bush considering is one of the main translocation hubs in the takahē translocation network (Grange et al. 2014) and frequently houses takahē from several populations including Salmonella positive birds from the private island. However, failure to detect Salmonella from samples taken from Maud Island and Burwood Bush are not necessarily indicative of zero Salmonella prevalence at these sites. As with the lizard surveys in this study, prevalence of Salmonella in the soil and water sources at Burwood Bush and Maud Island might occur at such a low frequency that a much larger sample pool than was feasible to process within the context of this study is necessary to detect it. Additionally, Maud Island and the Burwood Bush takahē rearing facility house permanent staff that clean and refill water stations regularly, reducing build-up of organic material and potentially limiting survival of any Salmonella present. Free access to permanent water sources on Maud Island and at Burwood Bush may also reduce the need for takahē to cross into neighbouring territories in search of resources, thus reducing the risk of intraspecific transmission of pathogens. Furthermore, takahē feeding stations on Maud Island and at Burwood Bush are moved frequently, reducing concentration of takahē faecal material in any one area. This may hinder bacterial build up in the soil surrounding feeders, reducing Salmonella persistence in areas of high takahē traffic.

In addition to regular cleaning and movement of takahē feeders and water troughs, both Maud Island and Burwood Bush have strict quarantine procedures in place for human visitors prior to site access; this might prevent transmission 
of pathogens from other animals and sites via contaminated field gear. In contrast, quarantine procedures prior to human access of the private island are limited. Additionally, examination of Salmonella typhimurium in the endemic passerine the hihi (Notiomystis cincta) on Tiritiri Matangi Island in New Zealand using pulsed field gel electrophoresis found that the serovar isolated from infected birds was virtually indistinguishable from that isolated from a human patient in New Zealand (Ewen et al. 2007). Tiritiri Matangi is an isolated island reserve, preventing movement of hihi to other areas and it receives over 30,000 human visitors each year indicating a possibility that Salmonella was introduced to the island via a human carrier. The potential for human introduction of Salmonella to the private island cannot be ruled out.

Salmonella infects a wide range of hosts with many serovars transmissible between species, which indicates a lack of specialised host adaptations (Foltz 1969). This lack of host specialisation may provide Salmonella bacteria with an increased capacity to survive a lifestyle of continued cycling through animal hosts and the environment (Foltz 1969). Salmonella has been reported to survive in soil for up to 332 days (Holley et al. 2006) and its ability to survive in aquatic environments is well documented (Jacobsen \& Bech 2012). Although excretion into the environment exposes Salmonella to survival challenges such as variable temperature, $\mathrm{pH}$ and nutrient availability, Salmonella has evolved to cope with these challenges (Leyer \& Johnson 1992; Matches \& Liston 1968), enabling it to survive independently of animal hosts for extended periods of time thus increasing transmission opportunities via contact with new hosts. This ability of Salmonella to persist in the environment independently of a host greatly increases the potential for persistence of environmental reservoirs of this pathogen. Isolation of Salmonella from both water and soil samples from takahē territories in this study provides an indication that environmental sources play an important role in Salmonella persistence on the Southland Island. 
While it is clear that a Salmonella reservoir or reservoirs exist on the private island, elucidation of transmission pathways is difficult. Lizards on the private island clearly occur at densities high enough to maintain a Salmonella reservoir (See Chapter two) but the presence of multiple other hosts such as passerines, sea birds and marine mammals indicates that several sources might be involved in Salmonella transmission to takahē. Salmonella serovars isolated from lizard, soil and water samples appear to concur with those isolated from takahē indicating a common source of infection and transmission on the private island. However, further investigation such as comparison of whole genome sequences of isolates is needed to confirm the relationship of these Salmonella isolates and clarify Salmonella transmission pathways between takahē, lizards and the environment. 
Chapter Four: Lizards play a role in Salmonella persistence and in transmission to takahé 


\subsection{Introduction}

New Zealand endemic lizard species have been implicated in the transmission of Salmonella to the sympatric takahē population on a private island in the takahē translocation network. Takahē are routinely translocated between several offshore islands for conservation purposes and Salmonella infected takahē from the private island may pose a risk to other takahē in the translocation network. I investigated the ecology of lizard species within takahē territories on the private island in addition to Maud Island, which is residence to another important population of takahē. Species, distribution, density, morphology, habitat preference and Salmonella prevalence of lizards on the private island and Maud Island were investigated to assess the potential risk of Salmonella transmission from lizards to takahē. In addition, I investigated the presence of Salmonella in soil and water within takahē territories on the private island and Maud Island, and in quarantine and brood pens at the Burwood Bush takahē rearing facility. Soil and water samples were cultured for Salmonella in order to identify potential environmental Salmonella reservoirs in takahē territories.

\section{Summary of major findings}

\section{Chapter Two}

To investigate the ecology of lizards within takahe territories on the private island and Maud Island I carried out mark recapture surveys over five days at each island between January and February 2014. I detected three species of skink during the private island survey, Oligosoma notosaurus, 0 . nigriplantare polychroma and 0 . stenotis. Analyses of the lizard population on the private island found that densities are potentially as high as 6,000 lizards per hectare, with 0 . notosaurus accounting for $91.5 \%$ of total captures, 0 . nigriplantare polychroma $7.5 \%$ and 0 . stenotis $1.1 \%$. No geckos were detected on the private island. The finding of 0 . stenotis on the private island is particularly important as this species was previously thought to be restricted to Stewart Island. I detected three species of lizard during the mark recapture survey on Maud Island, $O$. zelandicum, O. nigriplantare polychroma and Woodworthia maculatus. Oligosoma 
zelandicum and W. maculatus represented $47.5 \%$ of total captures each and $O$. nigriplantare polychroma 5\%. Three other lizard species, Oligosoma infrapunctatum, Toropuku stephensi and Mokopirirakau granulatus are present on Maud Island but were not detected during this survey. Estimates of lizard densities within takahē territories were between 466 and 6020 lizards per hectare on the private island and between 118 and 1528 lizards per hectare on Maud Island; the high range of estimates is due to low recapture numbers and the subsequent overestimation of population size by the weighted mean model. These densities provide an indication that lizards could aid in pathogen persistence at these sites and act as a potential disease reservoir for takahē.

\section{Chapter Three}

In order to investigate the role of lizards as Salmonella reservoirs in the takahe translocation network, cloacal swabs were taken from skinks and geckos found within takahē territories on the private island and Maud Island and cultured for Salmonella. Soil and water samples from within takahē territories on the private island and Maud Island were also tested for Salmonella, in addition to soil and water samples taken from quarantine and brooding pens at the Burwood Bush takahē rearing unit. Salmonella houtenae was isolated from one skink and two of eight water samples, and S. mississippi was isolated from four of eight soil samples from the private island. Prevalence of Salmonella in the lizard population of the private island was calculated to be between 2 and $11.8 \%$. No Salmonella was isolated from Maud Island or Burwood Bush but a maximum possible Salmonella prevalence of between 5.9 and $9.5 \%$ was calculated for the lizard population on Maud Island. The serovars isolated from lizards, soil and water on the private island are concurrent with those isolated from takahē there. It appears that the private island maintains a persistent Salmonella reservoir but it remains unclear what its source might be. It is likely that there is a complex Salmonella transmission cycle occurring between takahē, lizards, the environment and other sympatric species such as sea birds and marine mammals on the private island. 


\subsection{Discussion}

The ecology of endemic New Zealand lizards on the private island and Maud Island, and their potential to act as a Salmonella reservoir in the takahē translocation network are inextricably linked. For example, Salmonella carriage of between $2-11.8 \%$ in the lizard population on the private island may sound minimal until combined with lizard density estimates. Even at the lowest density estimate of 466 lizards per hectare, the number of Salmonella infected lizards on the private island could be as many as 55 individuals per hectare, and almost 700 infected individuals per hectare if the highest lizard density is considered. If takahē on the private island are regularly supplementing their diets with lizard prey then it is likely that they will eventually consume Salmonella infected lizards. Salmonella prevalence in New Zealand lizards has been found to be highest in lizards from the family Scincidae (Middleton et al. 2010), the most commonly occurring lizard family on both the private island and Maud Island.

Additionally, habitat preference of lizards within the takahē translocation network might affect Salmonella prevalence rates in the lizard population. Lizards with a preference for open habitats might achieve greater body temperatures than those found in shaded habitats, thus providing more optimal temperatures for any concomitant Salmonella species to proliferate (Kourany \& Telford 1981) and lizard populations in coastal environments might harbour a higher prevalence of Salmonella carriage than lizards found inland (Middleton 2010) due to exposure to sea birds and marine mammals which are known Salmonella carriers (Palmgren et al. 2000; Tizard 2004). Furthermore, evidence of lizard movement outside of the expected four-metre home range on the private island might provide insight into how Salmonella is transmitted to other lizards, the environment or takahē in neighbouring territories. The area of takahē territories is often restricted by the limited habitat available to them on islands were they reside (Baber \& Craig 2003). As a result, takahē territories are often overlapping, increasing the risk of lizards and takahē spilling over into neighbouring territories and increasing pathogen transmission. 
Alternatively, Salmonella infection in lizards and takahē on the private island could originate in other sympatric species. Passerines are ubiquitous on the private island and sea birds and marine mammals are frequent visitors. Takahē and lizards may have direct or indirect contact with sympatric species, thus providing multiple opportunities for pathogen transmission.

\section{Conservation Implications}

This study represents the first survey of lizard populations carried out on the private island, and one of few undertaken on Maud Island, highlighting the apparent lack of knowledge regarding lizard ecology in New Zealand. The high density of lizards estimated in this study provide an indication that lizards might play a crucial role in both island's ecosystem functioning. Without fundamental ecological knowledge about New Zealand lizard ecology and their role in the ecological community, it is not known how management actions might affect lizard populations, or what effect changes in lizard populations might have on sympatric flora and fauna. For example, re-vegetation efforts on both the private island and Maud Island could cause range constrictions and reduced carrying capacity of lizard populations with a preference for more open habitat. The resulting decrease in lizard density could reduce or change patterns of pollination and seed dispersal (Traveset \& Riera 2005) and diminish an important source of prey for sympatric species (Fox 1977; Van Winkle \& Ji 2012). The potential effects of re-vegetation actions on lizard fauna, and carry on effects to sympatric plant and animal species should be considered during vegetation restoration planning stages.

Additionally, information on the species distribution, densities and morphology of lizard communities on Maud Island is severely lacking. Without this basic knowledge, the effects of the recent mouse incursion on the lizard population on Maud Island cannot be fully understood. A group of Toropuku stephensi were removed from Maud Island to protect them from the impact of mouse invasion (Chris Birmingham pers. comm. 2014). However, without an existing estimate of the T. stephensi population size on Maud Island, the benefit of this management 
action cannot be fully assessed. Regular monitoring of the lizard population using a variety of trapping methods to target all species should be undertaken on Maud Island in order to better inform management decisions regarding the lizard fauna. In addition to Maud Island, the discovery of Oligosoma stenotis on the private island outside of its previously known range further emphasises the dearth of knowledge regarding New Zealand endemic lizard species. Development of a comprehensive New Zealand lizard species inventory including lizard distributions is essential for informing management of species. Without knowledge of where threatened and rare lizard species occur, management decisions regarding their conservation are likely to be ineffective (Hitchmough et al. 2013.

The high densities of lizards on both the private island and Maud Island indicate that lizards could play a vital role in pathogen persistence and transmission in the takahē translocation network. Pathogens such as Salmonella could persist in the lizard population when other hosts such as takahē are not abundant or maintain a pathogen during seasons where seabird colonies or marine mammals are absent. Furthermore, understanding the seasonal patterns associated with Salmonella prevalence in lizards and the environment within takahē territories on the private island may be crucial in mitigating disease transmission risks to takahē and in timing takahē translocations to and from the island.

\section{Future Directions}

\section{Lizards}

In order to better understand lizard ecology on the private island and Maud Island a more comprehensive survey of species presence and their distribution is necessary. Trapping using multiple methods may be needed to detect all lizard species present, particularly geckos that can escape the pitfall traps used in this study. Additionally, further analyses of species-specific habitat use will inform pitfall placements to better detect lizard species and improve re-vegetation planning in terms of meeting habitat requirements for all lizard species. Long 
term, annual monitoring of lizards using mark recapture methods is needed to assess how re-vegetation on the private island and reforestation and pest control on Maud Island are affecting the distribution and abundance of lizard species residing at these sites.

\section{Salmonella}

While it is clear that a Salmonella reservoir or reservoirs exist on the private island, elucidation of transmission pathways could not be determined in this study and further research is needed to address this problem. The Salmonella serovars isolated from lizard, soil and water samples appear to concur with those isolated from takahē on the private island but more thorough examination of isolates is required to confirm this. Whole genome sequencing of Salmonella isolated from lizards, the environment and takahe from the private island are required to assess the degree of relatedness between isolates. Although serotyping used in this study is the accepted method of Salmonella serotype identification, it is limited in that it can't identify evolutionary relationships of strains within the same or between different serotypes (Selander et al. 1990). Multi-host pathogens such as Salmonella often display a pattern of rapid host adaptations resulting in what are sometimes major genetic changes, confounding elucidation of evolutionary relationships (Beltran et al. 1988). Analysis of whole genome sequences has emerged as a tool to measure relatedness between different strains of the same Salmonella serotype (Sukhnanand et al. 2005). Using whole genome sequencing to understand how related Salmonella isolates from lizards and the environment in this study are to Salmonella isolated from takahē could provide clearer insight into Salmonella transmission pathways on the private island. Additionally, methods for detection of Salmonella remain imperfect and development of alternative, more effective methods is necessary to advance Salmonella detection. The culture method used to detect Salmonella in this study has a sensitivity of 50\% (Bager \& Peterson 1990), indicating that as many as $50 \%$ of Salmonella positive samples remain undetected. 
In addition, further investigation of Salmonella prevalence and serovars present in takahē, lizards, other sympatric species and soil and water is required to determine potential Salmonella reservoirs and aid in the understanding of disease transmission on the private island. Surveying takahē and sympatric species on the private island for Salmonella carriage over different seasons may provide an indication of when Salmonella prevalence in the wildlife community is highest, and how it cycles through individuals and the community, therefore informing decisions on timing of takahē translocations to and from the island. In addition, further sampling of lizard populations and the environment is needed to understand the potential prevalence of Salmonella on Maud Island and Burwood Bush and associated risks of Salmonella transmission to and from takahē at these sites.

Although it is difficult to isolate the sources of Salmonella infection, implementation of management actions might mitigate Salmonella transmission in takahē from the private island and throughout the wider takahē translocation network. I therefore recommend the following actions, although implementation is entirely subject to resources available to the Department of Conservation takahē management team and caretakers on the private island.

1. More frequent cleaning and filling of artificial water sources on the private island may reduce build up and survival of Salmonella whilst reducing the need for takahē to cross territories in search of water. This may limit ingestion of Salmonella infected water by takahē and sympatric species and reduce transmission of Salmonella among takahē territories.

2. Frequent movement of takahē feeding hoppers to prevent high concentrations of faecal material from building up, limiting the potential for Salmonella reservoirs in the soil.

3. Quarantine and treat Salmonella infected takahē on the private island prior to moving them through the translocation network to prevent Salmonella transmission to other birds and sites. Alternatively, develop a 
quarantine unit on the mainland separate to the Burwood Bush facility specifically for private island takahē.

This study provides vital insight into the transmission of Salmonella and its maintenance in the takahē translocation network. Findings reported here will inform future decisions regarding takahē translocations and disease screening, and ultimately contribute to the conservation of this threatened species. Furthermore, this study supplies fundamental ecological knowledge about the lizard fauna on the private island and Maud Island and will aid in the preservation and management of New Zealand endemic lizard species. 


\section{References}

Acheson, D., \& Hohmann, E. L. (2001). Nontyphoidal salmonellosis. Clinical Infectious Diseases, 32(2), 263-269.

Alexander, K. A., \& Appel, M. J. (1994). African wild dogs (Lycaon pictus) endangered by a canine distemper epizootic among domestic dogs near the Masai Mara National Reserve, Kenya. Journal of wildlife diseases, 30(4), 481-485.

Alley, M. R., Connolly, J. H., Fenwick, S. G., Mackereth, G. F., Leyland, M. J., Rogers, L. E. \& Reed, C. E. M. (2002). An epidemic of salmonellosis caused by Salmonella Typhimurium DT160 in wild birds and humans in New Zealand.New Zealand Veterinary Journal, 50(5), 170-176.

Anderson, R. M., May, R. M., Joysey, K., Mollison, D., Conway, G. R., Cartwell, R. \& Dixon, B. (1986). The invasion, persistence and spread of infectious diseases within animal and plant communities [and discussion]. Philosophical Transactions of the Royal Society B: Biological Sciences, 314(1167), 533-570.

Bager, F., \& Petersen, J. (1990). Sensitivity and specificity of different methods for the isolation of Salmonella from pigs. Acta Veterinaria Scandinavica, 32(4), 473-481.

Baling, M., Ji, W., Gartrell, B., \& Brunton, D. H. (2013). Detection of Salmonella during the translocation of two endemic New Zealand lizard species within the Hauraki Gulf. New Zealand Journal of Zoology, 40(3), 249-254.

Baudart, J., Lemarchand, K., Brisabois, A., \& Lebaron, P. (2000). Diversity of Salmonella strains isolated from the aquatic environment as determined by serotyping and amplification of the ribosomal DNA spacer regions. Applied and Environmental Microbiology, 66(4), 1544-1552.

Begon, M., (1979). Investigating animal abundance: capture-recapture for biologists. Edward Arnold (Publishers) Ltd..

Begon, M. (2008). Effects of host diversity on disease dynamics. Infectious Disease Ecology: Effects of Ecosystems on Disease and of Disease on Ecosystems, 12-29. 
Beltran, P., Musser, J. M., Helmuth, R., Farmer, J. J., Frerichs, W. M., Wachsmuth, I. K. \& Cravioto, A. (1988). Toward a population genetic analysis of Salmonella: genetic diversity and relationships among strains of serotypes S. choleraesuis, S. derby, S. dublin, S. enteritidis, S. heidelberg, S. infantis, S. newport, and S. typhimurium. Proceedings of the National Academy of Sciences, 85(20), 77537757.

Bjergbaek, L. A., \& Roslev, P. (2005). Formation of nonculturable Escherichia coli in drinking water. Journal of applied microbiology, 99(5), 1090-1098.

Brittingham, M. C., \& Temple, S. A. (1986). A survey of avian mortality at winter feeders. Wildlife Society Bulletin, 445-450.

Bronikowski, A. M., Bennett, A. F., \& Lenski, R. E. (2001). Evolutionary adaptation to temperature. VIII. Effects of temperature on growth rate in natural isolates of Escherichia coli and Salmonella enterica from different thermal environments. Evolution, 55(1), 33-40.

aCarlson, J. C., Engeman, R. M., Hyatt, D. R., Gilliland, R. L., DeLiberto, T. J., Clark, L. \& Linz, G. M. (2011). Efficacy of European starling control to reduce Salmonella enterica contamination in a concentrated animal feeding operation in the Texas panhandle. BMC veterinary research, $7(1), 9$.

Carlson, J. C., Franklin, A. B., Hyatt, D. R., Pettit, S. E., \& Linz, G. M. (2011). The role of starlings in the spread of Salmonella within concentrated animal feeding operations. Journal of applied ecology, 48(2), 479-486.

Chapple, D.G. 2010. Oligosoma notosaurus. The IUCN Red List of Threatened Species. Version 2014.3. www.iucnredlist.org. Downloaded on 10 January 2015.

Collinge, S. K., \& Ray, C. (2006). Disease ecology: community structure and pathogen dynamics. Oxford University Press.

Connolly, J. H., Alley, M. R., Dutton, G. J., \& Rogers, L. E. (2006). Infectivity and persistence of an outbreak strain of Salmonella enterica serotype Typhimurium DT160 for house sparrows (Passer domesticus) in New Zealand.New Zealand veterinary journal, 54(6), 329-332.

Cunningham, A. A. (1996). Disease risks of wildlife translocations. Conservation Biology, 10(2), 349-353.

Daszak, P., Cunningham, A. A., \& Hyatt, A. D. (2000). Emerging infectious diseases of wildlife--threats to biodiversity and human health. Science, 287(5452), 443-449. 
De Hamel, F. A., \& McInnes, H. M. (1971). Lizards as vectors of human salmonellosis. Journal of Hygiene, 69(02), 247-253.

Department of Conservation parks and recreation (2015). Available from: http://www.doc.govt.nz/parks-and-recreation/places-to go/malborough/places/maud-island/. (8 February 2015)

East, K. T., East, M. R., \& Daugherty, C. H. (1995). Ecological restoration and habitat relationships of reptiles on Stephens Island, New Zealand. New Zealand Journal of Zoology, 22(3), 249-261.

Efford, M. (1992). Comment-Revised estimates of the bias in the minimum number alive estimator. Canadian Journal of Zoology, 70(3), 628-631.

ESR Public Health Surveillance 2010 https://surv.esr.cri.nz/PDF_surveillance/ERL/NonHumSalm/2010/NonHumSal $\mathrm{m} 2010$.

Ewen, J. G., Armstrong, D. P., Empson, R., Jack, S., Makan, T., McInnes, K., \& Alley, M. (2012). Parasite management in translocations: lessons from a threatened New Zealand bird. Oryx, 46(03), 446-456.

Ewen, J. G., Thorogood, R., Nicol, C., Armstrong, D. P., \& Alley, M. (2007). Salmonella typhimurium in hihi, New Zealand. Emerging infectious diseases,13(5), 788.

Flannagan, H. J. (2000). Conservation biology of the goldstripe gecko (Hoplodactylus chrysosireticus) and interactions with Duvaucel's gecko (Hoplodactylus duvaucelii) on Mana Island, Cook Strait, New Zealand: a thesis presented in partial fulfilment for the degree of Master of Science in Ecology at Massey University (Doctoral dissertation).

Flint, K. P. (1987). The long-term survival of Escherichia coli in river water.Journal of Applied Bacteriology, 63(3), 261-270.

Foltz, V. D. (1969). Salmonella ecology. Journal of the American Oil Chemists' Society, 46(5), 222-224.

Fox, N. C. (1977). The biology of the New Zealand Falcon (Falco Novaeseelandlae Gmelin 1788).

Freeman, A. B. (1997). Comparative ecology of two Oligosoma skinks in coastal Canterbury: a contrast with Central Otago. New Zealand Journal of Ecology, 21(2), 153-160. 
Gartrell, B. D., Alley, M. R., Mack, H., Donald, J., McInnes, K., \& Jansen, P. (2005). Erysipelas in the critically endangered kakapo (Strigops habroptilus).Avian Pathology, 34(5), 383-387.

Gartrell, B. D., Youl, J. M., King, C. M., Bolotovski, I., McDonald, W. L., \& Nelson, N. J. (2007). Failure to detect Salmonella species in a population of wild tuatara (Sphenodon punctatus). New Zealand veterinary journal, 55(3), 134-136.

Gill, B. J. (1976). Aspects of the ecology, morphology, and taxonomy of two skinks (Reptilia: Lacertilia) in the coastal Manawatu area of New Zealand. New Zealand journal of zoology, 3(2), 141-157.

Giovannini, S., Pewsner, M., Hüssy, D., Hächler, H., Degiorgis, M. P. R., von Hirschheydt, J., \& Origgi, F. C. (2012). Epidemic of Salmonellosis in Passerine Birds in Switzerland With Spillover to Domestic Cats. Veterinary Pathology Online.

Gopee, N. V., Adesiyun, A. A., \& Caesar, K. (2000). Retrospective and longitudinal study of salmonellosis in captive wildlife in Trinidad. Journal of Wildlife diseases, 36(2), 284-293.

Gopinath, S., Carden, S., \& Monack, D. (2012). Shedding light on Salmonella carriers. Trends in microbiology, 20(7), 320-327.

Grange, Z. L., Van Andel, M., French, N. P., \& Gartrell, B. D. (2014). Network Analysis of Translocated Takahe Populations to Identify Disease Surveillance Targets. Conservation Biology, 28(2), 518-528.

Griffith, B., Scott, J. M., Carpenter, J. W., \& Reed, C. (1993). Animal translocations and potential disease transmission. Journal of Zoo and Wildlife Medicine, 231-236.

Griffith, B., Scott, J. M., Carpenter, J. W., \& Reed, C. (1989). Translocation as a species conservation tool: status and strategy. Science(Washington),245(4917), 477-480.

Hall, A. J., \& Saito, E. K. (2008). Avian wildlife mortality events due to salmonellosis in the United States, 1985-2004. Journal of wildlife diseases,44(3), 585-593.

Haley, B. J., Cole, D. J., \& Lipp, E. K. (2009). Distribution, diversity, and seasonality of waterborne salmonellae in a rural watershed. Applied and environmental microbiology, 75(5), 1248-1255.

Hare, K.M., (2012). Herpetofauna: indices of abundance Version 1.0. DOCDM-493179, Department of Conservation Inventory and monitoring toolbox: herpetofauna. 
Hare, K. M., Hoare, J. M., \& Hitchmough, R. A. (2007). Investigating natural population dynamics of Naultinus manukanus to inform conservation management of New Zealand's cryptic diurnal geckos. Journal of Herpetology,41(1), 81-93.

Hare, J. R., Holmes, K. M., Wilson, J. L., \& Cree, A. (2009). Modelling exposure to selected temperature during pregnancy: the limitations of squamate viviparity in a coolclimate environment. Biological journal of the Linnean Society, 96(3), 541-552.

Hess, G. (1996). Disease in metapopulation models: implications for conservation. Ecology, 1617-1632.

Hitchmough, R., Anderson, P., Barr, B., Monks, J., Lettink, M., Reardon, J., \& Whitaker, T. (2013). Conservation status of New Zealand reptiles, 2012. New Zealand Threat Classification Series, 2, 16.

Hoare, J. M., Pledger, S., Nelson, N. J., \& Daugherty, C. H. (2007). Avoiding aliens: behavioural plasticity in habitat use enables large, nocturnal geckos to survive Pacific rat invasions. Biological Conservation, 136(4), 510-519.

Holt, R. D., Dobson, A. P., Begon, M., Bowers, R. G., \& Schauber, E. M. (2003). Parasite establishment in host communities. Ecology Letters, 6(9), 837-842.

Ignacio de Blas (2010). Win Epi. Facultad de Veterinaria, Universidad de Zaragoza.

Holt, R. D., Dobson, A. P., Collinge, S. K., \& Ray, C. (2006). Extending the principles of community ecology to address the epidemiology of host-pathogen systems. Disease ecology: community structure and pathogen dynamics, 6-27.

Holley, R. A., Arrus, K. M., Ominski, K. H., Tenuta, M., \& Blank, G. (2006). Survival in Manure-Treated Soils during Simulated Seasonal Temperature Exposure. Journal of environmental quality, 35(4), 1170-1180.

Island, T. M. L. (2010). Translocation of moko Skink (Oligosoma moco) from Lady Alice, Whatupuke and Coppermine Islands to Matakohe-Limestone Island (November/December 2009).

Jacobsen, C. S., \& Bech, T. B. (2012). Soil survival of Salmonella and transfer to freshwater and fresh produce. Food Research International, 45(2), 557-566.

Jamieson IG, Wallis GP, and Briskie JV (2006). Inbreeding and endangered species management: is New Zealand out of step with the rest of the world? Conservation Biology 20:38-47. 
Jenkins, R. E. (1988). Information management for the conservation of biodiversity. Biodiversity, 231-39.

Johnson-Delaney, C. A., \& Mader, D. R. (1996). Reptile zoonoses and threats to public health. Reptile medicine and surgery., 20-33.

Johnson, P. T., Stanton, D. E., Preu, E. R., Forshay, K. J., \& Carpenter, S. R. (2006). Dining on disease: how interactions between infection and environment affect predation risk. Ecology, 87(8), 1973-1980.

Kennedy, S., Kuiken, T., Jepson, P. D., Deaville, R., Forsyth, M., Barrett, T.\& Wilson, S. (2000). Mass die-Off of Caspian seals caused by canine distemper virus. Emerging infectious diseases, 6(6), 637.

Kingsley, R. A., van Amsterdam, K., Kramer, N., \& Bäumler, A. J. (2000). The shdA Gene Is Restricted to Serotypes of Salmonella enterica Subspecies I and Contributes to Efficient and Prolonged Fecal Shedding. Infection and immunity,68(5), 27202727.

Kourany, M., \& Telford, S. R. (1981). Lizards in the ecology of salmonellosis in Panama. Applied and environmental microbiology, 41(5), 1248-1253.

Lafferty, K. D., \& Gerber, L. R. (2002). Good medicine for conservation biology: the intersection of epidemiology and conservation theory. Conservation Biology,16(3), 593-604.

Lancia, R. A., Nichols, J. D., \& Pollock, K. H. (1994). Estimating the number of animals in wildlife populations. Research and management techniques for wildlife and habitats. The Wildlife Society, Bethesda, Maryland, USA, 215-253.

Lawson, B., Howard, T., Kirkwood, J. K., Macgregor, S. K., Perkins, M., Robinson, R. A., ... \& Cunningham, A. A. (2010). Epidemiology of salmonellosis in garden birds in England and Wales, 1993 to 2003. Ecohealth, 7(3), 294-306.

Lettink, M., \& Cree, A. (2007). Relative use of three types of artificial retreats by terrestrial lizards in grazed coastal shrubland, New Zealand. Applied Herpetology, 4(3), 227-243.

Leyer, G. J., \& Johnson, E. A. (1992). Acid adaptation promotes survival of Salmonella spp. in cheese. Applied and Environmental Microbiology, 58(6), 2075-2080.

Matches, J. R., \& Liston, J. (1968). Low temperature growth of Salmonella.Journal of Food Science, 33(6), 641-645. 
McCallum, H. (2012). Disease and the dynamics of extinction. Philosophical Transactions of the Royal Society B: Biological Sciences, 367(1604), 2828-2839

McCallum, J. (1986). Evidence of predation by kiore upon lizards from the Mokohinau Islands. New Zealand journal of ecology, 9, 83-88.

McClelland, M., Sanderson, K. E., Spieth, J., Clifton, S. W., Latreille, P., Courtney, L., \& Wilson, R. K. (2001). Complete genome sequence of Salmonella enterica serovar Typhimurium LT2. Nature, 413(6858), 852-856.

McInnes, H. M. (1971). Salmonella saintpaul infection of sheep with lizards as possible reservoirs. New Zeal Vet J.

McInnes, K., Cromarty, P., \& Ombler, J. (2004). Standard Operating Procedure for the Health Management of Terrestrial Vertebrate Species Protected under the Wildlife Act. Wildlife Health SOP) Document Number WGNCR-49724. Department of Conservation, Wellington, New Zealand.

Mermin, J., Hutwagner, L., Vugia, D., Shallow, S., Daily, P., Bender, J. \& Angulo, F. J. (2004). Reptiles, amphibians, and human Salmonella infection: a population-based, casecontrol study. Clinical Infectious Diseases,38, S253-S261.

Middleton, D. M., La Flamme, A. C., Gartrell, B. D., \& Nelson, N. J. (2014). Reptile reservoirs and seasonal variation in the environmental presence of salmonella in an island ecosystem, Stephens island, New Zealand. Journal of wildlife diseases, 50(3), 655-659.

Middleton, D. M., Minot, E. O., \& Gartrell, B. D. (2010). Salmonella enterica serovars in lizards of New Zealand's offshore islands. New Zealand Journal of Ecology, 34(2), 247.

Mills, J. A., Lee, W. G., Mark, A. F., \& Lavers, R. B. (1980). Winter use by takahe (Notornis mantelli) of the Summer-Green Fern (Hypolepsis millefolium) in relation to Its annual cycle of carbohydrates and minerals. New Zealand Journal of Ecology, 3, 131-137.

Murray, C. J. (1991). Salmonellae in the environment. Revue scientifique et technique (International Office of Epizootics), 10(3), 765.

NIWA National Climate Database. http://cliflo.niwa.co.nz/pls/niwp/wstn.update_stn_query (2014). 
Neilson, K., Curran, J. M., Towns, D. R., \& Jamieson, H. (2006). Habitat use by chevron skinks (Oligosoma homalonotum)(Sauria: Scincidae) on Great Barrier Island, New Zealand. New Zealand Journal of Ecology, 30(3), 345-356.

Newman, D. G. (1994). Effects of a mouse, Mus musculus, eradication programme and habitat change on lizard populations of Mana Island, New Zealand, with special reference to McGregor's skink, Cyclodina macgregori.New Zealand journal of zoology, 21(4), 443-456.

Ngai Tahu Claims Settlement Act 1998, Deed of Settlement Section 13. Available at: http://www.legislation.govt.nz/act/public/1998/0097/latest/DLM429090.html . (January 2014).

Onderka, D. K., \& Finlayson, M. C. (1985). Salmonellae and salmonellosis in captive reptiles. Canadian journal of comparative medicine, 49(3), 268.

Olesen, J. M., \& Valido, A. (2003). Lizards as pollinators and seed dispersers: an island phenomenon. Trends in Ecology \& Evolution, 18(4), 177-181.

Ostfeld, R. S., Keesing, F., \& Eviner, V. T. (Eds.). (2010). Infectious disease ecology: effects of ecosystems on disease and of disease on ecosystems. Princeton University Press.

Palmgren, H., McCafferty, D., Aspan, A., Broman, T., Sellin, M., Wollin, R., ... \& Olsen, B. (2000). Salmonella in sub-Antarctica: low heterogeneity in Salmonella serotypes in South Georgian seals and birds. Epidemiology and infection,125(02), 257-262.

Patterson, G. B. (1992). The ecology of a New Zealand grassland lizard guild. Journal of the Royal Society of New Zealand, 22(2), 91-106.

Patterson, G. B., \& Daugherty, C. H. (1990). Four new species and one new subspecies of skinks, genus Leiolopisma (Reptilia: Lacertilia: Scincidae) from New Zealand. Journal of the Royal Society of New Zealand, 20(1), 65-84.

Patterson, G. B., \& Daugherty, C. H. (1994). Leiolopisma stenotis, n. sp.,(Reptilia: Lacertilia: Scincidae) from Stewart Island, New Zealand. Journal of the Royal Society of New Zealand, 24(1), 125-132.

Pfleger, S., Benyr, G., Sommer, R., \& Hassl, A. (2003). Pattern of Salmonella excretion in amphibians and reptiles in a vivarium. International journal of hygiene and environmental health, 206(1), 53-59. 
Pocock, M. J. O., Searle, J. B., Betts, W. B., \& White, P. C. L. (2001). Patterns of infection by Salmonella and Yersinia spp. in commensal house mouse (Mus musculus domesticus) populations. Journal of applied microbiology, 90(5), 755-760.

Reardon, J. T., Whitmore, N., Holmes, K. M., Judd, L. M., Hutcheon, A. D., Norbury, G., \& Mackenzie, D. I. (2012). Predator control allows critically endangered lizards to recover on mainland New Zealand. New Zealand Journal of Ecology, 36(2), 141.

Robinson, R. A., Lawson, B., Toms, M. P., Peck, K. M., Kirkwood, J. K., Chantrey, J., ... \& Cunningham, A. A. (2010). Emerging infectious disease leads to rapid population declines of common British birds. PLoS one, 5(8), e12215.

Roff, D. A. (1973). An examination of some statistical tests used in the analysis of markrecapture data. Oecologia, 12(1), 35-54.

Rocke, T. E., \& Yuill, T. M. (1987). Microbial infections in a declining wild turkey population in Texas. The Journal of wildlife management, 778-782.

Scheelings, T. F., Lightfoot, D., \& Holz, P. (2011). Prevalence of Salmonella in Australian reptiles. Journal of wildlife diseases, 47(1), 1-11.

Schröter, M., Roggentin, P., Hofmann, J., Speicher, A., Laufs, R., \& Mack, D. (2004). Pet snakes as a reservoir for Salmonella enterica subsp. diarizonae (Serogroup IIIb): a prospective study. Applied and environmental microbiology,70(1), 613-615.

Schwarzkopf, L., \& Shine, R. (1991). Thermal biology of reproduction in viviparous skinks, Eulamprus tympanum: why do gravid females bask more?. Oecologia, 88(4), 562-569.

Selander, R. K., Beltran, P., Smith, N. H., Helmuth, R., Rubin, F. A., Kopecko, D. J. \& Musser, J. M. (1990). Evolutionary genetic relationships of clones of Salmonella serovars that cause human typhoid and other enteric fevers.Infection and immunity, 58(7), 2262-2275.

Sherley, G., Stringer, I. A. N., \& Parrish, G. R. (2010). Summary of Native Bat, Reptile, Amphibian, and Terrestrial Invertebrate Translocations in New Zealand. Pub. Team, Department of Conservation.

Skerratt, L. F., Berger, L., Speare, R., Cashins, S., McDonald, K. R., Phillott, A. D. \& Kenyon, N. (2007). Spread of chytridiomycosis has caused the rapid global decline and extinction of frogs. EcoHealth, 4(2), 125-134. 
Smith, K. F., Acevedo-Whitehouse, K., \& Pedersen, A. B. (2009). The role of infectious diseases in biological conservation. Animal Conservation, 12(1), 1-12.

Smith, M. J., White, A., Sherratt, J. A., Telfer, S., Begon, M., \& Lambin, X. (2008). Disease effects on reproduction can cause population cycles in seasonal environments. Journal of Animal Ecology, 77(2), 378-389.

Sukhnanand, S., Alcaine, S., Warnick, L. D., Su, W. L., Hof, J., Craver, M. P. J. \& Wiedmann, M. (2005). DNA sequence-based subtyping and evolutionary analysis of selected Salmonella enterica serotypes. Journal of clinical microbiology, 43(8), 3688-3698.

Teixeira, C. P., De Azevedo, C. S., Mendl, M., Cipreste, C. F., \& Young, R. J. (2007). Revisiting translocation and reintroduction programmes: the importance of considering stress. Animal Behaviour, 73(1), 1-13.

The New Zealand Herpetological Society. http://www.reptiles.org.nz/introduction.html (2014).

Thrusfield, M. (2005). Veterinary epidemiology. Blackwell Science, Oxford, United Kingdom.

Tingley, R., Hitchmough, R. A., \& Chapple, D. G. (2013). Life-history traits and extrinsic threats determine extinction risk in New Zealand lizards. Biological Conservation, 165, 62-68.

Tizard, I. (2004, April). Salmonellosis in wild birds. In Seminars in avian and exotic pet medicine 13(2) 50-66.

Tocher, M. D. (2009). Life history traits contribute to decline of critically endangered lizards at Macraes Flat, Otago. New Zealand Journal of Ecology, 33(2), 125.

Towns, D. R. (1991). Response of lizard assemblages in the Mercury Islands, New Zealand, to removal of an introduced rodent: the kiore (Rattus exulans). Journal of the Royal Society of New Zealand, 21(2), 119-136.

Towns, D. R. (1996). Changes in Habitat Use by Lizards on a New Zealand Island Following Removal of the Introduced Pacific Rat'Rattus exulans'. Pacific conservation biology, 2(3), 286.

Towns, D. R., Atkinson, I. A. E., \& Daugherty, C. H. (1990). The potential for ecological restoration in the Mercury Islands. Ecological restoration of New Zealand islands. Conservation sciences publication, (2), 91-108. 
Towns, D. R., \& Daugherty, C. H. (1994). Patterns of range contractions and extinctions in the New Zealand herpetofauna following human colonisation. New Zealand journal of zoology, 21(4), 325-339.

Towns, D. R., Daugherty, C. H., \& Cree, A. (2001). Raising the prospects for a forgotten fauna: a review of 10 years of conservation effort for New Zealand reptiles. Biological conservation, 99(1), 3-16.

Towns, D. R., \& Elliott, G. P. (1996). Effects of habitat structure on distribution and abundance of lizards at Pukerua Bay, Wellington, New Zealand. New Zealand journal of ecology, 20(2), 191-206.

Towns, D. R. (1996). Changes in Habitat Use by Lizards on a New Zealand Island Following Removal of the Introduced Pacific Rat'Rattus exulans'. Pacific conservation biology, 2(3), 286.

Towns, D. R., \& Ferreira, S. M. (2001). Conservation of New Zealand lizards (Lacertilia: Scincidae) by translocation of small populations. Biological conservation, 98(2), 211-222.

Traveset, A., \& Riera, N. (2005). Disruption of a plant-lizard seed dispersal system and its ecological effects on a threatened endemic plant in the Balearic Islands. Conservation Biology, 19(2), 421-431.

van Riper III, C., van Riper, S. G., \& Hansen, W. R. (2002). Epizootiology and effect of avian pox on Hawaiian forest birds. The Auk, 119(4), 929-942.

Van Winkel, D., \& Ji, W. (2012). Evidence of lizard predation by New Zealand kingfishers (Todiramphus sanctus vagans) and potential implications for threatened species translocations. New Zealand Journal of Zoology, 39(3), 201-208.

Viggers, K. L., Lindenmayer, D. B., \& Spratt, D. M. (1993). The importance of disease in reintroduction programmes. Wildlife Research, 20(5), 687-698.

Vigo, G. B., Leotta, G. A., Caffer, M. I., Salve, A., Binsztein, N., \& Pichel, M. (2011). Isolation and characterization of Salmonella enterica from Antarctic wildlife. Polar biology, 34(5), 675-681.

Volkova, V. V., Bailey, R. H., \& Wills, R. W. (2009). Salmonella in broiler litter and properties of soil at farm location. PLoS One, 4(7), e6403.

Warwick, C., Lambiris, A. J., Westwood, D., \& Steedman, C. (2001). Reptile-related salmonellosis. Journal of the Royal Society of Medicine, 94(3), 124. 
Werner, Y. L., \& Whitaker, A. H. (1978). Observations and comments on the body temperatures of some New Zealand reptiles. New Zealand Journal of Zoology, 5(2), 375-393.

Whitaker, A. H. (1991). Research on the Striped Gecko,(Hoplodactylus Stephensi), on Maud Island, Pelorus Sound, Marlborough 6-12 March 1991. Department of Conservation.

Whitaker, A. H., Hitchmough, R. A., \& Chappell, R. (1999). A striped gecko (Hoplodactylus stephensi) at Coromandel. Department of Conservation.

Whitaker, A. H., \& Lyall, J. (2004). Conservation of lizards in West Coast/Tai Poutini Conservancy (p. 93). Wellington: Department of Conservation.

Whitaker, T., Tocher, M., \& Blair, T. (2002). Conservation of lizards in Otago Conservancy. Department of Conservation, Wellington.

Wickes C, Crouchley D, and Maxwell JM (2009). Takahe (Porphorio hochstetteri) recovery plan 2007 -2012. Department of Conservation, Wellington, NZ.

Williams, E. S., Thome, E. T., Appel, M. J., \& Belitsky, D. W. (1988). Canine distemper in black-footed ferrets (Mustela nigripes) from Wyoming. Journal of Wildlife Diseases, 24(3), 385-398.

Willis, C., Wilson, T., Greenwood, M., \& Ward, L. (2002). Pet reptiles associated with a case of salmonellosis in an infant were carrying multiple strains of Salmonella. Journal of clinical microbiology, 40(12), 4802-4803.

Woodroffe, R. (1999). Managing disease threats to wild mammals. Animal Conservation, 2(03), 185-193.

Woodford, M. H. (1993). International disease implications for wildlife translocation. Journal of Zoo and Wildlife Medicine, 265-270.

Worthy, T. H., \& Holdaway, R. N. (2002). The lost world of the moa: prehistoric life of New Zealand. Indiana University Press. 
